\begin{tabular}{|l|l|}
\hline $\begin{array}{l}\text { 2. To: (Receiving organization) } \\
\text { TWRS FDS Project Office }\end{array}$ & $\begin{array}{l}\text { 3. From: (originating Organization) } \\
\text { TWRS CFO }\end{array}$ \\
\hline $\begin{array}{l}\text { 5. Proj./Prog./Dept./Div.: } \\
\text { Tank Waste Remediation } \\
\text { System J7200 }\end{array}$ & $\begin{array}{l}\text { 6. Cog. Engr.: } \\
\text { K. L. Pearce }\end{array}$ \\
\hline $\begin{array}{l}\text { 8. Originator Remarks: } \\
\text { Transmittal of FY 98 Performance Expectation P]an to FDH for } \\
\text { Review and Approval }\end{array}$
\end{tabular}

11. Receiver Remarks: 11A. Design Baseline Document? $*$ Yes
4. Related EDT No.:

N/A

7. Purchase Order No.:

$$
\text { N/A }
$$

9. Equip./Component No.:

$$
N / A
$$

10. Systen/8ldg./Facility:

$$
N / A
$$

12. Major Assm. Dwg. No.: N/A

13. Permit/Permit Application No.: $N / A$

14. Required Response Date:

$$
1 / 5 / 98
$$

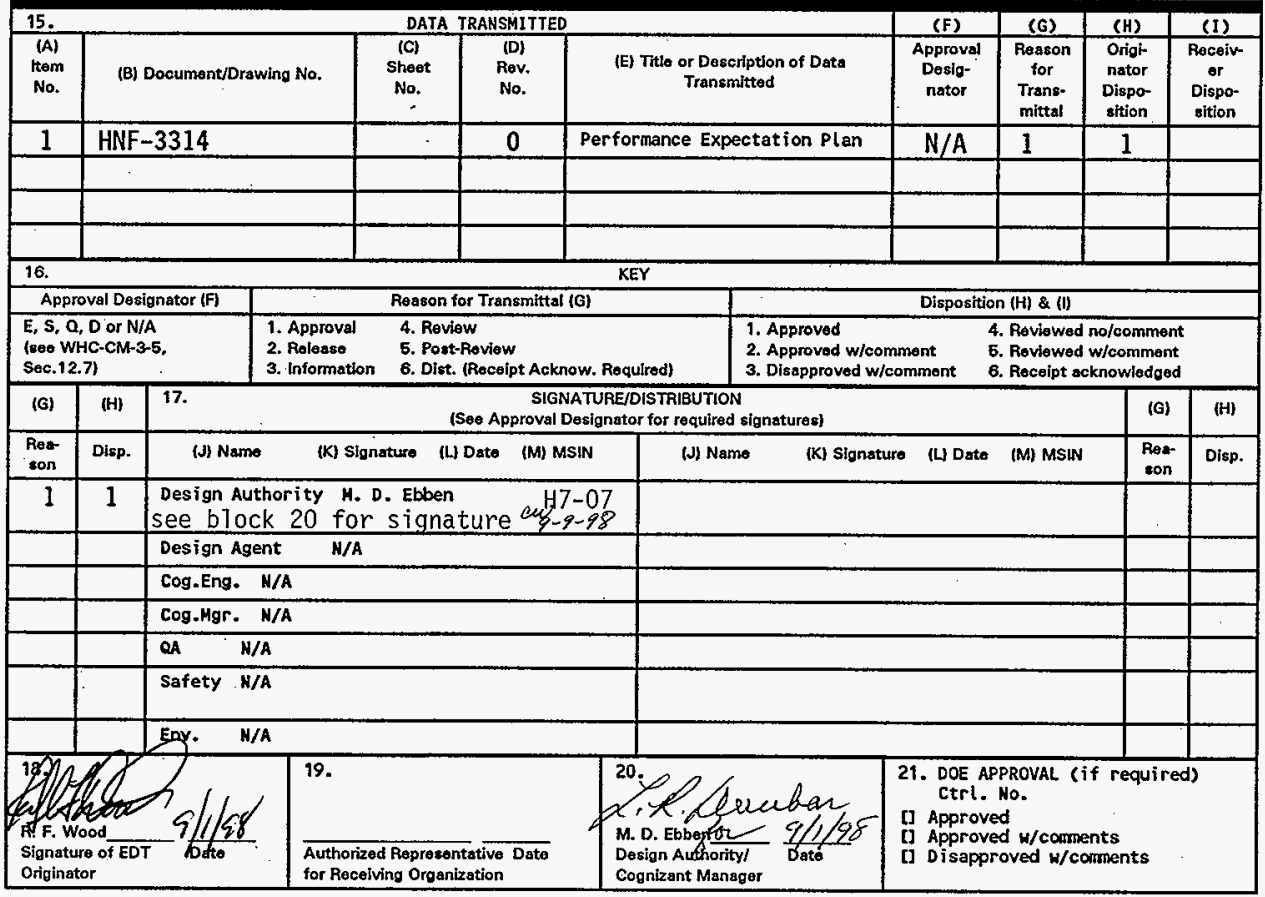


HNF-3314, Rev. 0

\title{
Performance Expectation Plan
}

\author{
P. E. Ray \\ Lockheed Martin Hanford Company, Richland, WA 99352 \\ U.S. Department of Energy Contract DE-AC06-96RL13200
EDT/ECN: EDT-625595
Org Code: 72000
B\&R Code: EW3130010
UC: 2030
Charge Code: 37200 Task Order: HJ215000
Totail Pages: $1 / 5 \cdot \mathrm{cm} 9-4-98$

Key Words: Performance Expectation P1an

Abstract: This document outlines the significant accomplishments of fiscal year 1998 for the Tank Waste Remediation System (TWRS) Project Hanford Management Contract (PHMC) team. Opportunities for improvement to better meet some performance expectations have been identified. The PHMC has performed at an excellent level in administration of Teadership, planning, and technical direction. The contractor has met and made notable improvement of attaining customer satisfaction in mission execution. This document includes the team's recommendation that the PHMC TWRS Performance Expectation P1an evaluation rating for fiscal year 1998 be an Excellent.

TRADEMARK DISCLAIMER. Reference herein to any specific comercial product, process, or service by trade name, trademark, manufacturer, or ótherwise, does not necessarily constitute or imply its endorsement, recommendation, or favoring by the United States Government or any agency thereof or its contractors or subcontractors.

Printed in the United States of America. To obtain copies of this document, contact: Document Control Services, P.O. Box 950, Mailstop H6-08, Richland WA 99352, Phone (509) 372-2420; Fax (509) 376-4989.
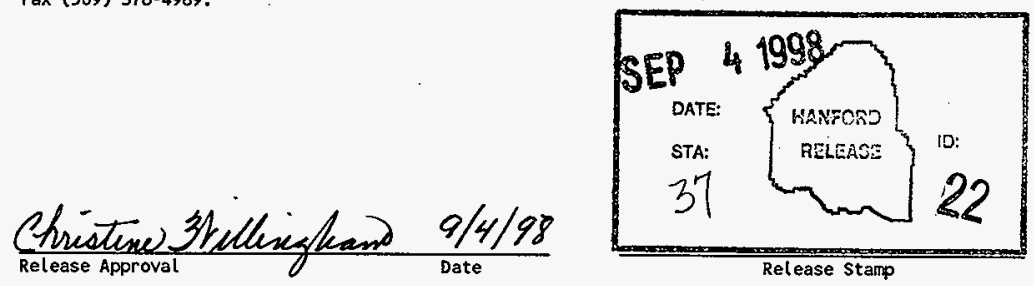


\section{Project Hanford Management Contract Tank Waste Remediation System Performance Expectation Plan Self-Evaluation - Fiscal Year 1998}

Ralph Wood

Lockheed Martin Hanford Corporation

Date Published

September 1998

Prepared for the U.S. Department of Energy Funding Source

FLUOR DANUEL HANFORD, INC.

P.O. Box 1000

Richland, Washington

Hanford Management and Integration Contractor for the

U.S. Department of Energy under Contract DE-AC06-96RL.13200 


\section{HNF-3314 REV 0}

This page intentionally left blank. 
HNF-3314 REV 0

\section{THIS PAGE INTENTIONALLY} LEFT BLANK 
HNF-3314 REV 0

This page intentionally left blank. 


\section{TANK WASTE REMEDIATION SYSTEM FISCAL YEAR 1998 PERFORMANCE EXPECTATION PLAN}

\section{EXECUTIVE SUMMARY}

Fiscal year 1998 has been a challenging year for the Tank Waste Remediation System (TWRS) Project Hanford Management Contract (PHMC) team. There have been significant accomplishments that are molding the Hanford Site into mission success. Opportunities for improvement to better meet some performance expectations were identified and became the subject of mitigation plans which were executed with positive results.

\section{SIGNIFICANT ACCOMPLISHMENTS}

\section{Tank Waste Operations}

- Received SUBTAP comment that "a sustained vigorous safety program is paying off and should be continued"

- Achieved 1,000,000 hours worked without a lost workday case

- Decreased the rate and frequency of reportable occurrences

- Completed Phases I and II of Standard Requirements Identification Document (S/RIDs) process for identifying customer requirements related to personal monitoring and hazardous waste operations and emergency response

- Successfully supported the customer for M-41 milestones which helped the customer mitigate potential legal action by Washington Department of Ecology (WDOE)

- Received a rating of "2" (Meets Expectations) for environmental compliance from the Facility Evaluation Board

- Conducted the Hanford Site's first-ever Maintenance Planner Qualification Program that all maintenance planners complete

- Obtained a $60 \%$ reduction in the size of work packages

- Implemented a facility excellence program at tank farms and greatly improved the tank farms housekeeping functions.

\section{Safety Project}

- Made improvements to the Plant Review Committee to optimize the technical review process on critical TWRS issues and concerns; improvements allowed work to continue with close management involvement

- Completed extensive technical and communication efforts to support early closure of DNFSB 93-5 and DNFSB 92.4.

- Developed a strategy to close a criticality safety issue earlier than planned

- Resolved Tier II concerns related to the TWRS final safety analysis report

- Established a strategy for unexplained crust growth in tank 101-SY

- Initiated an Unreviewed Safety Question (USQ) process bulletin to communicate USQ process information to screeners and evaluators, shift personnel, and the 


\section{HNF-33I4 REV 0}

Plant Review Committee. The bulletin provides sound guidance, qualification information, and timely notification of changes to the approved TWRS Authorization Basis.

\section{Characterization Project}

- Qualified the rotary mode core sampling system for operations in flammable gas atmospheres; the amount of sample recovery in that sampling system was significantly increased

- Recovered the rotary mode core sampling system schedule even when numerous delays were encountered

\section{Tank Waste Disposal}

- Congress, WDOE, Hanford Advisory Board, and Stakeholders supported authorization to proceed with privatization, demonstrating confidence in TWRS's readiness to proceed

- Exceeded customer expectations with readiness to proceed day-to-day support and documentation; this effort fully supported the customer's most recent privatization initiative/negotiations with privatization contractor British Nuclear Fuel

- Provided a well-planned and executed Project W-465 performance assessment

- Continued progress with the Hanford Tanks Initiative that includes breaking new ground with innovative ways of involving the private sector in development of viable single-shell tank retrieval solutions

\section{Management Systems}

- Baseline management and funds control have been maintained throughout periods of instability

- Continued efficiencies in contract scope performance; cost and schedule performance for fiscal year 1998 is projected to be approximately negative $3 \%$ schedule variance and positive $6 \%$ cost variance

- PHMC has completed $85 \%$ of controlled milestones as planned; it is projected that $91 \%$ of fiscal year 1998 controlled milestones will be met as planned; it should be noted that the missed milestones are tied to Tri-Party Agreement renegotiations as a result of single-shell tank stabilization issues and U.S. Department of Energy, Richland Operations Office-approved delays

- Completed the Notice of Construction Permit Applications for Rotary Mode Core Sampling, SX-104, and Project W-030, to meet project deadlines; also on schedule to meet the RCRA Part B permit application in June 1999; on track in developing an environmental compliance program that is to be completed by the end of fiscal year 1998 . 


\section{HNF-3314 REV 0}

The major accomplishments listed above, coupled with the attached PEP Evaluation clearly demonstrate that the management and integration concept as set forth in this contract has been successful.

Specifically, FDH and its main subcontractors have demonstrated the technical excellence and focused commitment to achieve the stated TWRS mission success while providing the Government a fair price with best-in-class personnel and technology.

The technical quality of products increased during fiscal year 1998 while significant efficiencies were achieved, as evidenced by Performance Expectation MGR1.1.1. Fiscal year 1998 accomplishments reflect PHMC leadership excellence in executing the TWRS mission in accordance with contract specifications.

It should be noted that during the past six months, the team continued to focus on the mission and that focus is reflected in the team's accomplishments. The TWRS PHMC team has excelled in the following significant areas.

- Strengthened the planning process through the utilization of the mission logic, which drives the TBR planning process; this process provided TWRS the first exhaustive planning basis of this mission which includes evaluation of risks, assumptions, requirements, resources constraints

- Provided timely response to the customer while mitigating potential legal action by the Washington State Department of Ecology surrounding the milestones for stabilization of single-shell tank

- Provided timely information to the customer in support of privatization negotiations

- Completed extensive technical and communication efforts to support early closure of DNFSB 93-5 and DNFSB 92.4.

- Made the Authorization Basis more accessible to applicable personnel for increased awareness

In summary, Fluor Daniel Hanford and its main subcontractors have performed to an Excellent level. They have provided the planning, technical direction, and leadership to meet the mission objectives and exceed the customer's expectations.

The team therefore recommends that the PHMC TWRS Performance Expectation Plan evaluation rating for fiscal year 1998 be awarded as an Excellent. 
HNF-3314 REV 0

This page intentionally left blank. 


\section{TABLE OF CONTENTS}

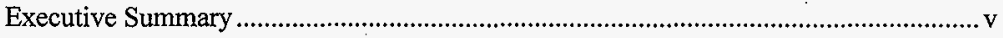

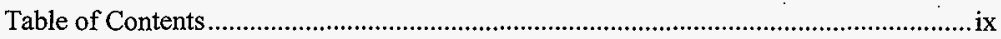

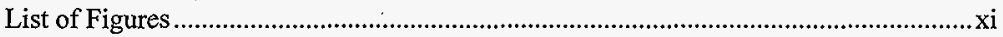

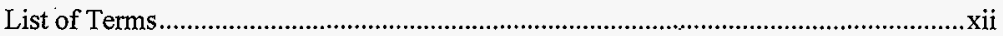

4.1 Safety and Health Performance Expectation ........................................4.1-1

4.2 Environmental Performance Expectation ............................................4.2-1

4.3 Training/Quality of Workforce Expectation..........................................3-1

4.4 Performance of Work (Conduct of Operations and Maintenance, Radiological Control) Expectation

4.4.1 Encourage employee involvement in the development of program goals, objectives, and performance measures ......................................4.4.1-1

4.4.2 Continue reporting and indexing conduct of operations events.........4.4.2-1

4.5 Schedule Performance Expectation ……........................................... 4.5-1

4.6 Cost Performance Expectation........................................................... 4.6-1

4.7 Rework Required Expectation ..........................................................4.7-1

4.8 Energy Efficiency and Pollution Prevention Performance

Expectation ...................................................................................... $4.8-1$

4.9 Project Management Performance Expectation.....................................4.9-1

4.10 Overall Performance Expectation .....................................................4.10-1

4.11 Significant Evaluation Items

4.11.1 Expectation: Issue a DOE reviewed and approved report on flammable gas issues in double-contained receiver tanks by June 23, 1998

4.11.2 Expectation: By July 1, 1998, provide U.S. Department of Energy (Richland Operations) - Tank Waste Remediation System with an interim stabilization program restructuring recommendation. 


\section{HNF-3314 REV 0}

4.11.3 Expectation: By May 15, 1998, provide the proposed RL "Implementing Actions" list for RL approval

4.11.4 Expectation: By August 30, 1998, prepare and issue an annual operational waste volume projection report..

4.11.5 Expectation: By February 17; 1998, award tank C-106 heel removal contract

4.11.6 Expectation: By September 30, 1998, demonstrate 30-day single-shell tank emergency pumping preparation capability

4.11.7 Expectation: By August 30, 1998, complete installation and signal acquisition of Tank Monitoring and Control Systems on five tanks in AW Tank Farm (AW-102, AW-103, AW-104, AW-105, and AW-106) 


\section{LIST OF FIGURES}

Figure 4.1-1 Employees Celebrating 1 Million Hours Without a Lost Workday Injury

Figure 4.1-2 TWRS Total OSHA Recordable Case Rate. $4.1-5$

Figure 4.1-3 RMCS Truck $4.1-7$

Figure 4.3-1 Containment Course Training Equipment . 4.3-4

Figure 4.3-2 Sample Qualification Card.

Figure 4.4.1-1 FEP Monthly Status Chart

Figure 4.4.1-2 First "10" on a TWRS Facility.

Figure 4.4.1-3 VPP License to Succeed Program.

Figure 4.4.2-1 Monthly Frequency of Violation of Procedures

Figure 4.4.2-2 Monthly CONOPS Event Index.

Figure 4.5-1 Performance Indicators Through July 1998 4.5-3

Figure 4.5-2 TBR Package Preparation Process Flow Chart.

Figure 4.9-1

W-464 Storage Facility

Figure 4.9-2. John Wagoner Speaking at the W-058 Completion Ceremony ...4.9-13

Figure 4.9-3 W-058 Cross-Site Transfer System Piping $4.9-14$

Figure 4.10-1 Letter, WDOE to John Wagoner, RL, no subject, dated November 19, 1997. $4.10-5$

Figure 4.10-2 Letter, J. T. Conway, DNFSB, to F. F. Pena, DOE-HQ, no subject, dated November 12, 1997. $4.10-8$ 


\section{LIST OF TERMS}

$\begin{array}{ll}\text { ATP } & \text { Acceptance Test Plan } \\ \text { BCR } & \text { Baseline Change Request } \\ \text { CFR } & \text { Code of Federal Regulations } \\ \text { CPO } & \text { Characterization Program Office } \\ \text { DNFSB } & \text { Defense Nuclear Facilities Safety Board } \\ \text { DOE } & \text { U.S. Department of Energy } \\ \text { DOE-HQ } & \text { U.S. Department of Energy - Headquarters } \\ \text { DOE/RL } & \text { U.S. Department of Energy Richland Operations Office } \\ \text { DOH } & \text { U.S. Department of Health } \\ \text { DST } & \text { Double-Shell Tank } \\ \text { ECN } & \text { Engineering Change Notice } \\ \text { EWP } & \text { Enhanced Work Planning } \\ \text { FDH } & \text { Fluor Daniel Hanford, Incorporated } \\ \text { FDHPO } & \text { Fluor Daniel Hanford Project Office } \\ \text { FY } & \text { Fiscal Year } \\ \text { HNF } & \text { Hanford Nuclear Facility } \\ \text { HSTD } & \text { Hanford Site Technical Database } \\ \text { HTI-LDUA } & \text { Hanford Tanks Initiative - Light Duty Utility Arm } \\ \text { ICD } & \text { Interface Control Document } \\ \text { IHLW } & \text { Interim High Level Waste } \\ \text { ILAW } & \text { Interim Low Activity Waste } \\ \text { LMHC } & \text { Lockheed Martin Hanford Corporation } \\ \text { LO/TO } & \text { Lockout / Tagout } \\ \text { MYWP } & \text { Multi-Year Work Plan } \\ \text { NEPA } & \text { National Environmental Protection Agency } \\ \text { NOC } & \text { Net Open Commitments } \\ \text { OJT } & \text { On-the-Job Training } \\ \text { OSHA } & \text { Occupational Safety and Health Administration } \\ \text { OWVP } & \text { Operational Waste Volume Projections } \\ \text { PA } & \text { Performance Agreement } \\ \text { PHMC } & \text { Project Hanford Management Contract } \\ \text { PNNL } & \text { Pacific Northwest National Laboratory } \\ \text { PROCINFO } & \text { Procedure Information } \\ \text { RL } & \text { Richland Operations Office (DoE) } \\ \text { RMCS } & \text { Rotary Mode Core Sampling } \\ \text { RTP } & \text { Readiness-To-Proceed } \\ \text { SAD } & \text { Safety Assessment Document } \\ \text { SC } & \text { Safety Class } \\ \text { SCD } & \text { Steam Condensate Discharge } \\ \text { SNF } & \text { Special Nuclear Fuel } \\ \text { S/RID } & \text { Standard Requirements Identification Document } \\ \text { SRTC } & \text { Savannah River Technology Center } \\ \text { SST } & \text { Single-Shell Tank } \\ & \end{array}$




$\begin{array}{ll}\text { SV } & \text { Safety Valve } \\ \text { SWP } & \text { Saltwell Pumping } \\ \text { TAP } & \text { Tanks Advisory Panel } \\ \text { TBD } & \text { To Be Determined } \\ \text { TMACS } & \text { Tank Monitoring and Control Systems } \\ \text { TMX } & \text { Training Matrix } \\ \text { TPA } & \text { Tri-Party Agreement (Hanford Federal Facility Agreement and } \\ & \text { Consent Order) } \\ \text { TWINS } & \text { Tank Waste Information Network System } \\ \text { TWR } & \text { Tank Waste Remediation } \\ \text { TWRS } & \text { Tank Waste Remediation System } \\ \text { TWRS BIO } & \text { Tank Waste Remediation System Basis for Interim Operation } \\ \text { USQ } & \text { Unreviewed Safety Question } \\ \text { WDOE } & \text { Washington State Department of Ecology (use Ecology) } \\ \text { WIRD } & \text { Waste Information Requirements Document . } \\ \text { WMH } & \text { Waste Management Hanford }\end{array}$


HNF-3314 REV 0

This page intentionally left blank. 


\section{PHMC - Tank Waste Remediation System Performance Expectation Plan Self-Evaluation - Fiscal Year 1998}

4.1 Safety and Health Performance Expectation: Ensure that potential radioactive and hazardous material exposures to members of the public and work force are as low as reasonably achievable, and that Tank Waste Remediation System (TWRS) facilities operated by the Contractor have the capabilities, consistent with the types of operations conducted, to monitor routine and nonroutine releases. Ensure the Authorization Basis accurately reflects TWRS operations and activities. Make readily accessible to U.S. Department of Energy (DOE), current versions of Authorization Basis documentation. Complete verification of controls that were retained from the interim safety basis to the basis for interim operation as defined in DOE/RL-97-72, Safety Evaluation Report Amendment.

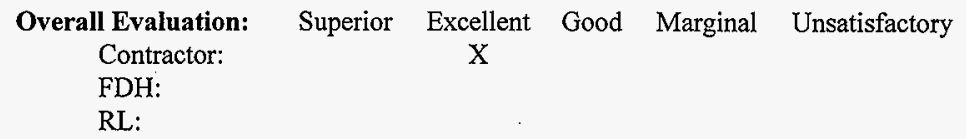

\begin{tabular}{|l|c|c|l|l|}
\hline \multicolumn{1}{|c|}{ Measurement Criteria } & Met & $\begin{array}{l}\text { Not } \\
\text { Met }\end{array}$ & \multicolumn{1}{c|}{ Examples } & Documented Evidence \\
\hline $\begin{array}{l}\text { Monitoring systems meet } \\
\text { national standards and DOE } \\
\text { requirements }\end{array}$ & X & $\begin{array}{l}\text { TWRS completed the Phase I and II standard } \\
\text { requirements identification document (S/RID) } \\
\text { process for identifying DOE requirements } \\
\text { related to (1) personal monitoring system } \\
\text { requirements and (2) hazardous waste } \\
\text { operations and emergency response. The } \\
\text { TWRS health and safety plan (HASP) meets } \\
\text { 29 Code of Federal Regulations } \\
\text { (CFR) 1910.120 safety and health standard } \\
\text { requirements and is consistent with National }\end{array}$ & $\begin{array}{l}\text { Recent external and internal } \\
\text { assesment examples of TWRS } \\
\text { and DOE requirements and } \\
\text { performance expectation plan } \\
\text { criteria are as follows: }\end{array}$ \\
\hline
\end{tabular}




\begin{tabular}{|c|c|c|c|c|}
\hline Measurement Criteria & Met & $\begin{array}{l}\text { Not } \\
\text { Met }\end{array}$ & $\begin{array}{c}\text { Examples } \\
\end{array}$ & Documented Evidence \\
\hline $\begin{array}{l}\text { Monitoring systems meet } \\
\text { national standards and DOE } \\
\text { requirements (continued) }\end{array}$ & $\mathrm{X}$ & & $\begin{array}{l}\text { Institute of Occupational/Safety \& Health } \\
\text { (NIOSH), Occupational Safety \& Health } \\
\text { Administration (OSHA), United States Coast } \\
\text { Guard (USCG), and Environmental Protection } \\
\text { Agency requirements; Occupational Safety and } \\
\text { Health Guidance Manual for Hazardous Waste } \\
\text { Site Activities (NIOSH 1985); and Project } \\
\text { Hanford management policies and procedures. } \\
\text { The most stringent requirements apply when } \\
\text { differences in governing regulations or policies } \\
\text { exist. } \\
\text { Tank waste operations comply with } \\
29 \text { CFR } 1910.120 \text {, for a Resource Conservation } \\
\text { and Recovery Act of } 1976 \text { (RCRA) facility. } \\
\text { Respiratory protection zones are established } \\
\text { and updated. Precautions over and above } \\
\text { requirements of } 29 \text { CFR } 1910.120 \text { (p) } \\
\text { requirements are implemented at the direction } \\
\text { of LMHC whenever feasible to protect } \\
\text { employee safety and health. } \\
\text { Following a May } 1998 \text { presentation on the } \\
\text { status of TWRS Environmental, Safety \& } \\
\text { Health programs, the Safety and Health } \\
\text { SUBTAP commented that Industrial Hygiene } \\
\text { Program figures for lost workday and OSHA } \\
\text { recordable case rates indicate "that a sustained } \\
\text { vigorous safety program is paying off and } \\
\text { should be continued" and that the Safety } \\
\text { Improvement Program "is set on a correct path }\end{array}$ & $\begin{array}{l}\text { Letter, C.S. Abrams, Chairman, } \\
\text { Worker Safety \& Health Sub-Panel, } \\
\text { to M. Royack, DOE, Nineteenth } \\
\text { Meeting of the Subtap for Worker } \\
\text { Safety and Health (WSH) - May } \\
\text { I8-21, 1998, dated June 4, 1998. }\end{array}$ \\
\hline
\end{tabular}




\begin{tabular}{|c|c|c|c|c|}
\hline Measurement Criteria & Met & $\begin{array}{l}\text { Not } \\
\text { Met }\end{array}$ & $\begin{array}{c}\text { Examples } \\
\end{array}$ & Documented Evidence \\
\hline $\begin{array}{l}\text { Monitoring systems meet } \\
\text { national standards and DOE } \\
\text { requirements (continued) }\end{array}$ & $\mathrm{X}$ & & $\begin{array}{l}\text { and (SUBTAP) approves its vigor and } \\
\text { aspirations." Figure } 4.7-1 \text { shows employees } \\
\text { celebrating } 1 \text { million hours without a lost } \\
\text { workday injury. Figure } 4.1-2 \text { shows the TWRS } \\
\text { Total OSHA Recordable Case Rate. } \\
\text { A recent Facility Evaluation Board (FEB) } \\
\text { evaluation of double-shell tanks (DSTs) } \\
\text { resulted in an overall evaluation of "2" (Meets } \\
\text { Expectations) for occupational safety and } \\
\text { health performance (1 is best possible score on } \\
\text { a 1-to-5 scale). } \\
\text { PHMC calibrates and documents calibration of } \\
\text { monitoring equipment to national standard and } \\
\text { manufacturer specifications. } \\
\text { Monitoring of toxic vapors and combustible } \\
\text { gases is performed by the TWRS Industrial } \\
\text { Hygiene group in accordance with the Tank } \\
\text { Farms Health and Safety Plan } \\
\text { (HNF-SD-WM-HSP-002) and the TWRS BIO } \\
\text { (HNF-SD-WM-BIO-001). These documents } \\
\text { have been verified to be in compliance with } \\
\text { national standards and DOE requirements and } \\
\text { have been reviewed and agreed to by DOE. } \\
\text { PHMC completed a compressed gas self }\end{array}$ & $\begin{array}{l}\text { G.W. Grier and G.A. Harvey, FDH, } \\
\text { to M.P. Delozier, LMHC, Facility } \\
\text { Evaluation Board Report, Double } \\
\text { Shell Tanks And Characterization } \\
\text { Project, dated April 30, } 1998 . \\
\text { Results are maintained and } \\
\text { retrievable through the Industrial } \\
\text { Hygiene Monitoring Programs } \\
\text { Coordinator (E. R. Hewitt). } \\
\text { Monitoring information is recorded } \\
\text { and maintained in TWRS Industrial } \\
\text { Hygiene files. }\end{array}$ \\
\hline
\end{tabular}


HNF-3314 REV 0

Figure 4.1-1 Employees Celebrating 1 Million Hours Without a Lost Workday Injury

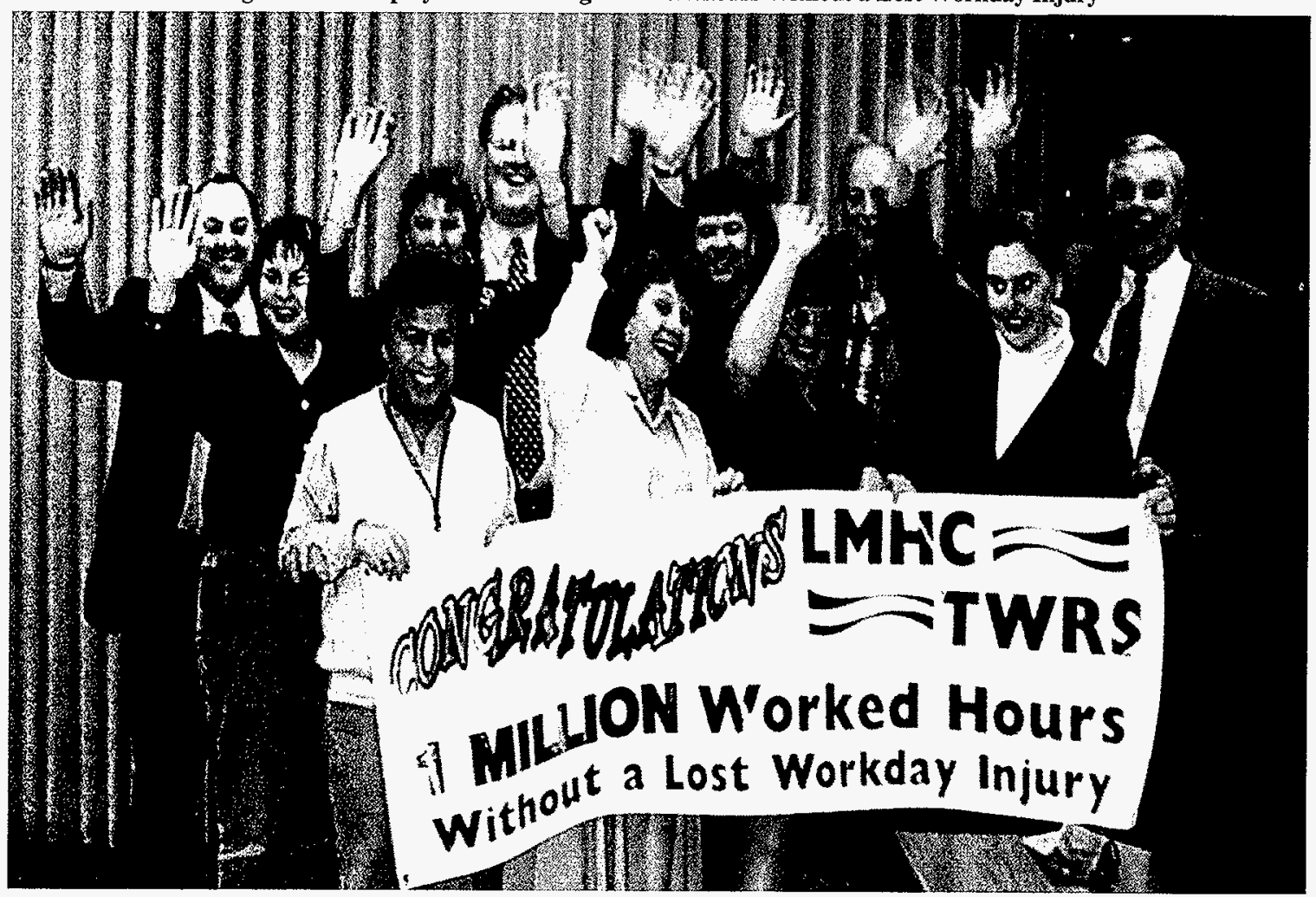




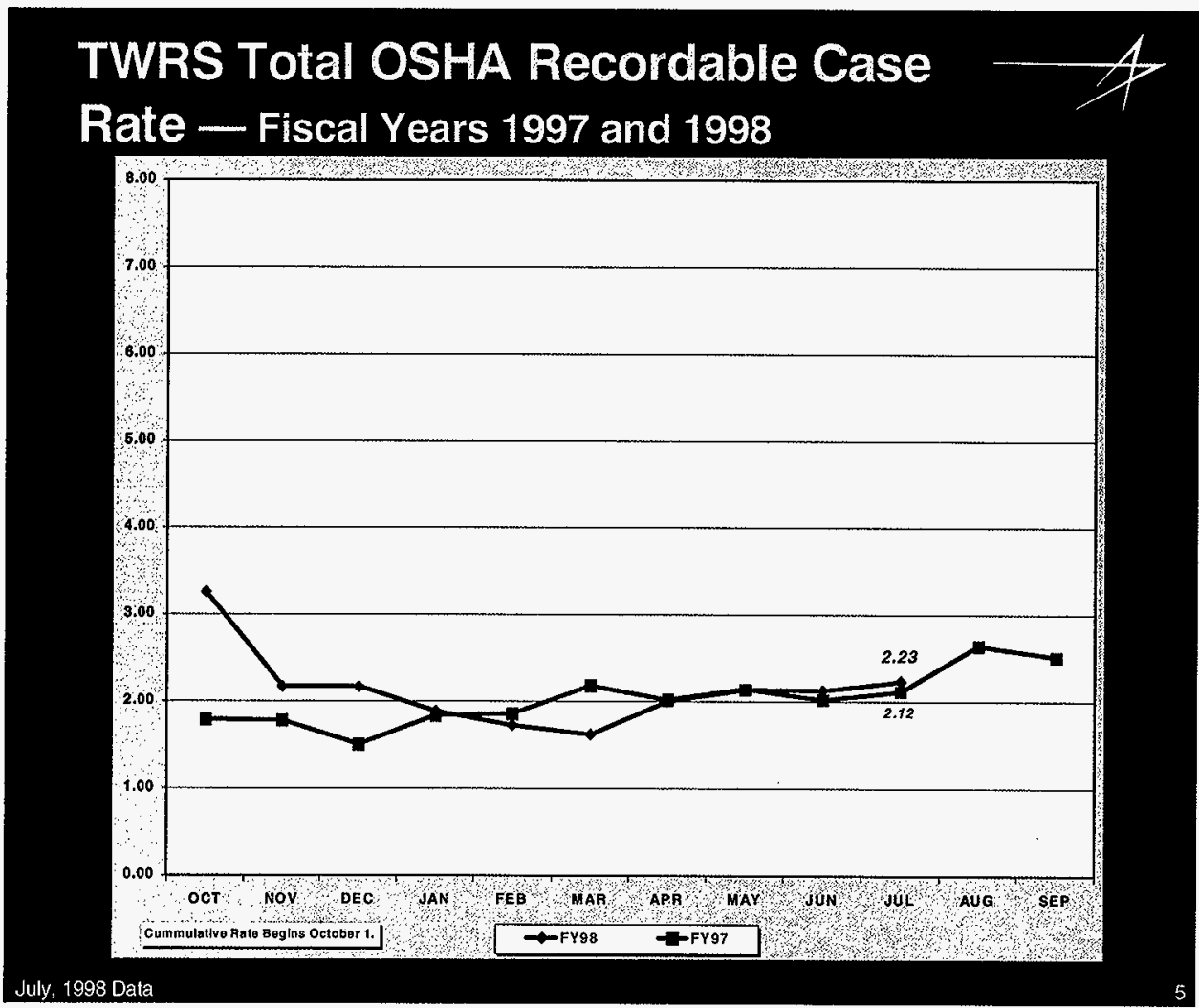




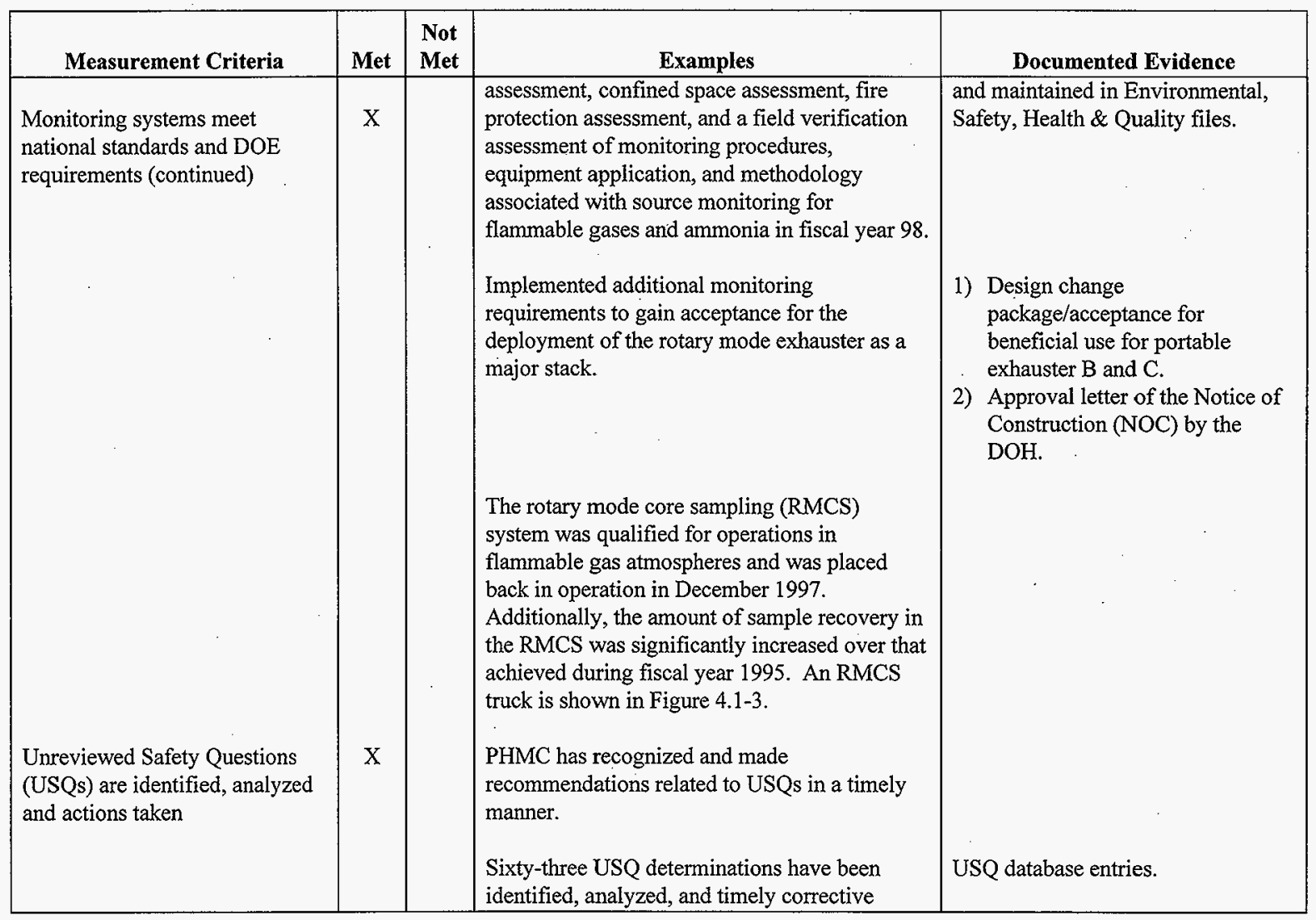


HNF-3314 REV 0

Figure 4.1-3 RMCS Truck

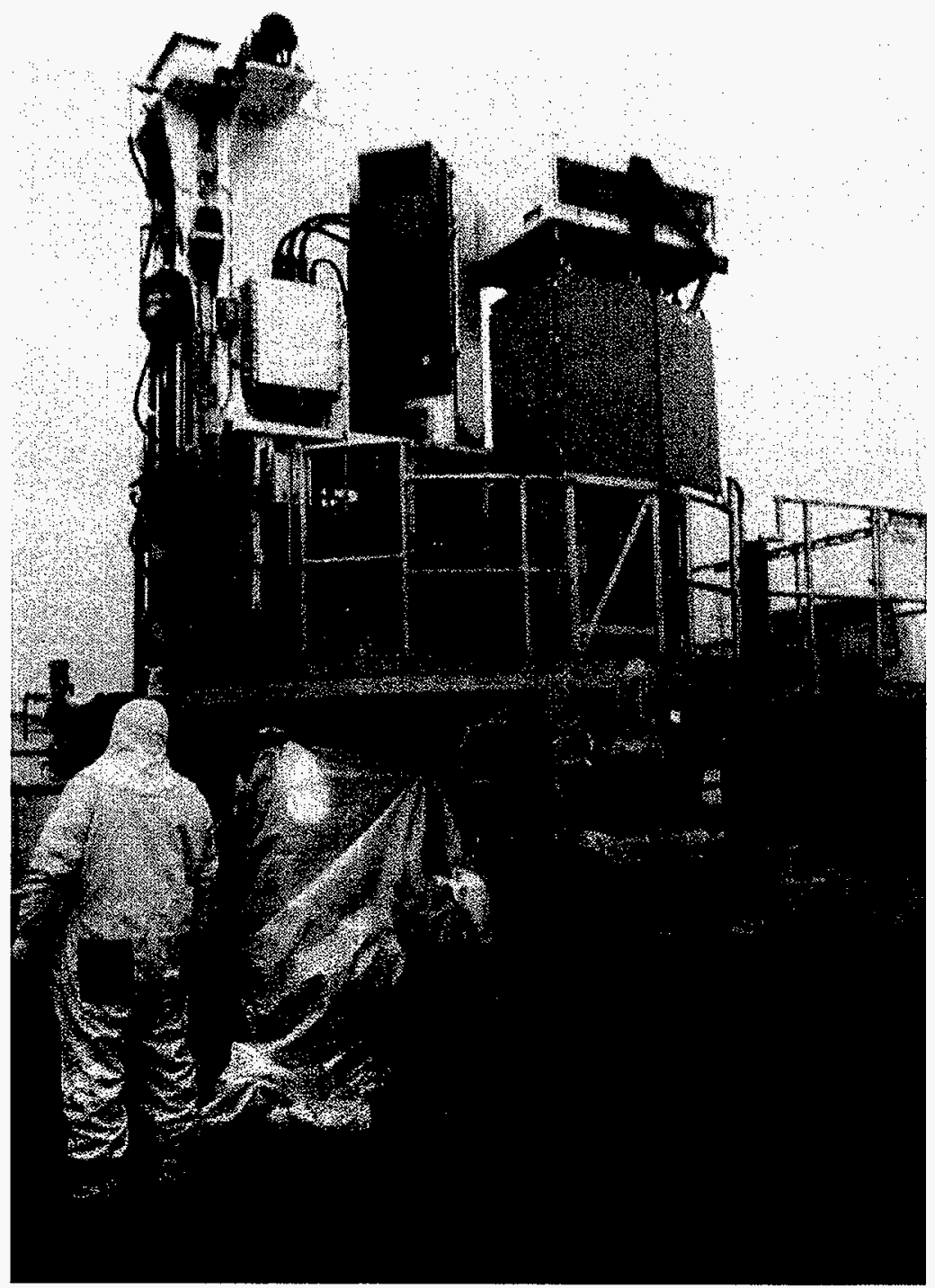




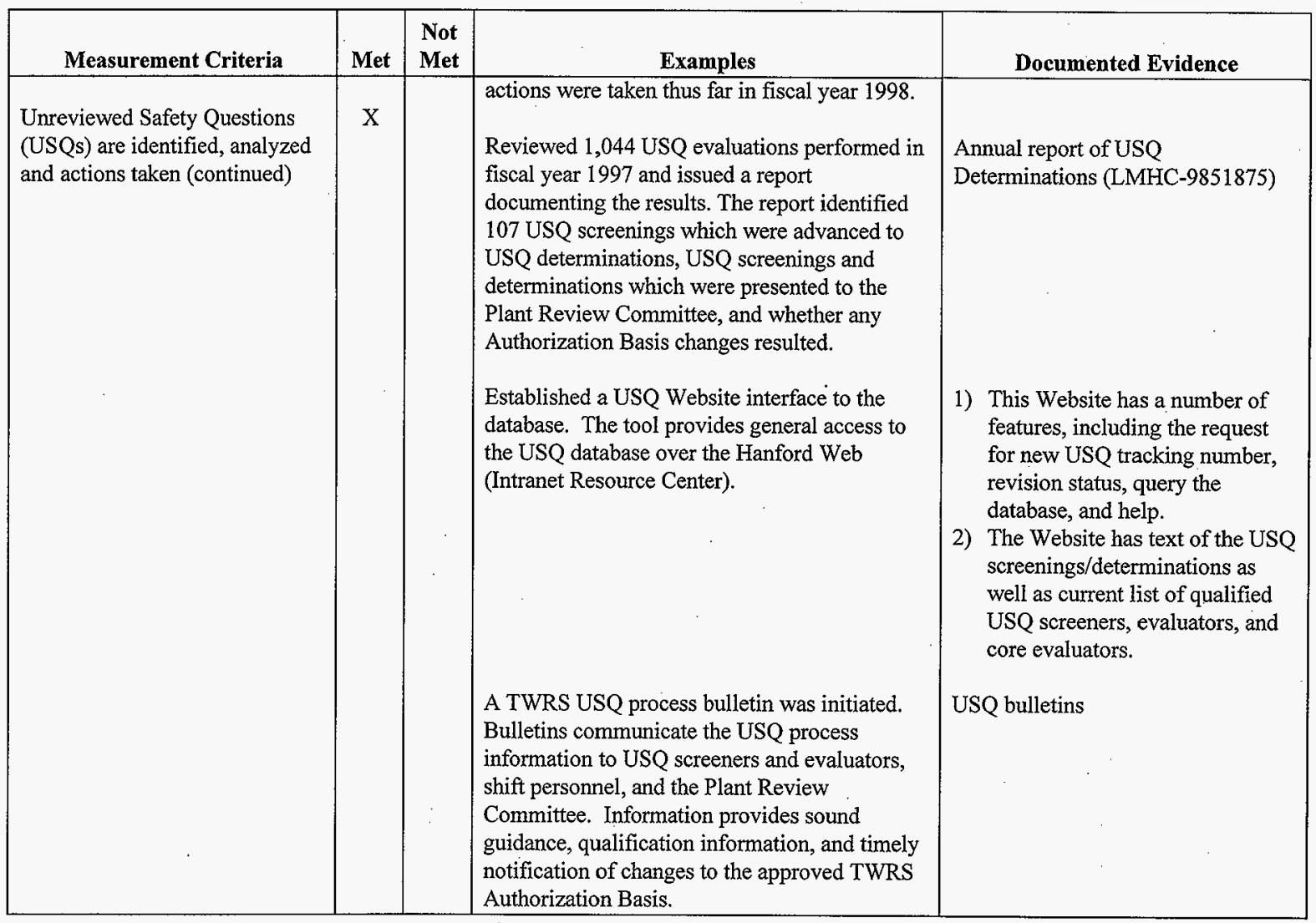


HNF-3314 REV 0

\begin{tabular}{|c|c|c|c|c|}
\hline Measurement Criteria & Met & $\begin{array}{l}\text { Not } \\
\text { Met }\end{array}$ & Examples & Documented Evidence \\
\hline $\begin{array}{l}\text { Unreviewed Safety Questions } \\
\text { (USQs) are identified, analyzed } \\
\text { and actions taken (continued) }\end{array}$ & $\mathrm{X}$ & & $\begin{array}{l}\text { A comprehensive assessment of the USQ } \\
\text { process was conducted by the Authorization } \\
\text { Basis Management and Implementation Group } \\
\text { to determine whether the TWRS USQ process } \\
\text { was being effectively implemented as required } \\
\text { by HNF-IP-0842, Volume IV, Engineering, } \\
\text { Section } 5.1 \text {, "Plant Review Committee." } \\
\text { Results indicated the process is firmly in place } \\
\text { and the assessment team observed significant } \\
\text { improvement. } \\
\text { The USQ associated with the waste level } \\
\text { growth in tank } 241-S Y-101 \text { is being effectively } \\
\text { and efficiently handled to minimize stakeholder } \\
\text { impacts. A task team was assembled, a path } \\
\text { forward developed, and two void fraction } \\
\text { instrument readings taken and reported. }\end{array}$ & $\begin{array}{l}\text { 1) Interoffice memo } \\
\text { \#2N150-98-012, M.C. Brady to } \\
\text { M.P. DeLozier, Unreviewed } \\
\text { Safety Question Assessment, } \\
\text { dated August } 98 \text {. } \\
\text { 2) RL comment that the Contractor } \\
\text { has recognized and made } \\
\text { recommendations related to } \\
\text { USQs in a timely manner. } \\
\\
\text { 1) Task Team Report on the Level } \\
\text { Growth Issue in } 241-S Y-101 \text {, } \\
\text { February 23, 1998, transmitted } \\
\text { by Safety Issue Resolution } \\
\text { Project interoffice memo, G.D. } \\
\text { Johnson, February } 27,1998 . \\
\text { 2) Formal briefings were provided. } \\
\text { by the task team to Project } \\
\text { Hanford Management Contract } \\
\text { (PHMC) senior management and } \\
\text { DOE, Richland Operations } \\
\text { Office (RL). } \\
\text { 3) HNF-2772, Tank 24I-SY-101, } \\
\text { Level Confirmation Report, Rev. } \\
\text { 0, released June 5, 1998. } \\
\text { 4) Letter, A.M. Umek, Fluor } \\
\text { Daniel Hanford, Inc. (FDH), to } \\
\text { J.E. Kinzer, RL, Contract } \\
\text { Number DE-AC06-96RL13200, }\end{array}$ \\
\hline
\end{tabular}


HNF-3314 REV 0

\begin{tabular}{|c|c|c|c|c|}
\hline Measurement Criteria & Met & $\begin{array}{l}\text { Not } \\
\text { Met }\end{array}$ & Examples & Documented Evidence \\
\hline $\begin{array}{l}\text { Unreviewed Safety Questions } \\
\text { (USQs) are identified, analyzed } \\
\text { and actions taken (continued) }\end{array}$ & $\mathrm{X}$ & & 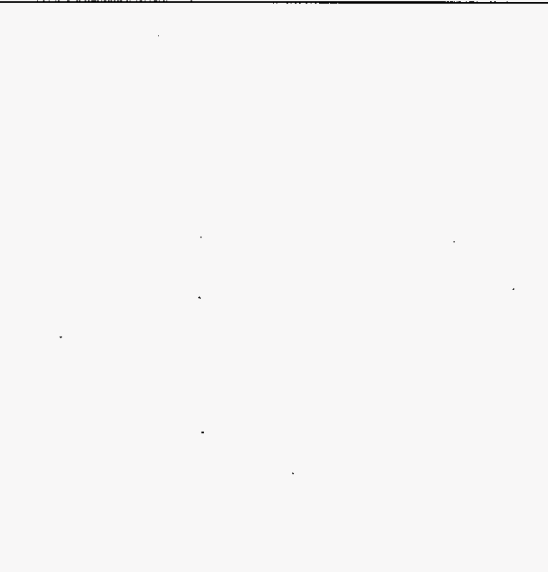 & $\begin{array}{l}\text { Plan for Addressing the Level } \\
\text { Growth Issue in Tank } \\
\text { 241-SY-101, FDH-9851287, } \\
\text { dated March 25, 1998. } \\
\text { 5) Letter of Instruction for Void } \\
\text { Fraction Measurements in Tank } \\
\text { 241-SY-101, Lockheed Martin } \\
\text { Hanford Corp (LMHC) } \\
\text { interoffice memo } \\
\text { 7A120-98-002, N.E. Wilkins. } \\
\text { 6) Pacific Northwest National } \\
\text { Laboratory (PNNL) report, Void } \\
\text { Fraction Instrument Data for } \\
\text { SY-101, Riser 11B, June 29 and } \\
\text { July 22, 1998, Quick Look } \\
\text { Report, TWS98.61, dated July } \\
\text { 28, 1998. }\end{array}$ \\
\hline $\begin{array}{l}\text { Quality and availability of } \\
\text { Authorization Basis } \\
\text { documentation }\end{array}$ & $\mathrm{X}$ & & $\begin{array}{l}\text { Tank dome loading issues were evaluated and } \\
\text { structural concerns quantified. This extensive } \\
\text { effort allowed for continued operation within } \\
\text { the tank farms and allowed for the associated } \\
\text { USQ to be closed. } \\
\text { Knowledge of the TWRS Authorization Basis } \\
\text { by cognizant engineers and facility operators } \\
\text { has improved. Three Qual Cards for cognizant } \\
\text { engineering functions within the Nuclear Safety } \\
\text { \& Licensing organization were developed; }\end{array}$ & $\begin{array}{l}\text { HNF-2733, Rational for the Closure } \\
\text { of the Soil Density Unreviewed } \\
\text { Safety Question and Recommended } \\
\text { Structural Analyses Improvements } \\
\text { for the TWRS Underground Storage } \\
\text { Facilities, Rev. 0, dated June 12, } \\
1998 . \\
\text { 1) Qual Cards for safety analyses } \\
\text { engineers. } \\
\text { 2) Qual Cards for licensing } \\
\text { engineers. } \\
\text { 3) Qual Cards for Authorization }\end{array}$ \\
\hline
\end{tabular}


HNF-3314 REV 0

\begin{tabular}{|c|c|c|c|c|}
\hline Measurement Criteria & Met & $\begin{array}{l}\text { Not } \\
\text { Met }\end{array}$ & Examples & Documented Evidence \\
\hline $\begin{array}{l}\text { Quality and availability of } \\
\text { Authorization Basis } \\
\text { documentation (continued) }\end{array}$ & $\mathrm{X}$ & & $\begin{array}{l}\text { these Qual Cards established training } \\
\text { requirements for individuals with key position } \\
\text { responsibilities. } \\
\text { The Tier II concerns related to the facility } \\
\text { safety analysis reports were quickly and } \\
\text { professionally resolved. } \\
\text { Six Authorization Basis satellite stations were } \\
\text { created to provide Authorization Basis } \\
\text { documents at key locations around TWRS. } \\
\text { This information has been effectively } \\
\text { maintained and has passed } 13 \text { consecutive } \\
\text { audits without deficiencies. }\end{array}$ & $\begin{array}{l}\text { Basis engineers. } \\
\text { Facility safety analysis reports Tier } \\
\text { II review } \\
\text { 1) Documents are located with the } \\
\text { single-shell tank (SST) and } \\
\text { double-shell tank (DST) shift } \\
\text { offices, in the Nuclear Safety } \\
\text { and Licensing, Characterization } \\
\text { Project office, and in RL Safety } \\
\text { and Characterization Division } \\
\text { offices. The sixth set is retained } \\
\text { in Building } 2750 \mathrm{E} \text {, room C116. } \\
\text { 2) Because of the importance and } \\
\text { the substantial use of these } \\
\text { documents they are periodically } \\
\text { surveyed to check revision status } \\
\text { and physical condition. As } \\
\text { evidenced by the last } 13 \text { straight } \\
\text { surveillances with no } \\
\text { discrepancies, these documents } \\
\text { are being properly maintained. } \\
\text { 3) Copies of the audits are } \\
\text { available in the Tank } \\
\text { Characterization and Safety } \\
\text { Resource Center, } \\
\text { Building } 2750 \mathrm{E} \text {, Room C116, }\end{array}$ \\
\hline
\end{tabular}




\begin{tabular}{|c|c|c|c|c|}
\hline Measurement Criteria & Met & $\begin{array}{l}\text { Not } \\
\text { Met }\end{array}$ & Examples & Documented Evidence \\
\hline $\begin{array}{l}\text { Quality and availability of } \\
\text { Authorization Basis } \\
\text { documentation (continued) }\end{array}$ & $\mathrm{X}$ & . & $\begin{array}{l}\text { An Authorization Basis library was established. } \\
\text { The library is a collection of documents related } \\
\text { to the development and implementation of the } \\
\text { TWRS Authorization Basis. In addition to the } \\
\text { documents identified as part of the } \\
\text { Authorization Basis, the collection includes } \\
\text { non-Authorization Basis documents that are } \\
\text { referenced by Authorization Basis documents } \\
\text { and documents that were developed for or that } \\
\text { otherwise support implementation of the } \\
\text { Authorization Basis. } \\
\text { The TWRS Authorization Basis Status Report, } \\
\text { HNF-2503, Rev.0, was completed and sent to } \\
\text { FDH on April } 29,1998 \text {. This report identifies } \\
\text { facilities and the corresponding Authorization } \\
\text { Basis applicable to each facility. Also, the } \\
\text { report identified upgrade tasks along with a } \\
\text { prioritization and preliminary cost estimate for } \\
\text { each facility upgrade. } \\
\text { Rapid turn-around on Authorization Basis }\end{array}$ & $\begin{array}{l}\text { and will be supplied on request. } \\
\text { Established as documented in } \\
\text { LMHC Interoffice memo } \\
\text { 2N150-98-013. To minimize the } \\
\text { cost of setting up the library, the } \\
\text { following collections of documents } \\
\text { were incorporated as part of the } \\
\text { library: } \\
\text { - Environmental Library - } \\
\text { 2750E Building, Room A-125 } \\
\text { - FSAR Reference Library - } \\
\text { Federal Building, Room 301-L } \\
\text { - Authorization Basis } \\
\text { Requirements Management } \\
\text { Interface } \\
\text { - Procedure Information } \\
\text { (PROCINFO) } \\
\text { - Records Management } \\
\text { Information System (RMIS). } \\
\text { Letter from M.A. Payne, LMHC, to } \\
\text { A.M. Umek, FDH, LHMC 9853746, } \\
\text { dated April 29, 1998. }\end{array}$ \\
\hline
\end{tabular}


HNF-3314 REV 0

\begin{tabular}{|l|c|c|l|l|}
\hline Measurement Criteria & Met & $\begin{array}{c}\text { Not } \\
\text { Met }\end{array}$ & \multicolumn{1}{|c|}{ Examples } & \multicolumn{1}{c|}{ Documented Evidence } \\
\hline $\begin{array}{l}\text { Assurance that the controls were } \\
\text { retained from the interim safety } \\
\text { basis }\end{array}$ & $\mathrm{X}$ & & $\begin{array}{l}\text { clarifications supported the B Plant facility } \\
\text { closure critical path schedule. Three liquid } \\
\text { waste transfers were accepted while satisfying } \\
\text { TWRS Authorization Basis requirements. }\end{array}$ & $\begin{array}{l}\text { (forwarded message from Kent } \\
\text { Transfer to Tank Farms, dated } \\
8 / 3 / 98 .\end{array}$ \\
\hline
\end{tabular}




\section{HNF-3314 REV 0}

This page intentionally left blank. 


\section{PHMC - Tank Waste Remediation System Performance Expectation Plan Self-Evaluation - Fiscal Year 1998}

4.2 Environmental Performance Expectation: Develop a technical environmental foundation for permit negotiations with federal and state regulatory agencies. Maintain an electronic database of all regulatory requirements to assist in the TWRS compliance assurance program. Integrate all environmental activities for the TWRS program including operations, safety, characterization, retrieval, disposal and privatization programs and projects.

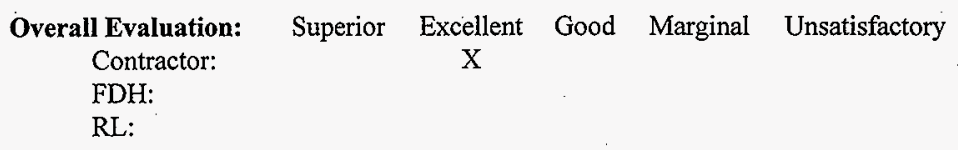

\begin{tabular}{|c|c|c|c|c|}
\hline Measurement Criteria & Met & $\begin{array}{l}\text { Not } \\
\text { Met }\end{array}$ & Examples & Documented Evidence \\
\hline $\begin{array}{l}\text { Regulatory compliance with } \\
\text { laws and regulations }\end{array}$ & $\mathrm{X}$ & & $\begin{array}{l}\text { TWRS Operations, supported by the TWRS } \\
\text { Safety staff, completed the Phase I and } \\
\text { Phase II S/RID process. The S/RID process } \\
\text { identified DOE requirements related to personal } \\
\text { monitoring system requirements and required } \\
\text { hazard characterization requirements related to } \\
\text { hazardous waste operations and emergency } \\
\text { response. A safety and health plan meeting the } \\
29 \text { CFR } 1910.120 \text { safety and health standard } \\
\text { requirements is consistent with National } \\
\text { Institute of Occupational Safety and Health, } \\
\text { United States Coast Guard, and Environmental }\end{array}$ & $\begin{array}{l}\text { TWRS compliance with national } \\
\text { standards and DOE requirements is } \\
\text { documented through an internal and } \\
\text { external assessment process. The } \\
\text { following are recent results of } \\
\text { assessments and evaluations. } \\
\text { Safety and Health SUBTAP, May } \\
\text { 1998. High-level review of TWRS } \\
\text { industrial hygiene programs was } \\
\text { praised by the Safety and Health } \\
\text { SUBTAP conducted in May of } \\
\text { 1998. Facility Evaluation Board }\end{array}$ \\
\hline
\end{tabular}




\begin{tabular}{|c|c|c|c|c|}
\hline Measurement Criteria & Met & $\begin{array}{l}\text { Not } \\
\text { Met }\end{array}$ & Examples & Documented Evidence \\
\hline $\begin{array}{l}\text { Regulatory compliance with } \\
\text { laws and regulations (continued) }\end{array}$ & $\mathrm{X}$ & & $\begin{array}{l}\text { Protection Agency requirements; Occupational } \\
\text { Safety and Health Guidance Manual for } \\
\text { Hazardous Waste Site Activities } \\
\text { (NIOSH 1985); and Project Hanford } \\
\text { management policies and procedures. The } \\
\text { most stringent requirements apply when } \\
\text { differences in governing regulations or policies } \\
\text { exist. Tank farm operations comply with. } \\
29 \text { CFR } 1910.120 \text { for a Resource Conservation } \\
\text { and Recovery Act of I976 facility. Respiratory } \\
\text { protection zones have been established and } \\
\text { updated. Precautions over and above the } \\
\text { requirements of } 29 \text { CFR } 1910.120 \text { (p) have been } \\
\text { implemented at the direction of LMHC } \\
\text { whenever feasible to protect employee safety } \\
\text { and health. } \\
\text {. }\end{array}$ & $\begin{array}{l}\text { comprehensive assessments have } \\
\text { been completed anmually for all tank } \\
\text { farm facilities by the Facility } \\
\text { Evaluation Board. Performance- } \\
\text { based assessment areas include } \\
\text { industrial hygiene and } \\
\text { environmental monitoring systems. } \\
\text { The most recent evaluation resulted } \\
\text { in a score of } 2 \text { (1 being the best } \\
\text { possible score on a 1-to-5 scale) and } \\
\text { a grade of } 3 \text { in the environmental } \\
\text { appraisal. This assessment was } \\
\text { conducted in April 1998. For DOE } \\
\text { field representative audit self- } \\
\text { assessments, LMHC has completed } \\
\text { a compressed gas self-assessment, a } \\
\text { confined space assessment, fire } \\
\text { protection assessments, and a field } \\
\text { verification assessment of } \\
\text { monitoring procedures, equipment } \\
\text { application, and methodology } \\
\text { associated with source monitoring } \\
\text { for flammable gases and ammonia } \\
\text { in fiscal year } 1998 \text {. LMHC } \\
\text { calibrated and documented } \\
\text { calibration of monitoring equipment } \\
\text { to national standards and } \\
\text { manufacturer specifications. } \\
\text { Monitoring results are retrievable } \\
\text { through the Industrial Hygiene } \\
\text { Monitoring Programs coordinator. }\end{array}$ \\
\hline
\end{tabular}


HNF-3314 REV 0

\begin{tabular}{|c|c|c|c|c|}
\hline Measurement Criteria & Met & $\begin{array}{l}\text { Not } \\
\text { Met }\end{array}$ & Examples & Documented Evidence \\
\hline $\begin{array}{l}\text { Regulatory compliance with } \\
\text { laws and regulations (continued) }\end{array}$ & $\mathrm{X}$ & & $\begin{array}{l}\text { The FEB conducted in April } 1998 \text { for double- } \\
\text { shell tanks and characterization gave a rating of } \\
3 \text { (Meets Minimum Requirements) to } \\
\text { environmental protection performance. } \\
\text { Prepared and issued report summarizing } \\
\text { assessment of TWRS characterization and } \\
\text { sampling activities against environmental } \\
\text { regulations and permits. }\end{array}$ & $\begin{array}{l}\text { G.W. Grier and G.A. Harvey, FDH, } \\
\text { to M.P. Delozier, LMHC, Facility } \\
\text { Evaluation Board Report, Double } \\
\text { Shell Tanks and Characterization } \\
\text { Project, dated April 30, 1998. } \\
\text { Performed compliance assessment } \\
\text { of characterization project activities } \\
\text { against the regulatory and } \\
\text { permitting requirements under the } \\
\text { Clean Air Act, Resource } \\
\text { Conservation and Recovery Act } \\
\text { (specifically training, waste } \\
\text { generation, identification, record } \\
\text { keeping, transportation and } \\
\text { manifesting, and storage of } \\
\text { hazardous waste), hazard } \\
\text { communications, and waste } \\
\text { minimization. Supported the } \\
\text { characterization project by } \\
\text { Environmental Protection and } \\
\text { Compliance organization. MYWP } \\
\text { deliverable 4F30B3A } \\
\text { Letter, W.E. Ross, LMHC, to } \\
\text { A.M. Umek, FDH, Subcontract } \\
\text { Number } 80232764-9-K 001- \\
\text { Completion of Milestone } 4 F 30 B 3 A \text {, } \\
\text { LMHC-9855496, June } 29,1998 . \\
\text { FEB-FY98-004-DST/CP, April } 9,\end{array}$ \\
\hline
\end{tabular}


HNF-3314 REV 0

\begin{tabular}{|c|c|c|c|c|}
\hline Measurement Criteria & Met & $\begin{array}{l}\text { Not } \\
\text { Met }\end{array}$ & Examples & Documented Evidence \\
\hline $\begin{array}{l}\text { Regulatory compliance with } \\
\text { laws and regulations (continued) }\end{array}$ & $\mathrm{X}$ & & $\begin{array}{l}\text { regulations. } \\
\text { Operated RMCS exhauster in compliance with } \\
\text { both radioactive air and TAP NOCs. }\end{array}$ & $\begin{array}{l}1998 . \\
\text { Memo, D.H. Schford to } \\
\text { R.S. Popielarczyk, Completion of } \\
\text { Exhauster C Readiness } \\
\text { Preparations, 79513-98-023, dated } \\
\text { May 11, 1998. }\end{array}$ \\
\hline Quality and timeliness & $\mathrm{X}$ & & $\begin{array}{l}\text { TWRS has taken and is involved in several } \\
\text { actions to improve the technical environmental } \\
\text { foundation for permit negotiations with federal } \\
\text { and state regulatory agencies. }\end{array}$ & $\begin{array}{l}\text { Procedure HNF-IP-0842, } \\
\text { Volume VI, Section } 2.1 \text {,"Field } \\
\text { Implementation of Environmental } \\
\text { Notices of Construction for Air } \\
\text { Emission Units Operated by } \\
\text { TWRS," was issued in April 1998, } \\
\text { to formalize the implementation of } \\
\text { radiological/nonradiological air } \\
\text { permit conditions and requirements. } \\
\text { Procedure HNF-IP-0842, } \\
\text { Volume VI, Section } 1.3 \text {, } \\
\text { "Environmental Notification," was } \\
\text { issued in July } 1998 \text { to standardize } \\
\text { TWRS notification requirements to } \\
\text { regulatory agencies. } \\
\text { A partnering program was begun } \\
\text { with Washington State Department } \\
\text { of Health in May } 1998 \text { to improve } \\
\text { air permitting and to address } \\
\text { WDOH concerns. Five topical areas } \\
\text { are being actively worked, with } \\
\text { LMHC having the lead for }\end{array}$ \\
\hline
\end{tabular}


HNF-3314 REV 0

\begin{tabular}{|c|c|c|c|c|}
\hline Measurement Criteria & Met & $\begin{array}{l}\text { Not } \\
\text { Met }\end{array}$ & Examples & Documented Evidence \\
\hline $\begin{array}{l}\text { Quality and timeliness } \\
\text { (continued) }\end{array}$ & $\mathrm{X}$ & & & $\begin{array}{l}\text { management of routine activities. } \\
\text { Participated on the Polychlorinated } \\
\text { Biphenyl Task Force (weekly } \\
\text { meetings initiated August } 1997 \text { and } \\
\text { documented via meeting minutes) to } \\
\text { develop and issue guidance for PCB } \\
\text { waste acceptance. } \\
\text { Initiated use of compliance matrices } \\
\text { in January } 1998 \text { to ensure NOC } \\
\text { requirements are implemented. } \\
\text { Documentation is maintained in } \\
\text { Environmental files. (WDOH is } \\
\text { verbally advocating use of the } \\
\text { compliance matrices sitewide). }\end{array}$ \\
\hline
\end{tabular}




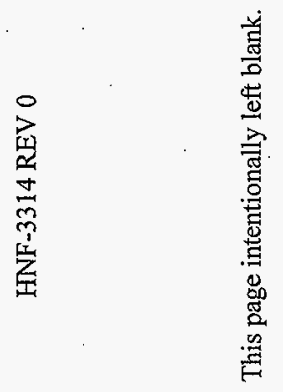




\section{PHMC - Tank Waste Remediation System \\ Performance Expectation Plan \\ Self-Evaluation - Fiscal Year 1998}

4.3 Training/Quality of Workforce Expectation: Continuously develop employees to ensure quality performance from a technically competent, versatile, and diverse work force. Maintain a training and qualification program for TWRS staff per Contractor procedures (WHC-IP-0842) (currently HNF-IP-0842).

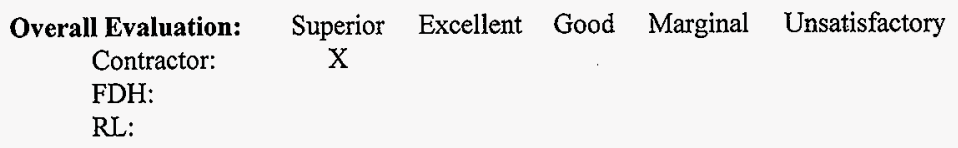

\begin{tabular}{|l|l|l|l|l|}
\hline \multicolumn{1}{|c|}{ Measurement Criteria } & Met & $\begin{array}{l}\text { Not } \\
\text { Met }\end{array}$ & \multicolumn{1}{|c|}{ Supporting Facts } & \multicolumn{1}{|c|}{ Documented Evidence } \\
\hline $\begin{array}{l}\text { Qualification and certification of } \\
\text { technical staff per Contractor } \\
\text { procedures as determined by } \\
\text { training records }\end{array}$ & $\mathrm{X}$ & & $\begin{array}{l}\text { TWRS has defined the technical staff positions } \\
\text { in the training implementation matrix per DOE } \\
\text { Order 5480.20A, approved January 5, 1998, as } \\
\text { cognizant engineers, design authorities, quality } \\
\text { assurance engineers, environmental } \\
\text { professionals, and safety professionals. Even } \\
\text { though DOE Order 5480.20A does not require } \\
\text { any type of formal qualification, TWRS has } \\
\text { developed formal qualifications for each of the } \\
\text { technical staff positions. All technical staff } \\
\text { personnel, with formal signature authority, have } \\
\text { completed their respective qualifications } \\
\text { according to the TWRS Administrative }\end{array}$ & $\begin{array}{l}\text { The } \\
\text { personnel have their respective } \\
\text { qualifications on file and their } \\
\text { TMXs, except for safety } \\
\text { professionals who qualify by } \\
\text { completing HNF-IP-0030, } \\
\text { Section SAF-1.2, reflect the } \\
\text { respective qualification course } \\
\text { numbers as follows: } \\
\text { - Cognizant engineers, \#350860 } \\
\text { Design authorities, \#350865 } \\
\text { Quality Assurance engineers, } \\
\text { \#350885 }\end{array}$ \\
\hline
\end{tabular}


HNF-3314 REV 0

\begin{tabular}{|c|c|c|c|c|}
\hline Measurement Criteria & Met & $\begin{array}{l}\text { Not } \\
\text { Met }\end{array}$ & Supporting Facts & Documented Evidence \\
\hline $\begin{array}{l}\text { Qualification and certification of } \\
\text { technical staff per Contractor } \\
\text { procedures as determined by } \\
\text { training records (continued) }\end{array}$ & $\mathrm{X}$ & & $\begin{array}{l}\text { Procedures Manual, HNF-IP-0842, Volume III, } \\
\text { "Training," Section } 10.3 \text {, "Technical Staff } \\
\text { Qualification Program Description." } \\
\text { TWRS training provides qualification training } \\
\text { to operators in } 18 \text { distinct areas. These } \\
\text { qualifications have been analyzed, designed, } \\
\text { developed, implemented, and evaluated using } \\
\text { the systematic approach to training as required } \\
\text { by DOE Order } 5480.20 A . \text { The program } \\
\text { description in HNF-IP-0842, Volume III, } \\
\text { Section } 10.5 \text { describes the qualification process } \\
\text { for each qualification. TWRS has also in this } \\
\text { past year implemented operator training outside } \\
\text { of the } 18 \text { distinct areas listed in the operator } \\
\text { training program description. Examples are } \\
\text { W-030, W-058, and more recently W-320. The } \\
\text { lessons learned from W-030 and W-058 have } \\
\text { been incorporated into Project W-320 to make } \\
\text { it a more successful project. TWRS } \\
\text { successfully completed the independent/DOE } \\
\text { operational readiness review on W-030 and the } \\
\text { independent/DOE RA on W-058. The } \\
\text { independent W-320 operational readiness } \\
\text { review is in progress at this time. } \\
\text { HNF-IP-0842, Volume III, Section } 10.6 \text {, } \\
\text { "Maintenance Training Program," was revised } \\
\text { in June } 1998 \text { to reflect changes in the training } \\
\text { implementation matrix which was approved by } \\
\text { RL during the second quarter of fiscal year } 98 \text {. }\end{array}$ & $\begin{array}{l}\text { Environmental professionals, } \\
\text { \#350875 } \\
\text { Safety Professionals complete } \\
\text { HNF-IP-0030, Section SAF-1.2. } \\
\text { TWRS maintains an active list of } \\
\text { qualified operations staff on the } \\
\text { PROCINFO computer database that } \\
\text { is accessible to anyone connected to } \\
\text { the Hanford Intranet. Training also } \\
\text { maintains a master program file on } \\
\text { each of the operator qualifications. } \\
\text { The master program file includes } \\
\text { items such as the task list, lesson } \\
\text { guide, associated OJT, and } \\
\text { performance demonstrations. Many } \\
\text { of the operator qualifications have } \\
\text { also been entered into the VISION } \\
\text { training software, which includes } \\
\text { dynamic links between the tasks, } \\
\text { objectives, OJT, and other lists. }\end{array}$ \\
\hline
\end{tabular}


HNF-3314 REV 0

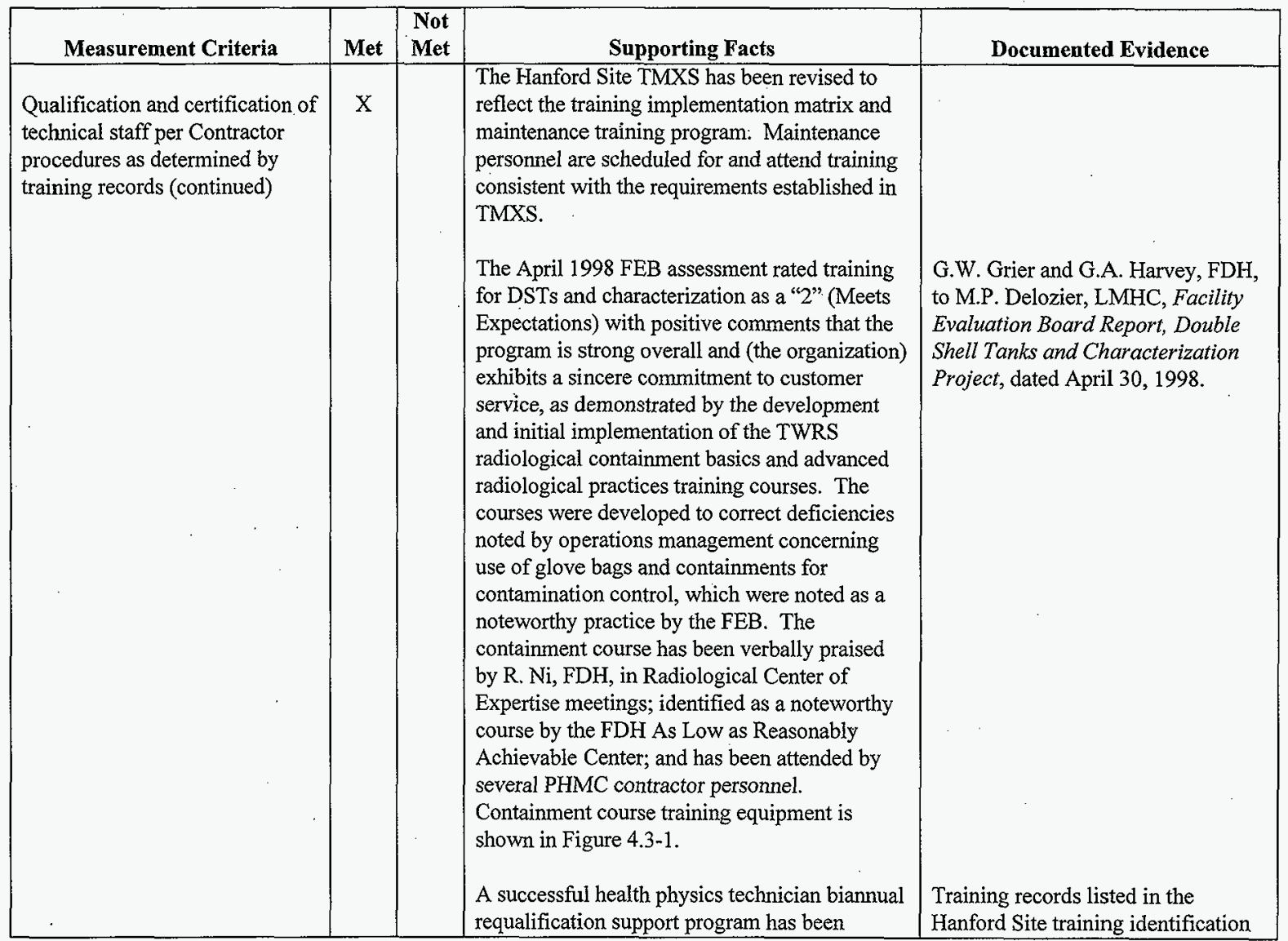




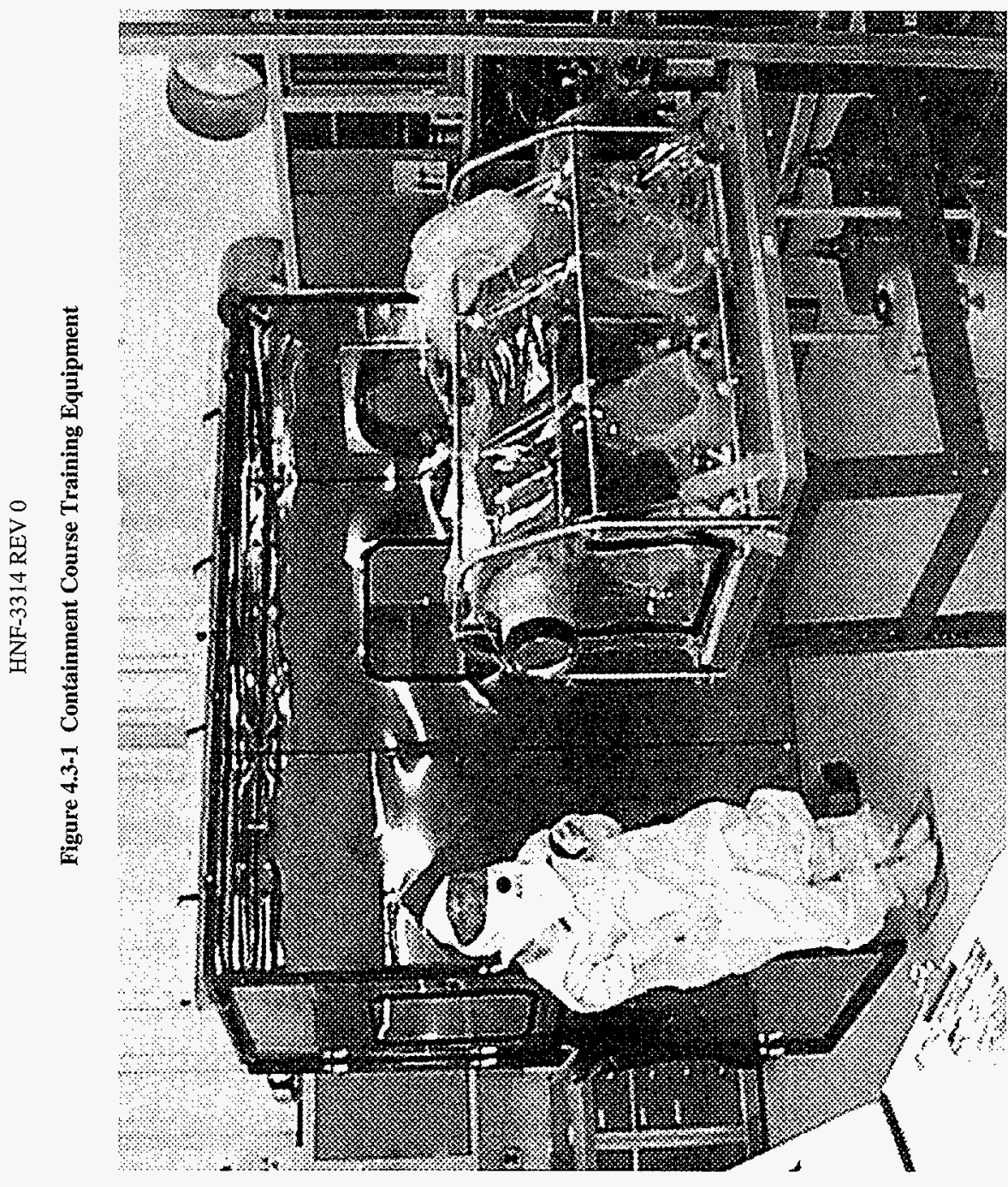

$\stackrel{+}{2}$

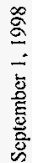




\begin{tabular}{|c|c|c|c|c|}
\hline Measurement Criteria & Met & $\begin{array}{l}\text { Not } \\
\text { Met }\end{array}$ & Supporting Facts & Documented Evidence \\
\hline $\begin{array}{l}\text { Qualification and certification of } \\
\text { technical staff per Contractor } \\
\text { procedures as determined by } \\
\text { training records (continued) }\end{array}$ & $\mathrm{X}$ & & $\begin{array}{l}\text { implemented that has significantly reduced lost } \\
\text { time spent for requalification failures. } \\
\text { Successful written exam participants have } \\
\text { received their oral exams during the same week } \\
\text { (as of August } 1,1998,71 \text { of the } 73 \text { TWRS } \\
\text { personnel have completed full HPT } \\
\text { requalification) and six of nine exam failures } \\
\text { retested and completed requalification within } \\
\text { five days of their original exam. During the } \\
\text { previous requalification cycle, there were more } \\
\text { initial failures and retest/requalification took } \\
\text { over two weeks per person. Due to this TWRS } \\
\text { success, this program is now supporting several } \\
\text { PHMC contractor personnel as they prepare for } \\
\text { HPT requalification or complete retest/ } \\
\text { requalification. }\end{array}$ & and tracking system (TMXS). \\
\hline & & & $\begin{array}{l}\text { Radiological training for lead workers that } \\
\text { supervise radiological work improved field } \\
\text { radiological work practices in SSTs and } \\
\text { contributed to a rating of " } 2 \text { " (Meets } \\
\text { Expectations) for training during the } \\
\text { November } 1997 \text { FEB assessment. } \\
\text { Radiological worker work practice } \\
\text { improvements were identified as "noteworthy } \\
\text { practice" in the November } 1997 \text { FEB } \\
\text { assessment of SSTs. These improvements were } \\
\text { a result of the successful completion of the } \\
\text { TWRS radiological controls improvement plan } \\
\text { (3.0) initiatives related to human factor }\end{array}$ & $\begin{array}{l}\text { G.W. Grier and G.A. Harvey, FDH, } \\
\text { to L.E. Hall, LMHC, Facility } \\
\text { Evaluation Board Report, Single } \\
\text { Shell Tanks and Characterization } \\
\text { Project, dated December 5, } 1997 .\end{array}$ \\
\hline
\end{tabular}


HNF-3314 REV 0

\begin{tabular}{|c|c|c|c|c|}
\hline Measurement Criteria & Met & $\begin{array}{l}\text { Not } \\
\text { Met }\end{array}$ & Supporting Facts & Documented Evidence \\
\hline $\begin{array}{l}\text { Qualification and certification of } \\
\text { technical staff per Contractor } \\
\text { procedures as determined by } \\
\text { training records (continued) }\end{array}$ & $\mathrm{X}$ & & $\begin{array}{l}\text { contributions to radiological deficiencies. } \\
\text { All incumbent (on board as of March 1997) } \\
\text { maintenance planners completed the } \\
\text { maintenance planner qualification program by } \\
\text { November 30, 1997. This action fulfilled a } \\
\text { commitment to the March } 1997 \text { FEB to have all } \\
\text { incumbent planners qualified by the same date. } \\
\text { A sample qualification card is shown in } \\
\text { Figure } 4.3-2 \text {. } \\
\text { A significant effort was expended on the } \\
\text { requalification of cognizant engineers and } \\
\text { design authorities. } \\
\text { Improvements were made to the USQ } \\
\text { qualification program to specify new } \\
\text { qualification requirements for USQ screeners, } \\
\text { evaluators, and core evaluators and to provide } \\
\text { new training material for the USQ training } \\
\text { class. } \\
\text { Qual Cards were developed for criticality safety } \\
\text { specialists and for the criticality safety } \\
\text { representative. In order to complete the } \\
\text { requirements, comprehensive reviews of the } \\
\text { tank farms critically safety program is } \\
\text { necessary. }\end{array}$ & $\begin{array}{l}\text { (1) Letter, R.E. Raymond to M.C. } \\
\text { Skriba, Engineering Signature } \\
\text { Authority - Rev. } 11 \text {, dated July } \\
\text { 22, 1998. } \\
\text { (2) Qual Cards on file with TWRS } \\
\text { training. } \\
\text { HNF-IP-0842 manual } \\
\text { Qual Cards for criticality safety } \\
\text { specialist and criticality. safety } \\
\text { representative }\end{array}$ \\
\hline
\end{tabular}




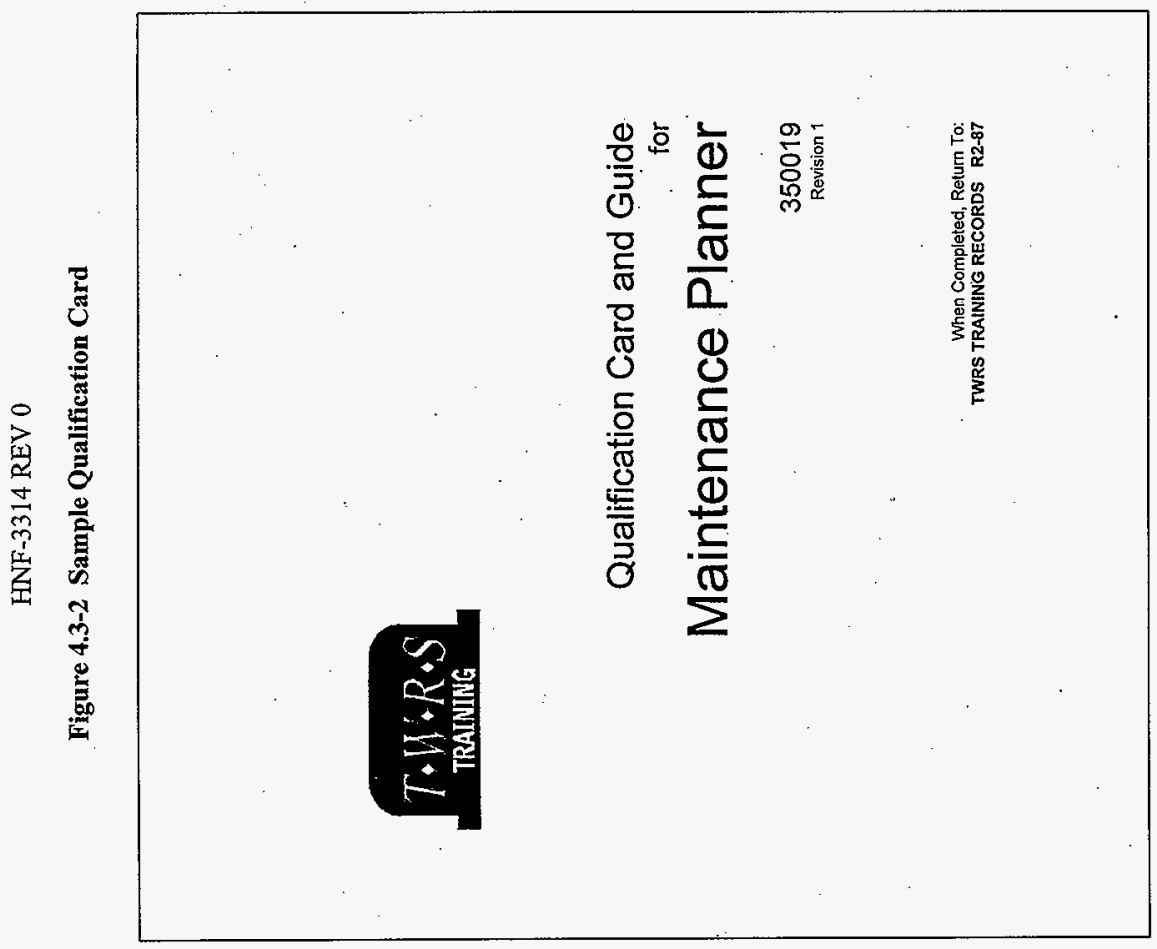




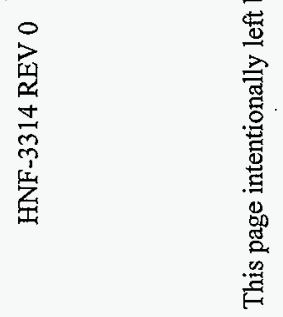




\section{PHMC - Tank Waste Remediation System Performance Expectation Plan Self-Evaluation - Fiscal Year 1998}

\subsection{Performance of Work (Conduct of Operations and Maintenance, Radiological Control) Expectation}

4.4.1 Encourage employee involvement in the development of program goals, objectives, and performance measures and the identification and control of work place hazards. Utilize integrated planning for work processes to ensure consideration and balance of hazards and relative risk.
Overall Evaluation:
Superior
Excellent
$\mathrm{X}$
Good Marginal
Unsatisfactory
Contractor:
FDH:
RL:

\begin{tabular}{|c|c|c|c|c|}
\hline Measurement Criteria & Met & $\begin{array}{l}\text { Not } \\
\text { Met }\end{array}$ & Examples & Documented Evidence \\
\hline $\begin{array}{l}\text { Involvement of people in work } \\
\text { planning }\end{array}$ & $\mathrm{X}$ & & $\begin{array}{l}\text { The Facility Excellence Program (FEP) is } \\
\text { utilized by employees to identify and correct } \\
\text { deficiencies in housekeeping and other areas. } \\
\text { Figure } 4.4 .1-1 \text { is representative of a FEP } \\
\text { monthly status chart. Figure } 4.4 .1-2 \text { shows the } \\
\text { placement of the first " } 10 \text { " on a TWRS facility. } \\
\text { A self-initiated task was taken on by field crews } \\
\text { and engineering to reduce radiation exposure to } \\
\text { workers by improving the sampling equipment } \\
\text { for obtaining liquid grab samples from waste } \\
\text { tanks. }\end{array}$ & $\begin{array}{l}\text { Monthly FEP charts } \\
\text { Acceptance for beneficial use and } \\
\text { engineering test plan for the } 500 \mathrm{ml} \\
\text { bottle sampler. }\end{array}$ \\
\hline
\end{tabular}


Figure 4.4.1-1 FEP Monthly Status Chart

\section{Facility Excellence Program}

\begin{tabular}{|c|c|c|c|c|c|c|c|c|c|c|c|c|c|}
\hline INSPECTION & Juil-97: & Aug:97 & Sop-97: & $00 t-97$ & Nov-97 & Dec-97 & $\operatorname{Jan}-98$ & $F e b-98$ & Mar-98 & Apr-98: & May 98 & Jun-98 & $3+1-98$ \\
\hline FACITIY & RATTHA & FATING & RATENG. & PAFING & -RATIKO- & RATING: & BATHQ & ShTtMG & RATING: & FAnTH & Ratino & RATIKG & RATWO \\
\hline \multicolumn{14}{|l|}{$213-W$} \\
\hline \multicolumn{14}{|l|}{ 244-TX } \\
\hline \multicolumn{14}{|l|}{$242-T$} \\
\hline \multicolumn{14}{|l|}{ U Farm } \\
\hline \multicolumn{14}{|l|}{$272-W A$} \\
\hline \multicolumn{14}{|l|}{$M O-281$} \\
\hline \multicolumn{14}{|l|}{$242-3$} \\
\hline \multicolumn{14}{|l|}{ B/B $\times$ Farms } \\
\hline \multicolumn{14}{|l|}{ T Farm } \\
\hline \multicolumn{14}{|l|}{ Vohicles } \\
\hline \multicolumn{14}{|l|}{$278 . \mathrm{WA}$} \\
\hline \multicolumn{14}{|l|}{ BY Farm } \\
\hline \multicolumn{14}{|l|}{ S/SX Farms } \\
\hline \multicolumn{14}{|l|}{ TXITY Farms } \\
\hline \multicolumn{14}{|l|}{ SY Farm } \\
\hline \multicolumn{14}{|l|}{$M 0.027$} \\
\hline \multicolumn{14}{|l|}{$272-5 / 2707 \cdot 5 x, \cdots$} \\
\hline \multicolumn{14}{|l|}{ 2727-W A/Laydown Yard } \\
\hline \multicolumn{14}{|l|}{ E/W Vent Station/Diversion Boxes } \\
\hline \\
\hline \multirow{2}{*}{\multicolumn{14}{|c|}{+1}} \\
\hline & & & & & & & & & & & & & \\
\hline \\
\hline \\
\hline \\
\hline Total Walkdowns & 3 & 4 & 2 & 4 & 4 & 2 & 5 & 2 & 5 & 5 & 4 & 5 & 4 \\
\hline Single Shell Tanks Overall Rating & 6 & 6 & 6 & 7 & r & 7 & 6 & 7 & 7 & & 6 & 7 & \\
\hline$\cdots$ & & & & & & 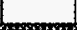 & & & & & & 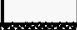 & \\
\hline
\end{tabular}

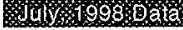


HNF-3314 REV 0

Figure 4.4.1-2 First "10" on a TWRS Facility

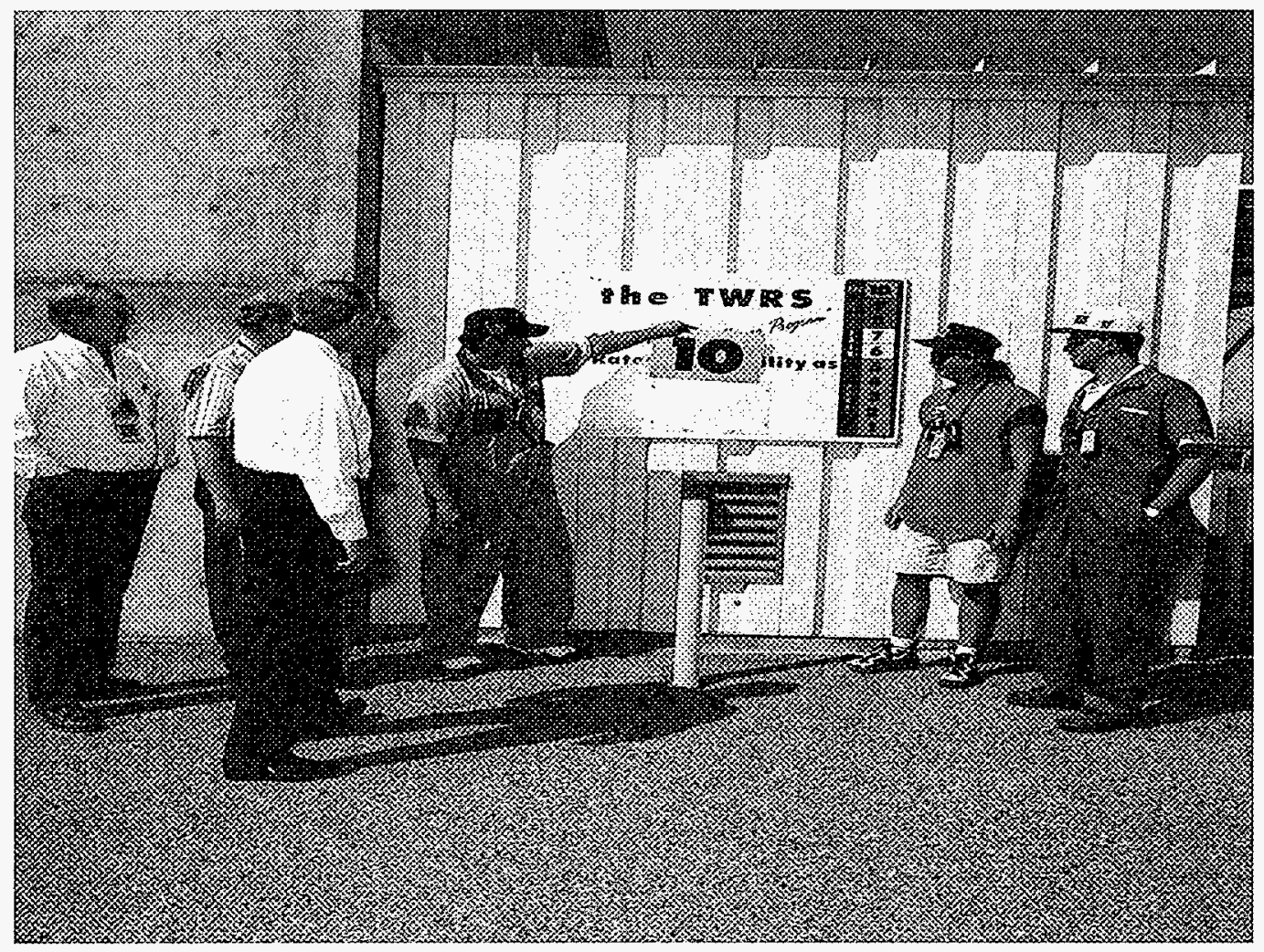




\begin{tabular}{|c|c|c|c|c|}
\hline Measurement Criteria & Met & $\begin{array}{l}\text { Not } \\
\text { Met }\end{array}$ & Examples & Documented Evidence \\
\hline $\begin{array}{l}\text { Involvement of people in work } \\
\text { planning (continued) }\end{array}$ & $\mathrm{X}$ & & $\begin{array}{l}\text { Worked with the regulators on the NOC to } \\
\text { successfully keep the } 702-\mathrm{AZ} \text { ventilation } \\
\text { system operating. } \\
\text { High-priority work tasks for other major } \\
\text { subcontractors on the Hanford Site have been } \\
\text { fully supported. Tasks included } \\
\text { characterization efforts on the Plutonium } \\
\text { Finishing Plant (Z Plant) facility tank Z-361, B } \\
\text { Plant transfers to support facility closure, and K } \\
\text { Basins statistical work and sludge removal. }\end{array}$ & $\begin{array}{l}\text { 1) D.L. Banning, HNF-2176, Tank } \\
\text { 241-Z-361 Waste } \\
\text { Characterization Data Quality } \\
\text { Objective: Headspace Vapor } \\
\text { and Tank Structure," Rev. 0, } \\
\text { issued June 10, 1998. } \\
\text { 2) E-mail, D.G. Baide to } \\
\text { W.E. Bryan (forwarded message } \\
\text { from Kent Smith [B Plant]), } \\
\text { Final B-Plant Transfer to Tank } \\
\text { Farms, dated August 3, 1998. } \\
\text { 3) Memo, L. Jensen and } \\
\text { S.R. Wilmarth to J.P. Sloughter, } \\
\text { Numatec Hanford Corporation, } \\
\text { Statistical Sampling Plan for } \\
\text { Fuel Assemblies in KW Basins, } \\
\text { 7A120-98-009, dated March 12, } \\
\text { 1998. } \\
\text { 4) Memo, L. Jensen and } \\
\text { S.R. Wilmarth to } \\
\text { J.R. Frederickson, DE\&S } \\
\text { Hanford, Inc., Selecting Multiple } \\
\text { Canister Overpacks for } \\
\text { Monitoring Based on Tolerance } \\
\text { Limits and Probability } \\
\text { Distributions, 7A120-98-029, }\end{array}$ \\
\hline
\end{tabular}


HNF-3314 REV 0

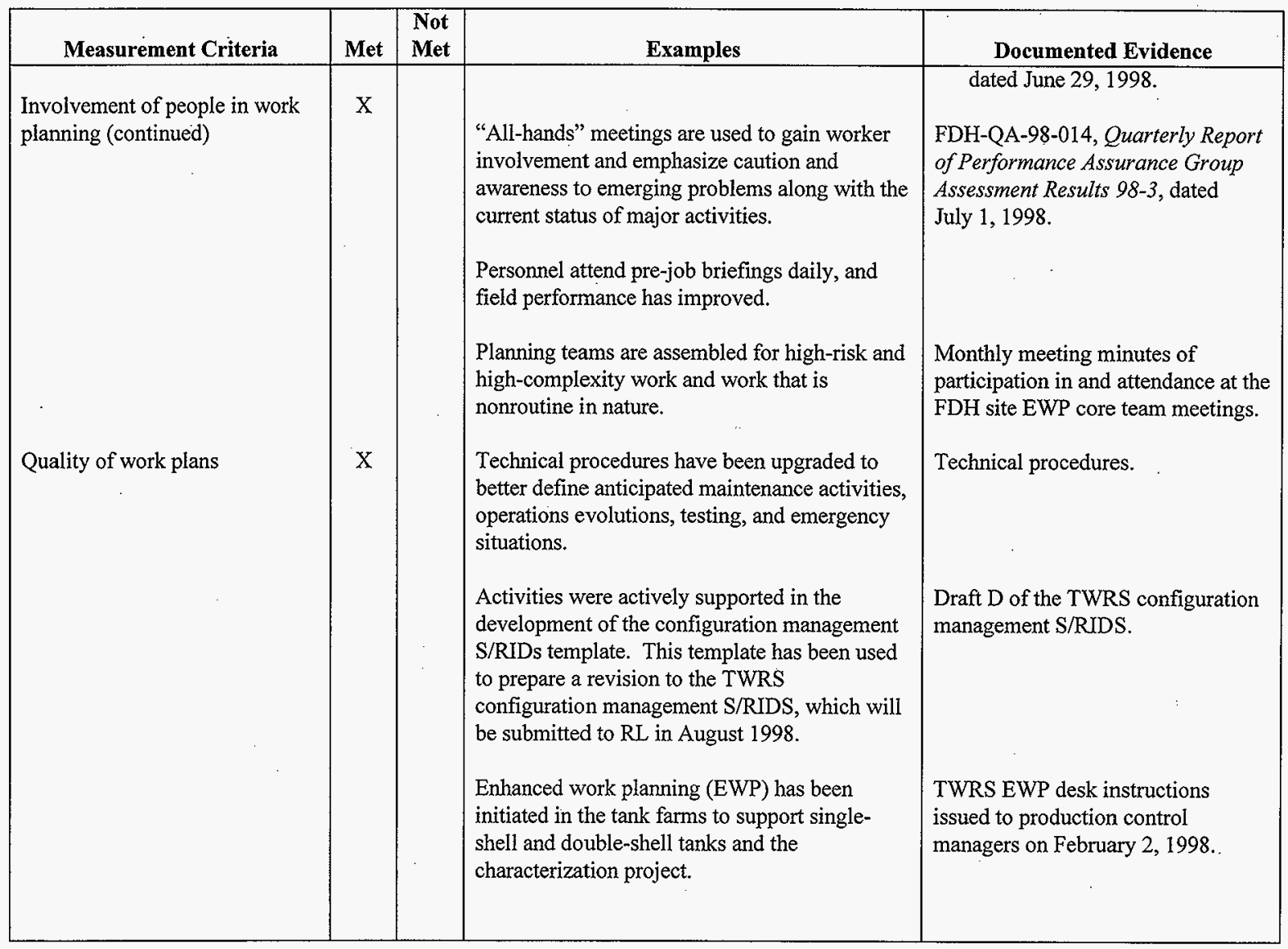




\begin{tabular}{|c|c|c|c|c|}
\hline Measurement Criteria & Met & $\begin{array}{l}\text { Not } \\
\text { Met }\end{array}$ & Examples & Documented Evidence \\
\hline \multirow[t]{4}{*}{$\begin{array}{l}\text { Continuous improvement in the } \\
\text { conduct-of-operations indices }\end{array}$} & $\mathrm{X}$ & & $\begin{array}{l}\text { Developed and successfully implemented a } \\
\text { Voluntary Protection Program initiative } \\
\text { (License to Succeed). This initiative was a } \\
\text { voluntary program that allowed employees to } \\
\text { actively participate in the TWRS safety } \\
\text { program and to become more familiar with the } \\
\text { elements of the Voluntary Protection Program. } \\
\text { A brief description of the VPP License to } \\
\text { Succeed program is shown in Figure 4.4.1-3. }\end{array}$ & $\begin{array}{l}\text { 1) License to Succeed packages } \\
\text { completed by participating } \\
\text { employees. } \\
\text { 2) The results of the initiative } \\
\text { created a workplace free of } \\
\text { injuries and illnesses using } \\
\text { employee involvement and } \\
\text { management leadership }\end{array}$ \\
\hline & & & $\begin{array}{l}\text { Record copies of compliance activities } \\
\text { completed are in Building } 2750 \mathrm{E} \text {, room C128. }\end{array}$ & $\begin{array}{l}\text { Memo, L. Jensen and S.R. Wilmarth } \\
\text { to J.S. Durham, B\&W Hanford } \\
\text { Company, Statistically Based } \\
\text { Sampling of Pipes, Tanks and Racks } \\
\text { in B-Cell, 7A120-98-026, dated } \\
\text { June 1, 1998. }\end{array}$ \\
\hline & & & $\begin{array}{l}\text { The surveillance monitoring team was } \\
\text { integrated into Process Controls and Process } \\
\text { Engineering. This change results in consistent } \\
\text { and timely analysis, interpretation, and action } \\
\text { response to waste storage condition concerns. } \\
\text { Liquid level anomalies in tanks S-110 and } \\
\text { BY-103 were resolved promptly. }\end{array}$ & $\begin{array}{l}\text { 1) Memo, D.A. Barnes to } \\
\text { C.B. Bryan, Tanks 241-S-110 } \\
\text { Liquid Level Anomaly, } \\
\text { 7A150-98-029, dated June 25, } \\
1998 . \\
\text { 2) Memo, N.W. Kirch to } \\
\text { C.B. Bryan, 24l-BY-103 } \\
\text { Interstitial Liquid Level } \\
\text { Discrepancy, 7A150-98-018, } \\
\text { dated May 8, 1998. }\end{array}$ \\
\hline & & & $\begin{array}{l}\text { As part of integrated safety management, the } \\
\text { EWP process is being refined and expanded to } \\
\text { include all work, using the graded approach. }\end{array}$ & $\begin{array}{l}\text { TWRS EWP desk instructions } \\
\text { issued to production control } \\
\text { managers on February } 2,1998 \text {. }\end{array}$ \\
\hline
\end{tabular}




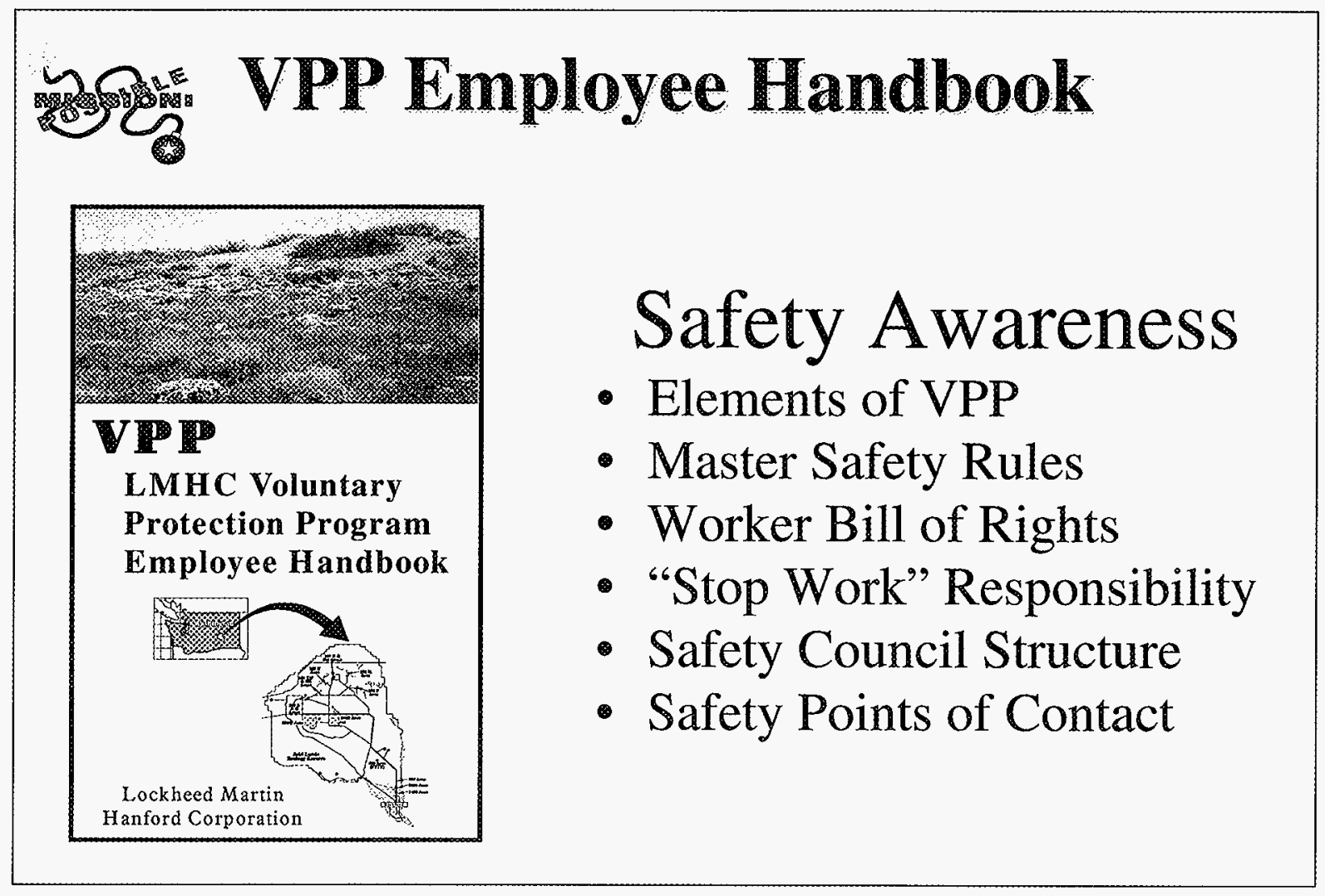


HNF-3314 REV 0

\begin{tabular}{|c|c|c|c|c|}
\hline Measurement Criteria & Met & $\begin{array}{l}\text { Not } \\
\text { Met }\end{array}$ & Examples & Documented Evidence \\
\hline $\begin{array}{l}\text { Continuous improvement in the } \\
\text { conduct-of-operations indices } \\
\text { (continued) }\end{array}$ & $\mathrm{X}$ & & $\begin{array}{l}\text { Currently, about } 50 \% \text { of all work packages } \\
\text { receive EWP. } \\
\text { Before the EWP program initiation, an EWP } \\
\text { survey was conducted (Oct 1997). Survey } \\
\text { responses from } 140 \text { personnel were reviewed to } \\
\text { establish an initial baseline of perspectives of } \\
\text { work control in the field, and to determine } \\
\text { specific areas needing focus for TWRS EWP } \\
\text { implementation. } \\
\text { Maintenance personnel actively participate in } \\
\text { the FDH Site EWP core team meetings. These } \\
\text { meetings are in the process of establishing a } \\
\text { TWRS EWP/ISM core team, and have verbally } \\
\text { briefed W.J. Schildknecht of FDH on plans for } \\
\text { full membership teams on the implementation } \\
\text { of EWP. } \\
\text { Performed an assessment for conduct of } \\
\text { maintenance follow-up. Corrective actions } \\
\text { identified and recommendations for } \\
\text { improvement have been documented. }\end{array}$ & $\begin{array}{l}\text { TWRS Maintenance Weekly Report, } \\
\text { J.C. Geisbush, LMHC, to } \\
\text { Distribution, item, Enhanced Work } \\
\text { Planning Survey, dated October } 24 \text {, } \\
\text { 1997. } \\
\text { E-mail, W.J. Schildknecht to } \\
\text { D.P. Kerwick and M.J. Powers, } \\
\text { Core Team at TWRS-EWP/LSMS, } \\
\text { dated July } 30,1998 . \\
\\
\text { Letter, W.E. Ross, LMHC, to } \\
\text { A.M. Umek, FDH, Subcontract } \\
\text { Number 80232764-9-K001; } \\
\text { Completion of Deliverable } \\
\text { 4J1 300A, Complete a Conduct of } \\
\text { Maintenance Follow-up Assessment } \\
\text { and Schedule Corrective Actions, } \\
\text { LMHC-9855534, dated } \\
\text { June } 30,1998 \text {. }\end{array}$ \\
\hline
\end{tabular}


HNF-3314 REV 0

\begin{tabular}{|c|c|c|c|c|}
\hline Measurement Criteria & Met & $\begin{array}{l}\text { Not } \\
\text { Met }\end{array}$ & Examples & Documented Evidenice \\
\hline (1) & & & $\begin{array}{l}\text { Performed radiological management } \\
\text { assessments and scheduled corrective actions } \\
\text { based on Facility Evaluation Board criteria. }\end{array}$ & $\begin{array}{l}\text { MYWP deliverable 4F30J3C, due } \\
\text { 9/30/98. Letter, TBD }\end{array}$ \\
\hline
\end{tabular}


HNF-3314 REV 0

This page intentionally left blank. 


\section{PHMC - Tank Waste Remediation System \\ Performance Expectation Plan \\ Self-Evaluation - Fiscal Year 1998}

\subsection{Performance of Work (Conduct of Operations and Maintenance, Radiological Control) Expectation}

4.4.2 Continue reporting and indexing conduct of operations events, including skin and clothing contaminations, violation of procedures, training deficiencies, management problems, lockout/tagout errors, and work control errors.

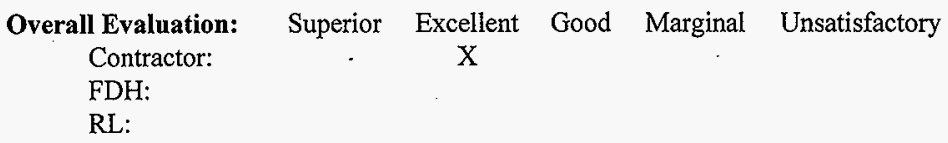

\begin{tabular}{|l|c|c|l|l|}
\hline Measurement Criteria & Met & $\begin{array}{l}\text { Not } \\
\text { Met }\end{array}$ & \multicolumn{1}{|c|}{ Examples } & \multicolumn{1}{c|}{ Documented Evidence } \\
\hline $\begin{array}{l}\text { Involvement of people in work } \\
\text { planning }\end{array}$ & $\mathrm{X}$ & & Pre-job work planning sessions conducted. . & $\begin{array}{l}\text { Daily pre-job meetings with } \\
\text { operations personnel. }\end{array}$ \\
\hline & $\begin{array}{l}\text { Teams of employees review occurrence } \\
\text { critiques. } \\
\text { An extensive effort to define, plan, and estimate } \\
\text { work requirements within TWRS was } \\
\text { undertaken. This effort will provide a basis for } \\
\text { future year work scope and funding } \\
\text { requirements for fiscal year (FY) } 99 \text { and } \\
\text { beyond. }\end{array}$ & $\begin{array}{l}\text { Technical basis review process } \\
\text { currently underway. }\end{array}$ \\
\hline
\end{tabular}


HNF-3314 REV 0

\begin{tabular}{|c|c|c|c|c|}
\hline Measurement Criteria & Met & $\begin{array}{l}\text { Not } \\
\text { Met }\end{array}$ & Examples & Documented Evidence \\
\hline $\begin{array}{l}\text { Involvement of people in work } \\
\text { planning (continued) }\end{array}$ & $\mathrm{X}$ & & $\begin{array}{l}\text { Safety documentation improvements were } \\
\text { made to resolve employee safety concerns and } \\
\text { RL safety concerns. } \\
\text { The TWRS preventive maintenance } \\
\text { optimization (PMO) team comprised of craft, } \\
\text { maintenance, engineering, and operations } \\
\text { personnel completed implementation of the } \\
\text { PMO program within single-shell and } \\
\text { double-shell tank farms. This effort built upon } \\
\text { initial efforts that eliminated more than } 7,000 \\
\text { preventive maintenance items for nonoperating } \\
\text { equipment and sent more than } 3,500 \\
\text { infrequently performed activities to an inactive } \\
\text { file. The team's efforts resulted in a further } \\
\text { reduction of } 1,859 \text { required preventive } \\
\text { maintenance work activities for a cost } \\
\text { avoidance of } \$ 555,000 \text { in FY } 98 \text { and each } \\
\text { subsequent year. } \\
\text { All of the preventive maintenance activities that } \\
\text { have been reviewed and retained as "active" } \\
\text { have a current technical basis to support their } \\
\text { performance. }\end{array}$ & 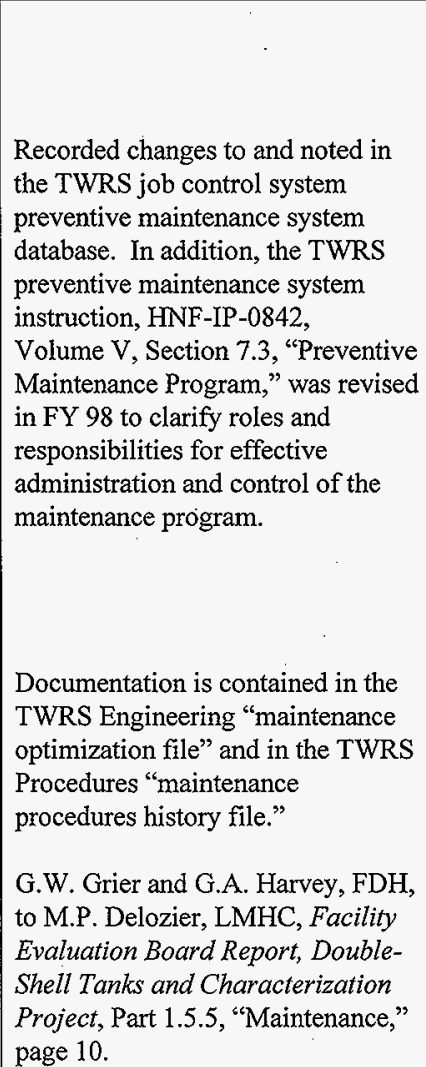 \\
\hline
\end{tabular}


HNF-3314 REV 0

\begin{tabular}{|c|c|c|c|c|}
\hline Measurement Criteria & Met & $\begin{array}{l}\text { Not } \\
\text { Met }\end{array}$ & Examples & Documented Evidence \\
\hline $\begin{array}{l}\text { Involvement of people in work } \\
\text { planning (continued) }\end{array}$ & $\mathrm{X}$ & & $\begin{array}{l}\text { to perform a similar disciplined technical } \\
\text { review of the existing preventive maintenance } \\
\text { programs. }\end{array}$ & \\
\hline \multirow[t]{3}{*}{ Quality of work plans } & $\mathrm{X}$ & & $\begin{array}{l}\text { Quality management program plan identifies } \\
\text { and describes specific areas of improvement, } \\
\text { plan action, and schedule performance. }\end{array}$ & $\begin{array}{l}\text { MYWP deliverable, } 4 J 1300 \mathrm{~B} \text {, due } \\
\text { 9/30/98. Letter, TBD }\end{array}$ \\
\hline & & & $\begin{array}{l}\text { Operating techniques for core sampling were } \\
\text { improved to permit higher than expected waste } \\
\text { sample recovery while maintaining compliance } \\
\text { with a narrow operating envelope. Some of the } \\
\text { more interesting improvements were related to } \\
\text { (1) the deployment of new samplers (finger } \\
\text { samplers) and (2) the rotary drilling of a hole } \\
\text { through hardened material followed by push } \\
\text { sampling of the waste. }\end{array}$ & $\begin{array}{l}\text { Characterization engineering } \\
\text { performance metrics-core } \\
\text { sampling availability and sample } \\
\text { recovery charts. Tracking and } \\
\text { reporting of this performance is } \\
\text { documented in monthly } \\
\text { performance indicator reports and } \\
\text { deliverables within the MYWP. }\end{array}$ \\
\hline & & & $\begin{array}{l}\text { Improvements in waste sampling equipment } \\
\text { permitted early completion of waste sample } \\
\text { collections. These improvements enhanced } \\
\text { sample system availability and waste sample } \\
\text { recovery. }\end{array}$ & $\begin{array}{l}\text { (1) Acceptance for beneficial use for } \\
\text { liquid nitrogen vaporizer. } \\
\text { (2) Engineering change notice } \\
\text { (ECN) for improved calibration } \\
\text { tool for load hoist cells. } \\
\text { (3) ECN for the electrical } \\
\text { compatibility improvements. }\end{array}$ \\
\hline $\begin{array}{l}\text { Continuous improvement in the } \\
\text { conduct-of-operations indices }\end{array}$ & $\mathrm{X}$ & & $\begin{array}{l}\text { Good work practices in the areas of procedures, } \\
\text { training, work control, and lockout/tagout } \\
\text { continue. Emphasis on work practices in the } \\
\text { areas of skin and clothing contamination } \\
\text { continues. }\end{array}$ & $\begin{array}{l}\text { TMX is monitored to ensure } \\
\text { personnel are trained and aware of } \\
\text { procedure changes. } \\
\text { A health and safety self-assessment } \\
\text { was conducted on lockout/tagout for }\end{array}$ \\
\hline
\end{tabular}


HNF-3314 REV 0

\begin{tabular}{|c|c|c|c|c|}
\hline Measurement Criteria & Met & $\begin{array}{l}\text { Not } \\
\text { Met }\end{array}$ & Examples & Documented Evidence \\
\hline $\begin{array}{l}\text { Continuous improvement in the } \\
\text { conduct-of-operations indices } \\
\text { (continued) }\end{array}$ & $X$ & & $\begin{array}{l}\text { Personnel contamination trends continue to } \\
\text { improve because of proactive leadership and } \\
\text { involvement of workers in addressing problems } \\
\text { and developing solutions. } \\
\text { Very low rate of events attributed to procedure } \\
\text { index violations continues. Figure } 4.4 .2-1 \\
\text { shows the monthly frequency of violation of } \\
\text { procedure. }\end{array}$ & $\begin{array}{l}\text { Characterization on July 9, } 1998 \text {. } \\
\text { Memo, C.N. Hogan, to D.I. Allen, } \\
\text { Transmittal of the } 1998 \text { Periodic } \\
\text { Inspection of Lockheed Martin } \\
\text { Hanford Corporation's Hazardous } \\
\text { Energy Control Program, } \\
7 \text { B400-98-008. } \\
\text { A performance indicator chart is } \\
\text { trended monthly for skin/clothing } \\
\text { contaminations (monthly } \\
\text { performance indicator package). } \\
\text { Performance indicator on skin and } \\
\text { clothing contaminations, } \\
\text { Correspondence No. } 71500-98-032 \text {, } \\
\text { Performance Indicators, dated } \\
\text { July } 29,1998 \text {. } \\
\text { Conduct-of-operations index, } \\
\text { Correspondence No.71500-98-032, } \\
\text { Performance Indicators, dated } \\
\text { July } 29,1998 \text {. }\end{array}$ \\
\hline & & & $\begin{array}{l}\text { Zero lockout/tagout errors this year. } \\
\text { Conduct-of-operations status is reported } \\
\text { monthly. Occurrence reports are monitored and }\end{array}$ & $\begin{array}{l}\text { LO/TO surveillance records and } \\
\text { FEB-FY98-004-DST/CP, } \\
\text { April } 9,1998 \text {. } \\
\text { Monthly performance indicator } \\
\text { charts are provided to management }\end{array}$ \\
\hline
\end{tabular}




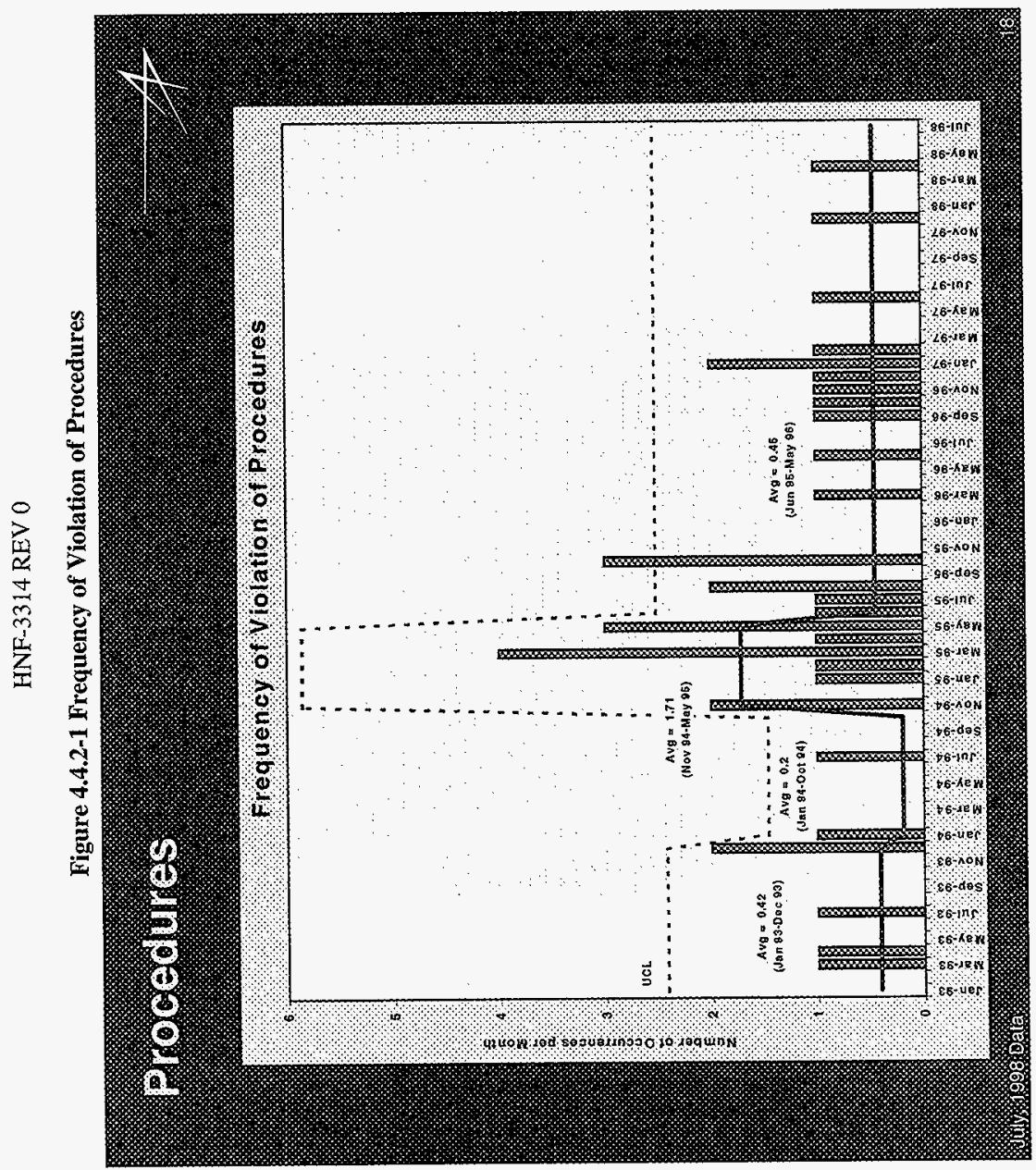




\begin{tabular}{|l|l|l|l|l|}
\hline \multicolumn{1}{|c|}{ Measurement Criteria } & Met & $\begin{array}{l}\text { Not } \\
\text { Met }\end{array}$ & \multicolumn{1}{|c|}{ Examples } & \multicolumn{1}{c|}{ Documented Evidence } \\
\hline $\begin{array}{l}\text { Continuous improvement in the } \\
\text { conduct-of-operations indices } \\
\text { (continued) }\end{array}$ & $\mathrm{X}$ & & $\begin{array}{l}\text { follow-up reporting for corrective actions is } \\
\text { provided. The monthly CONOPS Event Index } \\
\text { is shown in Figure 4.4.2-2. }\end{array}$ & $\begin{array}{l}\text { and posted on display boards. } \\
\text { Events are discussed at pre-job } \\
\text { meetings, and plans from weekly } \\
\text { meetings are discussed. } \\
\text { FDH-QA-98-014, Quarterly Report } \\
\text { of Performance Assurance Group } \\
\text { Assessments Results 98-3, dated } \\
\text { July 1, 1998. }\end{array}$ \\
$\begin{array}{l}\text { Preventive maintenance optimization program } \\
\text { implemented. This graded approach to } \\
\text { optimization increases equipment reliability } \\
\text { and availability while reducing maintenance } \\
\text { costs. } \\
\text { An effective path forward was established and a a } \\
\text { work plan developed and initiated for single- } \\
\text { shell interim stabilization (saltwell pumping). }\end{array}$ & $\begin{array}{l}\text { Rev. 1, dated May 11, 1998. } \\
\text { interim Stabilization Project Plan, } \\
\text { Technical support in response to the } \\
\text { intent to sue for saltwell pumping. }\end{array}$ \\
\hline
\end{tabular}


Figure 4.4.2-2 Monthly CONOPS Event Index

\section{Conduct of Operations}

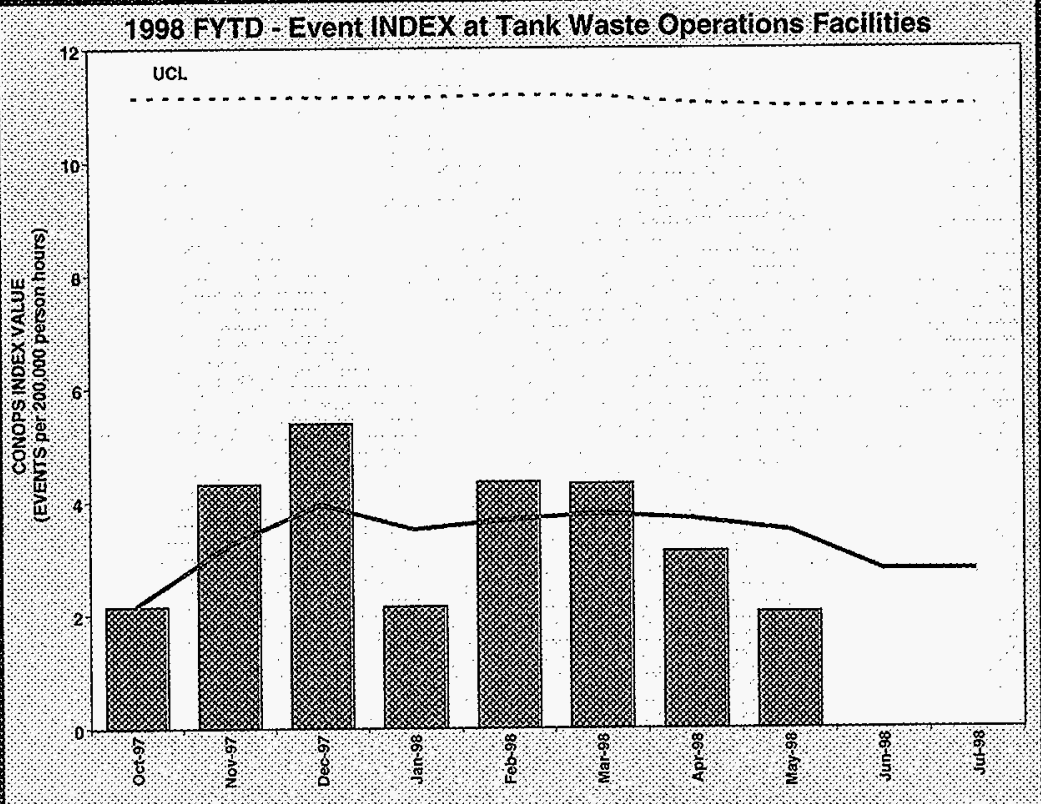

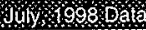




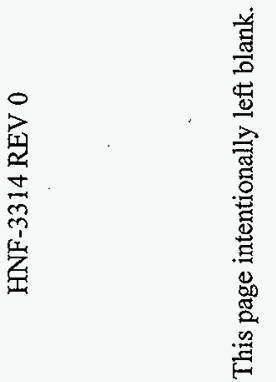




\section{PHMC - Tank Waste Remediation System \\ Performance Expectation Plan \\ Self-Evaluation - Fiscal Year 1998}

4.5 Schedule Performance Expectation: Meet all MYWP milestones and schedules not included in the performance agreements.

Develop realistic schedules appropriate for the work activities conducted. Accelerate scheduled activities that will result in meeting key objectives earlier or will reduce mortgage costs (stretch).

\section{Overall Evaluation: Superior Excellent Good Marginal Unsatisfactory \\ Contractor: \\ $\mathrm{X}$}

FDH:

RL:

\begin{tabular}{|l|c|c|l|l|}
\hline \multicolumn{1}{|c|}{ Measurement Criteria } & Met & $\begin{array}{l}\text { Not } \\
\text { Met }\end{array}$ & \multicolumn{1}{|c|}{ Examples } & \multicolumn{1}{c|}{ Documented Evidence } \\
\hline $\begin{array}{l}\text { Dates milestones and schedules } \\
\text { met as compared to MYWP }\end{array}$ & $\mathrm{X}$ & $\begin{array}{l}\text { TWRS has 33 controlled milestones for FY } \\
1998, \text { excluding performance agreements. } \\
\text { Through July, 19 were planned with 16 } \\
\text { complete including 14 completed ahead of } \\
\text { schedule. The 3 incomplete milestones are } \\
\text { associated with pending TPA change requests } \\
\text { for stabilization, tank C-106 sluicing, and } \\
\text { privatization go ahead. Work is on schedule } \\
\text { per pending proposed plans. At year's end, 30 } \\
\text { of 33 milestones are forecasted to be complete } \\
\text { (91\%). The additional 2 forecasted missed } \\
\text { milestones are tied to (1) interim stabilization } \\
\text { TPA renegotiations and (2) RL-approved }\end{array}$ & $\begin{array}{l}\text { See attached summary status. } \\
\text { Performance documented in site } \\
\text { monthly reports and audited by } \\
\text { DOE at fiscal year end. }\end{array}$ \\
\hline
\end{tabular}


HNF-3314 REV 0

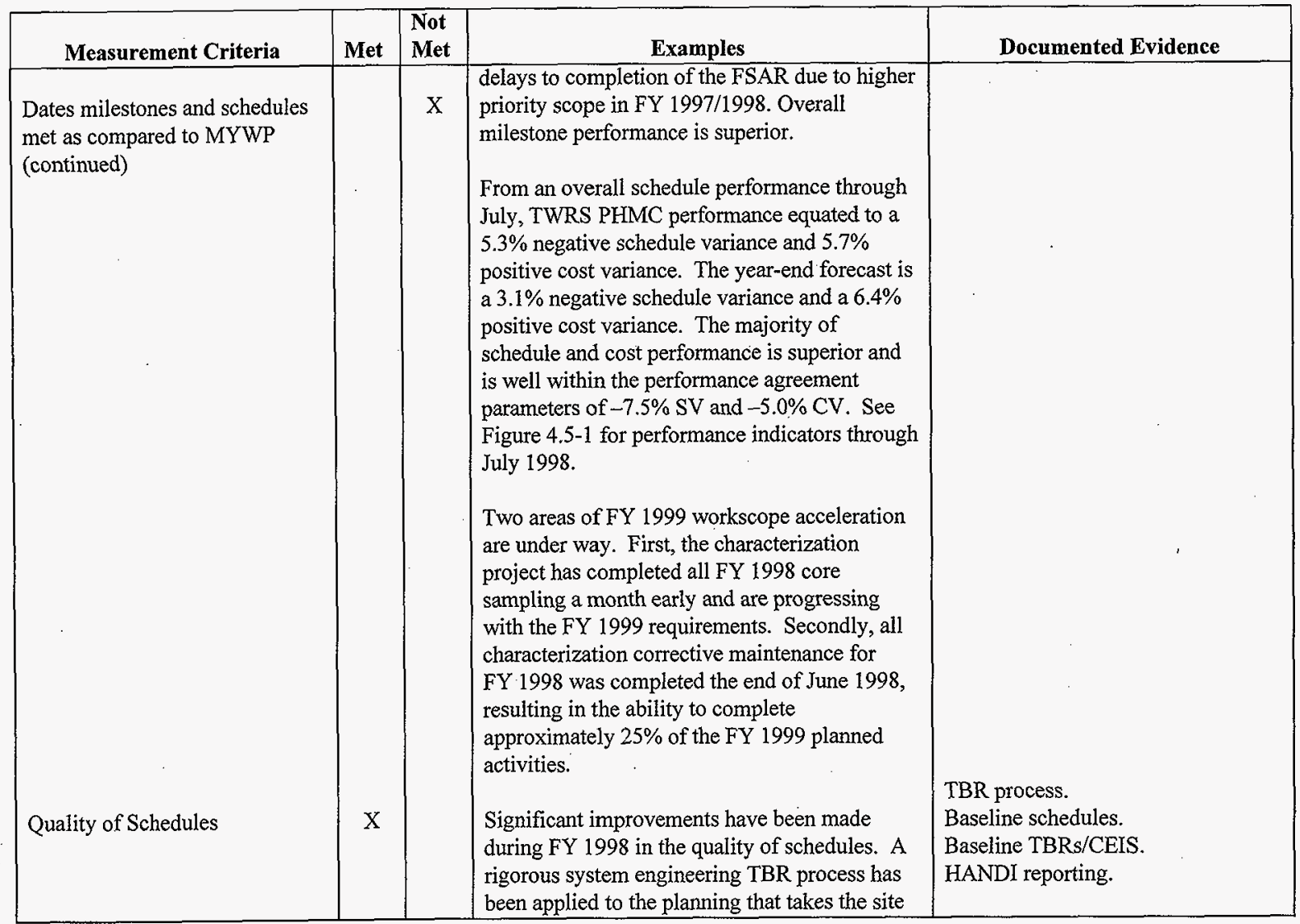




\section{HNF-3314 REV 0}

Figure 4.5-1

\begin{tabular}{|c|c|c|}
\hline Project Review & $\begin{array}{c}\text { Lockheed Martin Hanford Corporation } \\
\text { Tank Waste Remediation System }\end{array}$ & $\ldots$ \\
\hline
\end{tabular}

\section{COST/SCHEDULE PERFORMANCE - ALL FUND TYPES}

PHMC ONLY

(Dollars in Millions)

\begin{tabular}{|c|c|c|c|c|c|c|c|c|c|c|c|c|c|}
\hline & \multirow{4}{*}{ RBS / TITLE } & \multirow{2}{*}{\multicolumn{7}{|c|}{ FISCAL YEAR TO DATE }} & \multicolumn{5}{|c|}{ ANNUAL DATA } \\
\hline & & \multirow{2}{*}{\multicolumn{2}{|c|}{$\begin{array}{c}\text { BUDGET } \\
\text { COST }\end{array}$}} & \multirow{3}{*}{$\begin{array}{l}\text { ACTUAL } \\
\text { COST } \\
\text { WORK } \\
\text { PERF }\end{array}$} & \multirow{2}{*}{\multicolumn{4}{|c|}{ VARIANCE }} & \multirow[b]{3}{*}{$B A C$} & \multirow{3}{*}{$\begin{array}{r}\text { EXPTD } \\
\text { FUNDS } \\
\text { FY98 } * 1,1 \\
\end{array}$} & \multirow{3}{*}{$\begin{array}{l}\text { JULY } \\
\text { FYSF1 }\end{array}$} & \multirow{2}{*}{\multicolumn{2}{|c|}{ FORECAST }} \\
\hline & & & & & & & & & & & & & \\
\hline & & $\begin{array}{l}\text { WORK } \\
\text { SCHED }\end{array}$ & $\begin{array}{l}\text { WORK } \\
\text { PERF }\end{array}$ & & SCHED & $\begin{array}{c}\text { SCHEO } \\
\%\end{array}$ & $\cos T$ & $\begin{array}{c}\cos r \\
\%\end{array}$ & & & & \begin{tabular}{l|} 
YE \\
SV
\end{tabular} & $\begin{array}{l}\text { YE } \\
C V\end{array}$ \\
\hline \multicolumn{2}{|c|}{ ALL FUND TYPES } & & & & & & & & & & & & \\
\hline TW10 & MANAGEMENT SYSTEMS & 30.4 & 29.3 & 27.5 & $(1,1)$ & $(3.6) \%$ & 1.8 & $6.1 \%$ & 37.5 & 35.8 & 36.0 & $(0.8)$ & 0.5 \\
\hline \multirow[t]{5}{*}{ IW03 } & OPER'NS \& MAINT-EXCE & 73.3 & 70.5 & 75.8 & (2.8) & $(3.8) \%$ & (5.3) & $(7.5) \%$ & 89.7 & 96.1 & 96.2 & (4.2) & 4.1 \\
\hline & W314-LI & 14.1 & 8.6 & 7.5 & (5.5) & $(39.0) \%$ & 1.1 & $12.8 \%$ & 22.1 & 17.7 & 10.2 & $(2,2)$ & 3.1 \\
\hline & W.030.LI & 3.0 & 3.4 & 3.1 & 0.4 & $13.3 \%$ & 0.3 & $8.8 \%$ & 3.0 & 3,4 & 3.2 & 0.4 & 0.2 \\
\hline & W.058 +LI & $\underline{2.3}$ & $\underline{2,3}$ & 2.5 & $\underline{0.0}$ & $\underline{0.0} \%$ & $(0.2)$ & $(8.7) \%$ & 2.3 & 3.4 & $\underline{3.4}$ & $\underline{0.0}$ & $(1.1)$ \\
\hline & TOTAL OPS & 92.7 & 84.8 & 88.9 & (7.9) & $(8.5) \%$ & (4.1) & $(4.8) \%$ & $\uparrow 17.1$ & 120.6 & 113.0 & (6.0) & 6.3 \\
\hline TWO2 & SAFETY & 22.5 & 22.0 & 19.5 & $(0.5)$ & $(2.2) \%$ & 2.5 & $\$ 1.4 \%$ & 25.9 & 24.5 & 23.9 & $(0.7)$ & 1.2 \\
\hline TW01 & CHARACTERIZATION & 39.5 & 39.5 & 32.8 & 0.0 & $0.0 \%$ & 6.7 & $17.0 \%$ & 47.4 & 42.1 & 41.1 & 0.0 & 6.5 \\
\hline \multirow[t]{4}{*}{ TWO4 } & RETRIEVAL PROJ. EXICE & 35.5 & 32.2 & 34.7 & (3.3) & $(9.3) \%$ & (2.5) & $(7.8) \%$ & 43.2 & 43.5 & 43.4 & $(1.6)$ & (2.1) \\
\hline & W-151-LI & 0.0 & 0.0 & (0.3) & 0.0 & $0.0 \%$ & 0.3 & $0.0 \%$ & 0.0 & 0.0 & (0.2) & 0.0 & 0.2 \\
\hline & W-211 - LI & 10.9 & 11.3 & $\underline{5.8}$ & $\underline{0.4}$ & $\underline{3.7} \%$ & 5.5 & $48.7 \%$ & 15.2 & 15.1 & 8.9 & $\underline{0.0}$ & 6.2 \\
\hline & TOTAL RETRIEVAL & 46.4 & 43.5 & 40.2 & (2.9) & $(6.2) \%$ & 3.3 & $7.6 \%$ & 58.4 & 58.6 & 52.1 & $(1.6)$ & 4.3 \\
\hline TW05 & PROCESS WASTE SUPPORT & 0.6 & 0.5 & 0.2 & (0.1) & $(16.7) \%$ & 0.3 & $60.0 \%$ & 0.9 & 0.6 & 0.6 & $(0.1)$ & 0.1 \\
\hline TW08 & PRIVAT'ZN INFRASTRUCTURE & 4.8 & 4.9 & 3.4 & 0.1 & $2.1 \%$ & 1.5 & $30.6 \%$ & 6.1 & 5.4 & 5.4 & $(0.2)$ & 0.6 \\
\hline \multirow[t]{4}{*}{ IWOS } & STORAGE \& DISPOSAL & 8.8 & 8.5 & 7.4 & (0.3) & (3.4) $\%$ & 1.1 & $12.9 \%$ & 10.9 & 10.2 & 10.1 & $(0.1)$ & 0.2 \\
\hline & HANFORD TANK INITIATIVE & 4.2 & 3.7 & 3.2 & $(0.5)$ & $(11.9) \%$ & 0.5 & $13.5 \%$ & $6.4 *$ & 6.5 & 6.3 & $(0.3)$ & $(0.1)$ \\
\hline & PROGRAM RESERVE & $\underline{0.0}$ & 0.0 & 0.0 & $\underline{0.0}$ & $\underline{0.0} \%$ & $\underline{0.0}$ & $\underline{0.0} \%$ & $\underline{0.0}$ & $\underline{0.2}$ & $\underline{0.0}$ & $\underline{0.0}$ & $\underline{0.0}$ \\
\hline & TOTAL TWRS & 2499 & 2367 & 223.1 & (13.2) & $(5.3) \%$ & 13.6 & $57 \%$ & 310.6 & 304.5 & 288.5 & (9.8) & 19.6 \\
\hline
\end{tabular}

** Expected funds are defined as the total funding guidance expected at fiscal year end (includes anticipated approval of change requests, carryover, reprogramming actions, and reserve hold backs)

1 Expected Funds and FYSF include all pending $8 \mathrm{CRs}$. 


\begin{tabular}{|c|c|c|l|l|}
\hline Measurement Criteria & Met & $\begin{array}{l}\text { Not } \\
\text { Met }\end{array}$ & \multicolumn{1}{|c|}{ Supporting Facts } & Documented Evidence \\
\hline Quality of schedules (continued) & $\mathrm{X}$ & & $\begin{array}{l}\text { mission end-states and technical requirements } \\
\text { and decomposes them into logical work flows } \\
\text { that are resource loaded and cost estimated. } \\
\text { The TBR Package Preparation Process flow } \\
\text { chart is illustrated in Figure 4.5-2. Schedules } \\
\text { are tied to technical work, contain solid cost } \\
\text { estimates, have no open ends, and are tied to } \\
\text { the Hanford Site technical database (HSTD). } \\
\text { Risk analysis has also been performed on the } \\
\text { retrieval and saltwell pumping baselines to } \\
\text { substantiate executability. Finally, TWRS has } \\
\text { initiated the use of these schedules as the } \\
\text { official reporting mechanism which provides } \\
\text { high quality and confidence in accuracy and } \\
\text { integrity. Overall scheduling is excellent. }\end{array}$ & \\
\hline
\end{tabular}




\section{TBR Package Preparation}
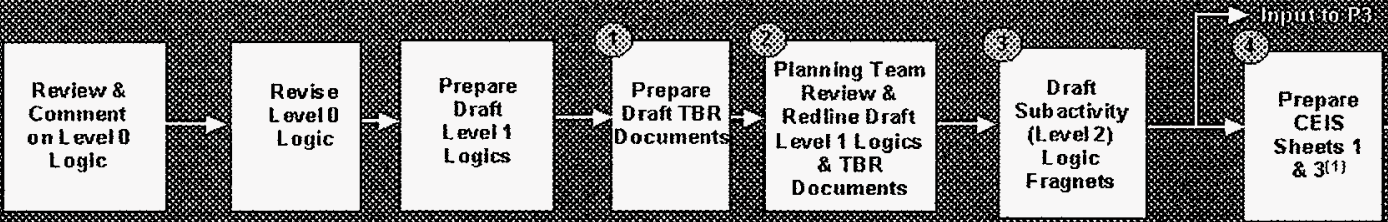

$\sin \sin$

Dositiono

obitic

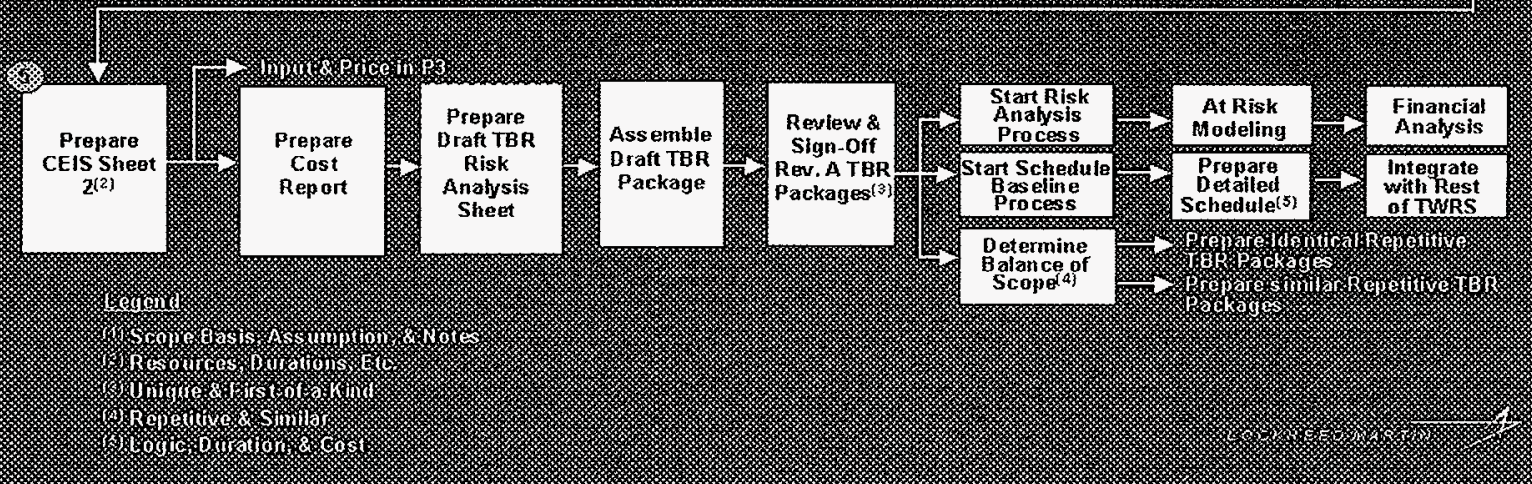




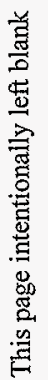




\section{PHMC - Tank Waste Remediation System Performance Expectation Plan Self-Evaluation - Fiscal Year 1998}

4.6 Cost Performance Expectation: Complete work scope within budget as defined in the MYWP. Develop realistic cost estimates for work activities (neither too high nor too low and with adequate detail).

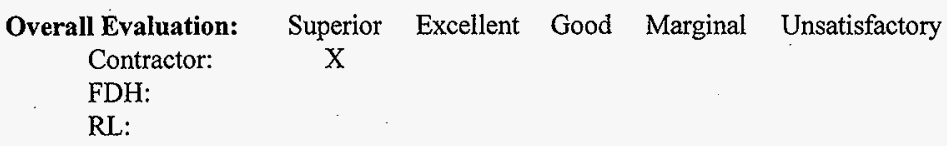

\begin{tabular}{|l|c|c|l|l|}
\hline \multicolumn{1}{|c|}{ Measurement Criteria } & Met & $\begin{array}{l}\text { Not } \\
\text { Met }\end{array}$ & \multicolumn{1}{|c|}{ Examples } & Documented Evidence \\
\hline $\begin{array}{l}\text { Cost of completing work scope } \\
\text { as compared to the MYWP } \\
\text { estimated cost }\end{array}$ & $\mathrm{X}$ & & $\begin{array}{l}\text { Overall - TWRS is forecasting to complete } \\
\$ 308.1 \mathrm{M} \text { of equivalent MYWP estimated scope } \\
\text { for } \$ 288.4 \mathrm{M} \text {. Of the underrun, } \$ 8.5 \mathrm{M} \text { is } \\
\text { attributable to aggressive indirect rate savings. } \\
\text { If you add the } \$ 8.5 \mathrm{M} \text { to the } \$ 288.4 \mathrm{M} \text { you get a } \\
\text { "normalized estimated" cost of } \$ 296.9 \mathrm{M} \text { or } \\
\text { within } ~ \\
\text { baseline was also reviewed by a third party to } \\
\text { validate basis of estimating at the beginning of } \\
\text { the fiscal year with no significant findings. } \\
\text { TWRS has prepared a detailed executability } \\
\text { probabilistic risk analysis for RTP and SWP, } \\
\text { providing quantified requirements for an } 80 \% \\
\text { executable plan. Overall estimates are superior. }\end{array}$ & $\begin{array}{l}\text { Audited year-end cost and schedule } \\
\text { variance analysis. See July forecast, } \\
\text { attached. }\end{array}$ \\
\hline
\end{tabular}


HNF-3314 REV 0

\begin{tabular}{|c|c|c|c|c|}
\hline Measurement Criteria & Met & $\begin{array}{l}\text { Not } \\
\text { Met }\end{array}$ & Examples & Documented Evidence \\
\hline Quality of new cost estimates. & $\mathrm{X}$ & & $\begin{array}{l}\text { The quality of new cost estimates is superior. } \\
\text { Professional cost estimators prepared detail cost } \\
\text { estimates by cost element by activity, utilizing } \\
\text { interviews, historical records, engineering } \\
\text { judgement, parametrics, etc. Third-party } \\
\text { reviews have been conducted with positive } \\
\text { results. } \\
\text { TWRS has continued to find cost efficiencies } \\
\text { (e.g., characterization) and process } \\
\text { improvements, resulting in effective funds } \\
\text { management initiatives to maximize cleanup } \\
\text { progress while funding critical initiatives such } \\
\text { as BNFL contract extension. }\end{array}$ & $\begin{array}{l}\text { TBR process and FY } 1999 \\
\text { estimates. } \\
\text { PT\&C reviews. } \\
\text { Corp of Engineering reviews. } \\
\text { FDH reviews (e.g., BOE). }\end{array}$ \\
\hline
\end{tabular}




\section{PHMC - Tank Waste Remediation System Performance Expectation Plan Self-Evaluation - Fiscal Year 1998}

4.7 Rework Required Expectation: Perform work such that there is little or no rework required that is a result of things that are within the Contractor's control.

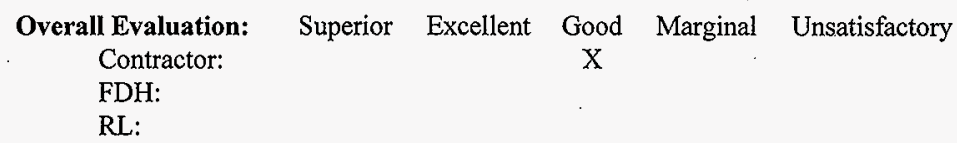

\begin{tabular}{|c|c|c|c|c|}
\hline Measurement Criteria & Met & $\begin{array}{l}\text { Not } \\
\text { Met }\end{array}$ & Examples & Documented Evidence \\
\hline $\begin{array}{l}\text { Amount and seriousness of } \\
\text { rework required }\end{array}$ & $\mathrm{X}$ & & $\begin{array}{l}\text { Between October } 1,1997 \text { and August } 3,1998 \text {, } \\
3,160 \text { maintenance work activities were } \\
\text { performed with only } 2 \text { requiring rework ( } 1 \text { out } \\
\text { of every } 1,580 \text { work packages). Because the } \\
\text { rework items were discovered during } \\
\text { post-maintenance testing, the equipment was } \\
\text { not operating in direct facility support and } \\
\text { facility impacts were minimal. (The FY } 97 \\
\text { rework rate was } 1 \text { out of every } 621 \text { work } \\
\text { packages.) } \\
\text { The DST system specification did not meet RL } \\
\text { expectations and needed rework, thereby } \\
\text { missing the original schedule. }\end{array}$ & $\begin{array}{l}\text { Rework is tracked as post-work test } \\
\text { failure and is one of the elements } \\
\text { measured in the work package } \\
\text { suspensions performance indicator } \\
\text { developed and used by TWRS } \\
\text { maintenance. } \\
\text { Letter, H.L. Boston, LMHC, to } \\
\text { A.M. Umek, FDH, Subcontract } \\
\text { Number 80232764-9-K001; Defense } \\
\text { Nuclear Facility Safety Board }\end{array}$ \\
\hline
\end{tabular}


HNF-3314 REV 0

\begin{tabular}{|l|c|c|c|l|}
\hline \multicolumn{1}{|c|}{ Measurement Criteria } & Met & $\begin{array}{l}\text { Not } \\
\text { Met }\end{array}$ & Examples & \multicolumn{1}{|c|}{ Documented Evidence } \\
\hline $\begin{array}{l}\text { Amount and seriousness of } \\
\text { rework required (continued) }\end{array}$ & $\mathrm{X}$ & & & $\begin{array}{l}\text { Recommendation } 92-4, \\
\text { Commitments } 5.2 .1 . a \text { and 5.2.1.b, } \\
\text { Technical Basis for Project } W-211, \\
\text { LMHC-9850-461 R2, dated } \\
\text { February 2, 1998. }\end{array}$ \\
\hline
\end{tabular}




\section{PHMC - Tank Waste Remediation System Performance Expectation Plan \\ Self-Evaluation - Fiscal Year 1998}

4.8 Energy Efficiency and Pollution Prevention Performance Expectation: Identify and implement energy efficiency improvements (independent of the Johnson Controls contract effort). Identify and implement pollution prevention improvements.

Overall Evaluation: Superior Excellent Good Marginal Unsatisfactory

Contractor:

FDH:

RL:

\begin{tabular}{|l|l|l|l|l|}
\hline \multicolumn{1}{|c|}{ Measurement Criteria } & Met & $\begin{array}{l}\text { Not } \\
\text { Met }\end{array}$ & \multicolumn{1}{|c|}{ Examples } & Documented Evidence \\
\hline $\begin{array}{l}\text { Number of energy efficiency } \\
\text { improvements implemented }\end{array}$ & N/A & & N/A for TWRS Project. & \\
$\begin{array}{l}\text { Number of pollution prevention } \\
\text { improvements funded from the } \\
\text { pollution prevention account. }\end{array}$ & N/A & N/A for TWRS Project. & \\
\hline
\end{tabular}




\section{HNF-3314 REV 0}

This page intentionally left blank. 


\section{PHMC - Tank Waste Remediation System Performance Expectation Plan \\ Self-Evaluation - Fiscal Year 1998}

4.9 Project Management Performance Expectation: Project managers understand, plan, manage and control their projects; provide timely, focused, project status reports and briefings; and support the DOE project managers in a cooperative manner.

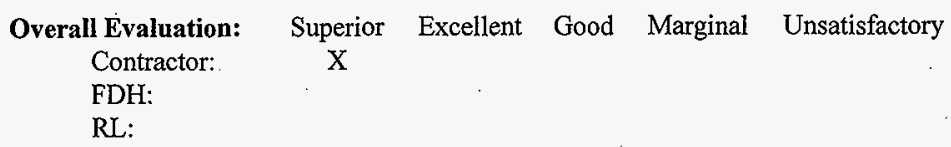

\begin{tabular}{|l|l|l|l|l|}
\hline Measurement Criteria & Met & $\begin{array}{l}\text { Not } \\
\text { Met }\end{array}$ & \multicolumn{1}{|c|}{ Examples } & \multicolumn{1}{|c|}{ Documented Evidence } \\
\hline $\begin{array}{l}\text { Project manager performance in } \\
\text { conducting projects - Planning }\end{array}$ & $\mathrm{X}$ & & $\begin{array}{l}\text { RL looks to the prime Contractor to provide } \\
\text { strategic approaches to planning, solve funding } \\
\text { problems, control performance baselines, drive } \\
\text { business processes, and migrate to new } \\
\text { business systems. }\end{array}$ & $\begin{array}{l}\text { Management Support Systems (MSP) manages } \\
\text { and controls the project through quality budget } \\
\text { planning, IPL development and integration, } \\
\text { detailed status analysis, monthly briefings, } \\
\text { funds control, instilling sound system } \\
\text { engineering principles, and supporting all } \\
\text { requests. As an example, MSP drives the } \\
\text { integration of the HSTD into the FY 1999 }\end{array}$ \\
\hline
\end{tabular}


HNF-3314 REV 0

\begin{tabular}{|c|c|c|c|c|}
\hline Measurement Criteria & Met & $\begin{array}{l}\text { Not } \\
\text { Met }\end{array}$ & Examples & Documented Evidence \\
\hline $\begin{array}{l}\text { Project manager performance in } \\
\text { conducting projects - Planning } \\
\text { (continued) }\end{array}$ & $X$ & $\cdot$ & $\begin{array}{l}\text { WBS, providing traceability between technical } \\
\text { and programmatic baselines. } \\
\text { Use of the technical baseline review (TBR) } \\
\text { packages, developed under the Phase 1B } \\
\text { privatization readiness-to-proceed activity, have } \\
\text { been applied across TWRS to more effectively } \\
\text { describe the scope, schedule, and resources } \\
\text { required for performance of TWRS tasks. } \\
\text { Provided re-validation of Project W-519 } \\
\text { information to RL. }\end{array}$ & $\begin{array}{l}\text { HNF-2017, Tank Waste } \\
\text { Remediation System Retrieval and } \\
\text { Disposal Mission Phase I Financial } \\
\text { Analysis, Rev. 1," dated } \\
\text { January 1998. } \\
\text { Letter, P.R. Angelier, LMHC/NHC, } \\
\text { to A.M. Umek, FDH, "Subcontract } \\
\text { Number 80232764-9-K001; } \\
\text { Validation Books for Tank Waste } \\
\text { Remediation System Construction } \\
\text { Projects Requesting Fiscal Year } \\
\text { 2000 Funding, LMHC-9852317, } \\
\text { dated March 17, 1998. }\end{array}$ \\
\hline $\begin{array}{l}\text { Project manager performance in } \\
\text { conducting projects - } \\
\text { Management and Control }\end{array}$ & $\mathrm{X}$ & & $\begin{array}{l}\text { Effectively utilized funding efficiencies within } \\
\text { the TWRS program to initiate emerging high- } \\
\text { priority work. An excellent example is the tank } \\
\text { 101-SY path forward. } \\
\text { Significant cost efficiencies were obtained by } \\
\text { completing actions that allowed standard } \\
\text { hydrogen monitoring systems to be installed } \\
\text { and accepted for beneficial use. These units } \\
\text { will allow tank farms to greatly increase the } \\
\text { database of flammable gas information } \\
\text { available to support resolution of the flammable } \\
\text { gas safety issue. }\end{array}$ & $\begin{array}{l}\text { Baseline change request log } \\
\text { Letter, A.M. Umek, FDH, to C.L. } \\
\text { Sohn, RL, Contract Number } \\
\text { DE-AC06-96RL13200, Notification } \\
\text { of Completion of Increased } \\
\text { Performance Level of PA TWR } \\
\text { 1.1.4, FDH-9854655, dated May 28, } \\
\text { 1998. }\end{array}$ \\
\hline
\end{tabular}




\section{HNF-3314 REV 0}

\begin{tabular}{|c|c|c|c|c|}
\hline Measurement Criteria & Met & $\begin{array}{l}\text { Not } \\
\text { Met }\end{array}$ & Examples & Documented Evidence \\
\hline $\begin{array}{l}\text { Project manager performance in } \\
\text { conducting projects - } \\
\text { Management and Control } \\
\text { (continued) }\end{array}$ & $X$ & & $\begin{array}{l}\text { TWRS provided the leadership for the } \\
\text { development and implementation of the PHMC } \\
\text { engineering metrics. These metrics provide } \\
\text { monthly information on the number of } \\
\text { engineering drawing categories and engineering } \\
\text { change notices for all major subcontractors. } \\
\text { Improvements were made to the temporary } \\
\text { ECN (engineering change notice) status. This } \\
\text { has resulted in a significant reduction of } \\
\text { temporary ECNs. } \\
\text { Work was initiated to incorporate ECNs into } \\
\text { essential drawings. In addition, a goal was } \\
\text { established to have all drawings with } \\
\text { outstanding ECNs updated by } 10 / 1 / 98 \text {. }\end{array}$ & $\begin{array}{l}\text { Letter, FDH to RL, Re: PEP } 14.1 \\
\text { (1) Weekly reports from Single- } \\
\text { Shell Tanks (SST) Engineering, } \\
\text { Double-Shell Tanks (DST) } \\
\text { Engineering, and } \\
\text { Characterization Engineering } \\
\text { show a reduction of overdue } \\
\text { temporary ECNs from } 52 \text { to less } \\
\text { than } 10 \text {. } \\
\text { (2) E-mail, from W.E. Bryan dated } \\
\text { 8/3/98. } \\
\text { Results of these efforts will be } \\
\text { apparent in the FDH engineering } \\
\text { drawing metrics in the } \\
\text { August/September/October reports. } \\
\text { Tri-Party Agreement change request } \\
\text { M-44-97-03 to revise the strategy } \\
\text { and refine the tank waste } \\
\text { characterization process of } \\
\text { collecting tank data/information was } \\
\text { approved by Ecology on } \\
\text { December } 10,1997 \text { and EPA on } \\
\text { December } 18,1997 \text {. } \\
\text { (1) }\end{array}$ \\
\hline
\end{tabular}


HNF-3314 REV 0

\begin{tabular}{|c|c|c|c|c|}
\hline Measurement Criteria & Met & $\begin{array}{l}\text { Not } \\
\text { Met }\end{array}$ & Examples & Documented Evidence \\
\hline $\begin{array}{l}\text { Project manager performance in } \\
\text { conducting projects - } \\
\text { Management and Control } \\
\text { (continued) }\end{array}$ & $\mathrm{X}$ & & $\begin{array}{l}\text { Established a formal method to complete } \\
\text { design reviews of all modifications to safety } \\
\text { related (SC and SS) equipment. This is a } \\
\text { significant improvement over past performance. } \\
\text { Improvements to the Plant Review Committee } \\
\text { (PRC) were made to optimize the technical } \\
\text { review process on critical TWRS issues and/or } \\
\text { concerns. These improvements allowed work } \\
\text { to continue with close management } \\
\text { involvement. }\end{array}$ & $\begin{array}{l}\text { (1) 647656/B.K. Everett, Pit } \\
\text { Supplemental Covers, dated } \\
\text { 4/14/98. } \\
\text { (2) ECN-645480/B.K. Everett, Pit } \\
\text { Supplemental Covers dated } \\
\text { 3/2/98. } \\
\text { (3) ECN-647657/B.K. Everett, Pit } \\
\text { Supplemental Covers, dated } \\
\text { 4/22/98. } \\
\text { (4) ECN-645479/B.K. Everett, COB } \\
\text { Enclosure/NF2C1, dated 3/2/98. } \\
\text { (5) ECN-645484/B.K Everett, } \\
\text { 241-AY-02D Oiler Air Gap, } \\
\text { dated 7/7/98. } \\
\text { (6) ECN-649020/M.L. Alexander, } \\
\text { Tank Farm Ventilation Upgrade } \\
\text { W-030/CRI132, dated 6/29/98. } \\
\text { (1) HNF-IP-0842, Volume IV, } \\
\text { Engineering, Section 5.1, "Plant } \\
\text { Review Committee Charter } \\
\text { Procedure." } \\
\text { (2) PRC meeting minutes. } \\
\text { (3) RL Letter \#9850429 A, J.K. } \\
\text { McClusky to H.J. Hatch, } \\
\text { Contract Number } \\
\text { DE-AC06-96RL13200- } \\
\text { Recommendation for Declaring } \\
\text { an Unreviewed Safety Question } \\
\text { (USQ) Regarding Transfer } \\
\text { Structure Size Assumptions, } \\
\text { (1) }\end{array}$ \\
\hline
\end{tabular}


HNF-3314 REV 0

\begin{tabular}{|c|c|c|c|c|}
\hline Measurement Criteria & Met & $\begin{array}{l}\text { Not } \\
\text { Met }\end{array}$ & Examples & Documented Evidence \\
\hline $\begin{array}{l}\text { Project manager performance in } \\
\text { conducting projects - } \\
\text { Management and Control } \\
\text { (continued) }\end{array}$ & $X$ & & $\begin{array}{l}\text { Facilitated a change in strategy for the Organic } \\
\text { Safety Program that allowed for early closure } \\
\text { of the organic complexant USQ and safety } \\
\text { issue. } \\
\qquad \\
\text { An analysis framework was developed by a } \\
\text { team of flammable gas experts to quantify risk } \\
\text { and uncertainty of combustion accidents for } \\
\text { Hanford Site tanks and the change in risk from } \\
\text { applying different flammable gas control } \\
\text { strategies. A refined safety analysis will be } \\
\text { performed using the analysis framework for the } \\
\text { Hanford Site tanks to update the existing } \\
\text { TWRS Authorization Basis. } \\
\text { A strategy was developed to close the criticality } \\
\text { safety issue earlier than planned. }\end{array}$ & $\begin{array}{l}\text { dated January 16, } 1998 . \\
\text { (1) Completed sampling, analysis } \\
\text { and reporting activities as } \\
\text { requested by safety issues. } \\
\text { Resolution by July } 15,1998 \text {, to } \\
\text { support closure of the organic } \\
\text { complexant USQ. } \\
\text { (2) Letter, J.E. Meacham, DESH, to } \\
\text { W.E. Ross, LMHC, Organic } \\
\text { Safety Project: Completion of } \\
\text { Characterization to Support } \\
\text { Closure of the Organic } \\
\text { Complexant Unreviewed Safety } \\
\text { Question, DESH-9855539, dated } \\
\text { July 7, 1998. } \\
\text { Report HNF-SD-WM-ES-410, } \\
\text { Refined Safety Analysis } \\
\text { Methodology for Flammable Gas } \\
\text { Risk Assessment in Hanford Site } \\
\text { Tanks. }\end{array}$ \\
\hline
\end{tabular}


HNF-3314 REV 0

\begin{tabular}{|c|c|c|c|c|}
\hline Measurement Criteria & Met & $\begin{array}{l}\text { Not } \\
\text { Met }\end{array}$ & Examples & Documented Evidence \\
\hline $\begin{array}{l}\text { Project manager performance in } \\
\text { conducting projects - } \\
\text { Management and Control } \\
\text { (continued) }\end{array}$ & $\mathrm{X}$ & & $\begin{array}{l}\text { TW04 completed FY- } 98 \text { within the "L" Chart } \\
\text { thresholds for schedule and cost variances. }\end{array}$ & Year-end SV, CV variance charts. \\
\hline $\begin{array}{l}\text { Project manager performance in } \\
\text { conducting projects - } \\
\text { Technical Interface }\end{array}$ & $X$ & & $\begin{array}{l}\text { Successfully developed a vadose zone program } \\
\text { plan, which provides the basis of integrating the } \\
\text { vadose zone program with SST retrieval, tank } \\
\text { farm closure, interim storage and other } \\
\text { site-wide efforts. Successfully supported the } \\
\text { concerted effort between RL, Ecology, Oregon } \\
\text { Department of Energy, and Indian Tribal } \\
\text { Nations. } \\
\text { Established comprehensive agreement-in- } \\
\text { principle documents with Waste Management } \\
\text { Hanford and DynCorp to define roles and } \\
\text { responsibilities for privatization Phase 1B. } \\
\text { These documents have become models within } \\
\text { TWRS. } \\
\text { Completed TWRS projects ICD associated with } \\
\text { interfaces between W-519 and W-211, W-314, } \\
\text { W-464, W-465, and W-520. } \\
\text { Completed a memorandum of understanding } \\
\text { between W-464 and the SNF program to } \\
\text { facilitate project coordination. An artist's } \\
\text { rendering of the W-464 Storage Facility is } \\
\text { shown in Figure } 4.9-1 .\end{array}$ & $\begin{array}{l}\text { Letter, H.L. Boston, LMHC, to } \\
\text { A.M. Umek, FDH, Subcontract } \\
\text { Number } 80232764-9-\text { K001, } \\
\text { Transmittal of Tank Waste } \\
\text { Remediation System Vadose Zone } \\
\text { Program Plan, DOE/RL-98-49, } \\
\text { LMHC-9856254, dated } \\
\text { July 27, 1998. } \\
\text { Agreement-in-principle documents } \\
\text { dated July 31, 1998 are in process of } \\
\text { execution by WMH and DynCorp. } \\
\text { Issued as HNF-2588, ICD for TWRS } \\
\text { Privatization Phase 1 Infrastructure } \\
\text { Support Project W-519, Rev. 0, } \\
\text { dated April 23, 1998. } \\
\text { Letter, H.L. Boston, LMHC, to } \\
\text { A.M. Umek, FDH, Subcontract } \\
\text { Number } 80232764-9-\text { K001, W-464 } \\
\text { and W-379 Technical Integration, } \\
\text { LMHC 9855423, dated }\end{array}$ \\
\hline
\end{tabular}




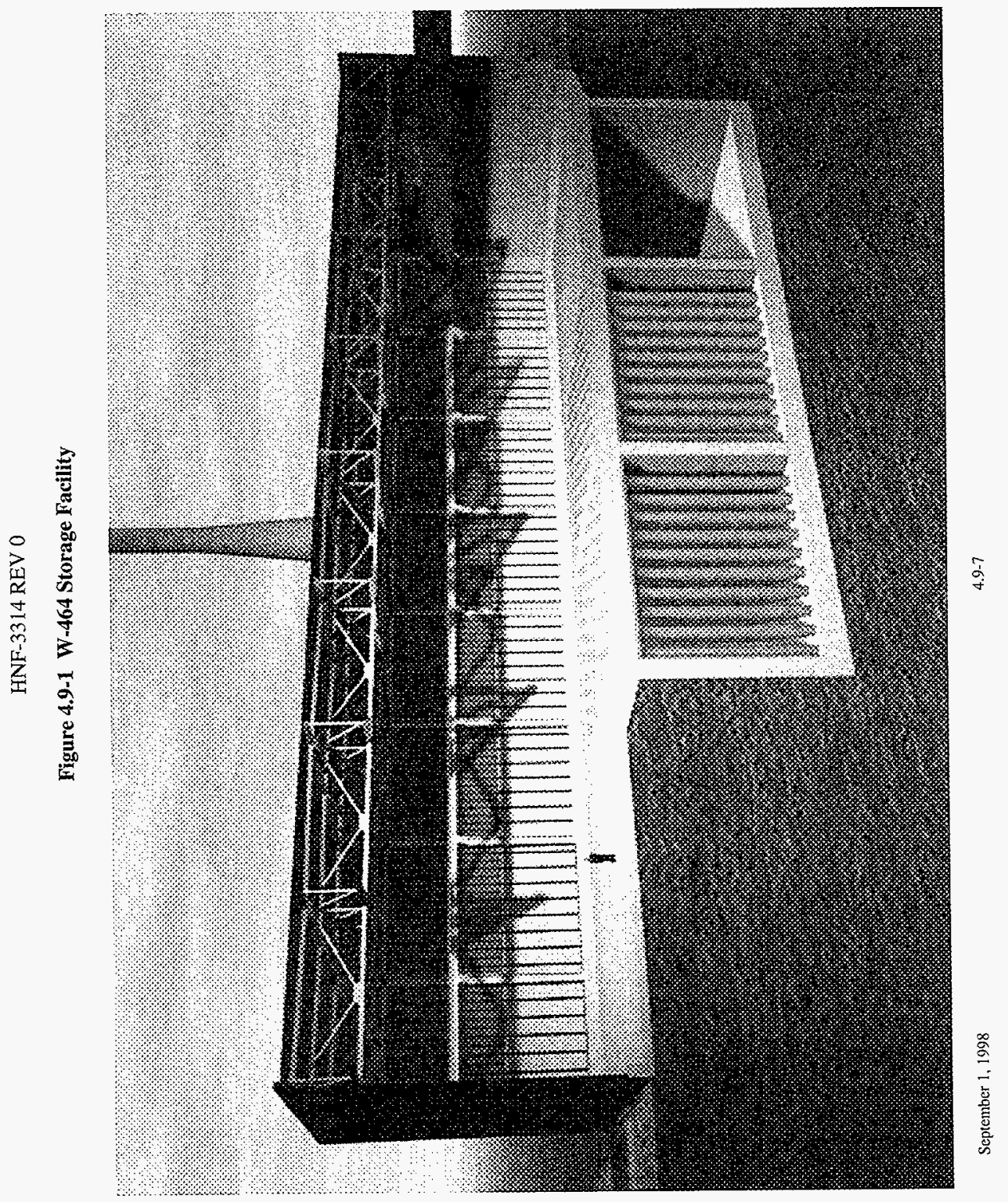




\begin{tabular}{|c|c|c|c|c|}
\hline Measurement Criteria & Met & $\begin{array}{l}\text { Not } \\
\text { Met }\end{array}$ & Examples & Documented Evidence \\
\hline $\begin{array}{l}\text { Project manager performance in } \\
\text { conducting projects - } \\
\text { Technical Interface (continued) }\end{array}$ & $\mathrm{X}$ & & $\begin{array}{l}\text { All interface control document (ICD) reviews } \\
\text { were conducted with trained and approved } \\
\text { personnel (regarding proprietary/business } \\
\text { sensitive information and organizational } \\
\text { conflicts of interest). Key staff were made } \\
\text { available to support this task while other } \\
\text { critically important activities such as readiness- } \\
\text { to-proceed and alternative case analyses were } \\
\text { being conducted. } \\
\text { Timely use of characterization data on tanks } \\
\text { AX-101 and SX-104 allowed for the movement } \\
\text { of the tanks to the appropriate flammable gas } \\
\text { facility groups and provided a basis for } \\
\text { evaluation of data against the Authorization } \\
\text { Basis. } \\
\text { Extensive efforts were completed to support } \\
\text { early closure of DNFSB 93-5 and } \\
\text { DNFSB } 92-4 \text {. A path forward was established } \\
\text { to effectively close the respective } \\
\text { recommendations. } \\
\text { Extensive work was performed in support of } \\
\text { the resolution of the high-heat safety issue for } \\
\text { waste tank } 241-C \text { - } 106 \text {. A report was developed } \\
\text { that describes the thermal hydraulic cormputer } \\
\text { models, the computer model benchmarking, }\end{array}$ & $\begin{array}{l}\text { Weekly report for week ending } \\
\text { 8/9/98. Refers to a presentation, } \\
\text { "Facility Groupings Associated with } \\
\text { Flammable Gas," prepared and } \\
\text { presented to DNFSB. } \\
\text { (1) DNFSB board meetings. } \\
\text { (2) Extensive communications with } \\
\text { the DNFSB board staff (weekly } \\
\text { telephone conversations, trips to } \\
\text { Washington D.C.). } \\
\text { Support for public meetings. } \\
\text { Technical report HNF-2152, } \\
\text { Thermal Hydraulic Computer } \\
\text { Models. }\end{array}$ \\
\hline
\end{tabular}


HNF-3314 REV 0

\begin{tabular}{|c|c|c|c|c|}
\hline Measurement Criteria & Met & $\begin{array}{l}\text { Not } \\
\text { Met }\end{array}$ & Examples & Documented Evidence \\
\hline $\begin{array}{l}\text { Project manager performance in } \\
\text { conducting projects - } \\
\text { Technical Interface (continued) }\end{array}$ & $\mathrm{X}$ & & $\begin{array}{l}\text { and methodology to be used in performing the } \\
\text { analysis necessary for resolution of the safety } \\
\text { issue. } \\
\text { Personnel in both the LHMC and Duke } \\
\text { Engineering criticality safety programs were } \\
\text { brought together organizationally and } \\
\text { physically to provide better coordination of } \\
\text { activities. } \\
\text { Effectively worked with National Laboratories } \\
\text { (PNNL, Los Alamos National Laboratory, and } \\
\text { Sandia National Laboratories) on technical } \\
\text { issues associated with the closure of the safety } \\
\text { issues for organic complexants, organic } \\
\text { solvents, and flammable gas. Technical reports } \\
\text { were prepared. In addition, several of these } \\
\text { reports will provide part of the technical bases } \\
\text { for the development of operational controls for } \\
\text { the tank farms. }\end{array}$ & $\begin{array}{l}\text { Internal Assessment Report, } \\
\text { Observation \#6.3.a. } \\
\\
\text { (1) Monthly reports, J.W. Brothers } \\
\text { (PNNL) to R.J. Cash (DESH), } \\
\text { PNNL Tank Waste Safety } \\
\text { Program Monthly Progress } \\
\text { Reports. } \\
\text { (2) LANL technical report, } \\
\text { Combustion within Porous } \\
\text { Waste, dated February } 23,1998 . \\
\text { (3) LANL technical report, Waste } \\
\text { Compatibility Criteria for } \\
\text { Preventing Flammable Gas } \\
\text { Hazards at the Hanford Site, } \\
\text { dated August 1998. } \\
\text { (4) Organic solvent topical report } \\
\text { closure package. } \\
\text { Working sessions continue with the } \\
\text { Ecology/RL/Contractor partnering } \\
\text { team for the development of the } \\
\text { FY 1999 Waste Information } \\
\text { Requirements Document (WIRD) to } \\
\text { meet Tri-Party Agreement }\end{array}$ \\
\hline
\end{tabular}


HNF-3314 REV 0

\begin{tabular}{|c|c|c|c|c|}
\hline Measurement Criteria & Met & $\begin{array}{l}\text { Not } \\
\text { Met }\end{array}$ & Examples & Documented Evidence \\
\hline $\begin{array}{l}\text { Project manager performance in } \\
\text { conducting projects - } \\
\text { Technical Interface (continued) }\end{array}$ & $X$ & 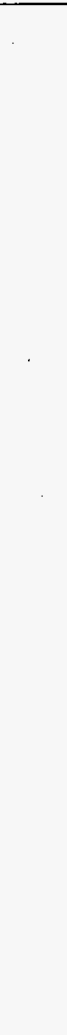 & $\begin{array}{l}\text { Conduct operations, laboratory, and technical } \\
\text { interfaces. }\end{array}$ & $\begin{array}{l}\text { commitments. Establishment of an } \\
\text { effective "change control/ } \\
\text { notification procedure" was } \\
\text { accomplished." } \\
\text { Support input for Tri-Party } \\
\text { Agreement commitments for } \\
\text { Interagency Management } \\
\text { Integration System meetings. } \\
\text { Provide support to Chemical } \\
\text { Reactions Sub-Tank Advisory Panel } \\
\text { as requested. } \\
\text { Provide Tier III review of SAD-035 } \\
\text { revision. } \\
\text { Provide facilitators for partnering } \\
\text { team meetings. } \\
\text { Maintain field sampling schedule, } \\
\text { sample analyses schedule, and } \\
\text { perform technical activities, } \\
\text { including the preparation and } \\
\text { issuance of DNFSB 93-5 quarterly } \\
\text { status reports; coordinate and } \\
\text { participate in DNFSB presentations, } \\
\text { support unit manager's meetings } \\
\text { and site management systems } \\
\text { reports; provide technical support to } \\
\text { RL/FDH. }\end{array}$ \\
\hline
\end{tabular}


HNF-3314 REV 0

\begin{tabular}{|c|c|c|c|c|}
\hline Measurement Criteria & Met & $\begin{array}{l}\text { Not } \\
\text { Met }\end{array}$ & Examples & Documented Evidence \\
\hline Quality of project reporting & $X$ & & $\begin{array}{l}\text { Well-documented quarterly reports were issued } \\
\text { that facilitated equipment improvements by } \\
\text { equipment engineering. These reports } \\
\text { documented performance metrics, equipment } \\
\text { changes, planned activities, and open issues. } \\
\text { All construction projects prepare monthly } \\
\text { reports addressing accomplishments, issues, } \\
\text { and cost and schedule performance. These } \\
\text { reports are.provided to RL two days in advance } \\
\text { of the scheduled management review meeting } \\
\text { and are the basis of the discussion at the } \\
\text { meetings. The reports are routinely completed } \\
\text { on time and provide accurate information } \\
\text { regarding project status. }\end{array}$ & $\begin{array}{l}\text { Monthly review meetings are } \\
\text { viewed as an efficient and effective } \\
\text { means of communication in } \\
\text { conveying project status. } \\
\text { (1) HNF-2060, Characterization } \\
\text { Engineering Status Report } \\
\text { October } 1997-\text { December } 1997 \text {, } \\
\text { dated February } 2,1998 . \\
\text { (2) HNF-2694, Characterization } \\
\text { Engineering Status Report } \\
\text { January } 1998 \text { - March } 1998, \\
\text { dated May } 8,1998 \\
\text { Management review reports }\end{array}$ \\
\hline $\begin{array}{l}\text { Cooperation of the project } \\
\text { manager in supporting the DOE } \\
\text { project manager }\end{array}$ & $\mathrm{X}$ & & $\begin{array}{l}\text { Project managers are very cooperative with } \\
\text { their customers and take a proactive approach } \\
\text { to project management and control. }\end{array}$ & $\begin{array}{l}\text { Monthly project reports to FDH. } \\
\text { Weekly interface meetings are held } \\
\text { to discuss overall status of project } \\
\text { work and any upcoming issues or }\end{array}$ \\
\hline
\end{tabular}


HNF-3314 REV 0

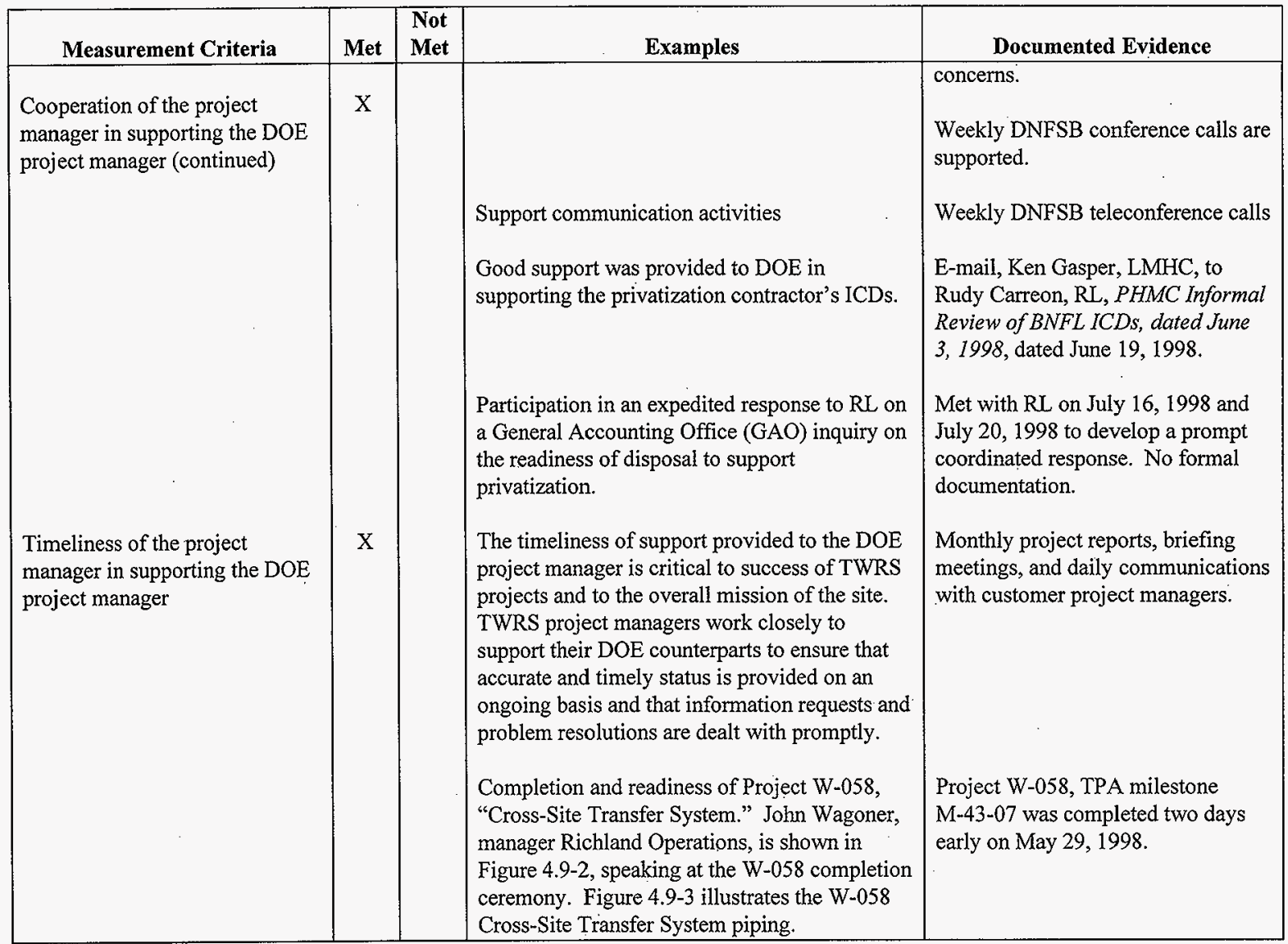


Figure 4.9-2 John Wagoner Speaking at the W-058 Completion Ceremony

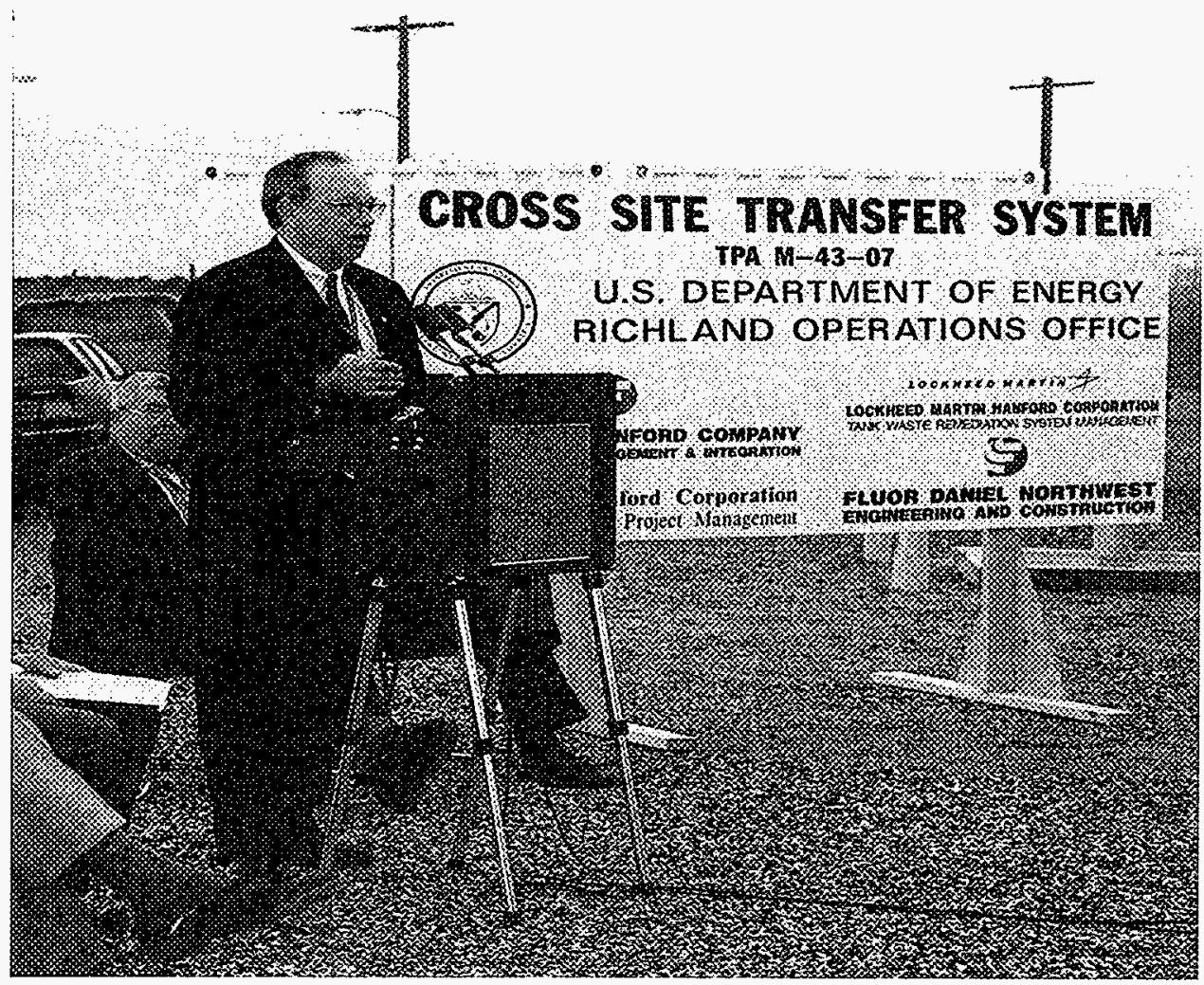




\section{Project W-058 Transfer Lines}

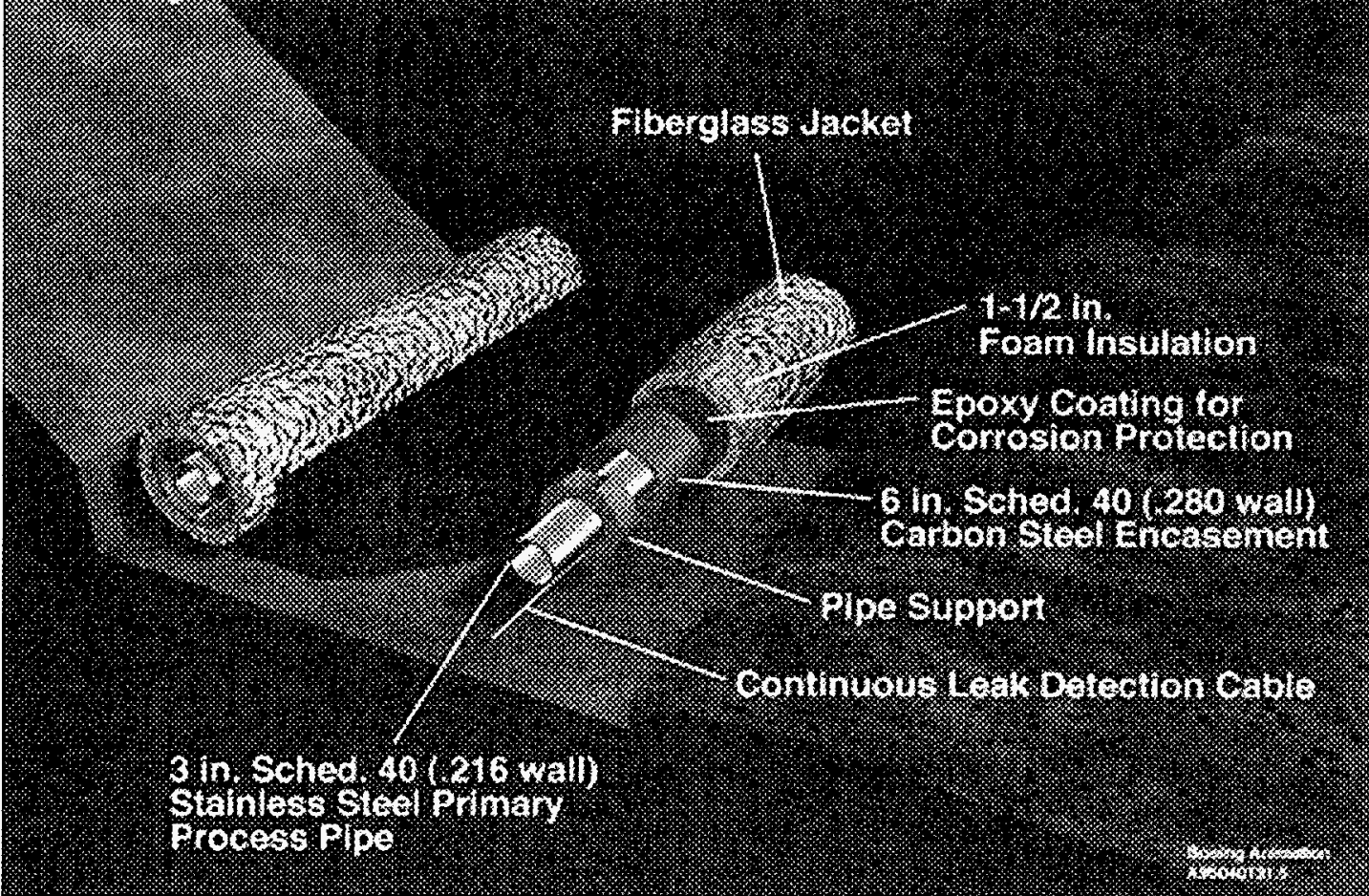


HNF-3314 REV 0

\begin{tabular}{|c|c|c|c|c|}
\hline Measurement Criteria & Met & $\begin{array}{l}\text { Not } \\
\text { Met }\end{array}$ & Examples & Documented Evidence \\
\hline $\begin{array}{l}\text { Timeliness of the project } \\
\text { manager in supporting the DOE } \\
\text { project manager (continued) }\end{array}$ & X & & $\begin{array}{l}\text { Two alternate case analyses were conducted } \\
\text { with a quick turn-around time in response to } \\
\text { RL project managers' need for information in } \\
\text { performing and conducting privatization } \\
\text { contract negotiations. Quality products were } \\
\text { delivered in a timely fashion with the RL } \\
\text { project manager kept abreast of the products as } \\
\text { they evolved. The RL project managers'. } \\
\text { comments, concerns, and general input were } \\
\text { addressed as the products were developed. } \\
\text { The SST mission analysis report was } \\
\text { successfully completed and transmitted to FDH } \\
\text { on August } 5,1998 \text {. The report was developed } \\
\text { in response to an RL request for an alternative } \\
\text { SST waste retrieval logic and scoping analysis } \\
\text { (mission analysis) driven by program needs } \\
\text { rather than by Tri-Party Agreement milestones. } \\
\text { The DST system specification development } \\
\text { effort encountered some miscommunication } \\
\text { and the early product did not meet RL } \\
\text { expectations. }\end{array}$ & $\begin{array}{l}\text { Letter, A.M. Umek, FDH, to W.J. } \\
\text { Taylor, RL, Contract Number } \\
\text { DE-AC06-96RL13200: Evaluation } \\
\text { of Tank Waste Disposal Alternative } \\
\text { Within Privatization, } \\
\text { FDH-985-02058A R1, dated } \\
\text { March 27, 1998. } \\
\text { Letter, A.M. Umek. FDH, to W.J. } \\
\text { Taylor, RL, Contract Number DE- } \\
\text { AC06-96RL13200: Evaluation of } \\
\text { Tank Waste Disposal Alternative } \\
\text { Within Privatization, FDH-9854671 } \\
\text { R1, dated June 15, 1998. } \\
\text { Letter, H. L. Boston, LMHC, to } \\
\text { A.M. Umek, FDH, Subcontract } \\
\text { Number 80232764-9-K001, } \\
\text { U.S. Department of Energy, } \\
\text { Richland Operations Office } \\
\text { Guidance for the Tank Waste } \\
\text { Remediation System Single Shell } \\
\text { Tank Retrieval Logic and Scoping } \\
\text { Analysis, LMHC-9761599A R3, } \\
\text { dated August 5, 1998. } \\
\text { Letter, H.L. Boston, LMHC, to } \\
\text { A.M. Umek, FDH, Subcontract } \\
\text { Number 80232764-9-K001; Defense } \\
\text { Nuclear Facility Safety Board }\end{array}$ \\
\hline
\end{tabular}


HNF-3314 REV 0

\begin{tabular}{|c|c|c|c|c|}
\hline Measurement Criteria & Met & $\begin{array}{l}\text { Not } \\
\text { Met }\end{array}$ & Examples & Documented Evidence \\
\hline $\begin{array}{l}\text { Timeliness of the project } \\
\text { manager in supporting the DOE } \\
\text { project manager (continued) }\end{array}$ & $X$ & & $\begin{array}{l}\text { BNFL treatability study waste liquids were } \\
\text { received from the Savannah River Technology } \\
\text { Center in a timely fashion, which prevented a } \\
\text { potential out-of-compliance situation at that } \\
\text { center. }\end{array}$ & $\begin{array}{l}\text { Recommendation 92-4, } \\
\text { Commitments 5.2.1.a and 5.2.1.b, } \\
\text { Technical Basis for Project W-211, } \\
\text { LMHC-9850-461 R2, dated } \\
\text { February 2, } 1998 . \\
\text { Letter, M.N. Roske, RL, to H.J. } \\
\text { Hatch, FDH, Contract No. DE- } \\
\text { AC06-96RL13200-Receipt of } \\
\text { Treatability Residues and Waste } \\
\text { Returns From BNFL Inc., } \\
\text { 98-WDD-044, dated } \\
\text { March 27, 1998. }\end{array}$ \\
\hline
\end{tabular}




\section{PHMC - Tank Waste Remediation System \\ Performance Expectation Plan \\ Self-Evaluation - Fiscal Year 1998}

4.10 Overall Performance Expectation: TWRS performance will be perceived by others as being good and getting better.

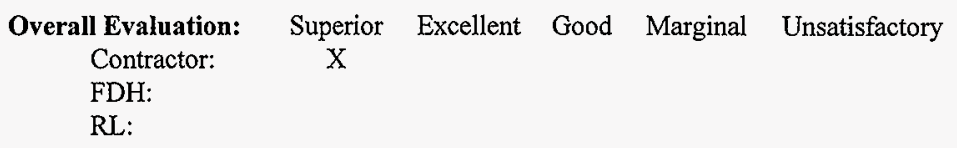

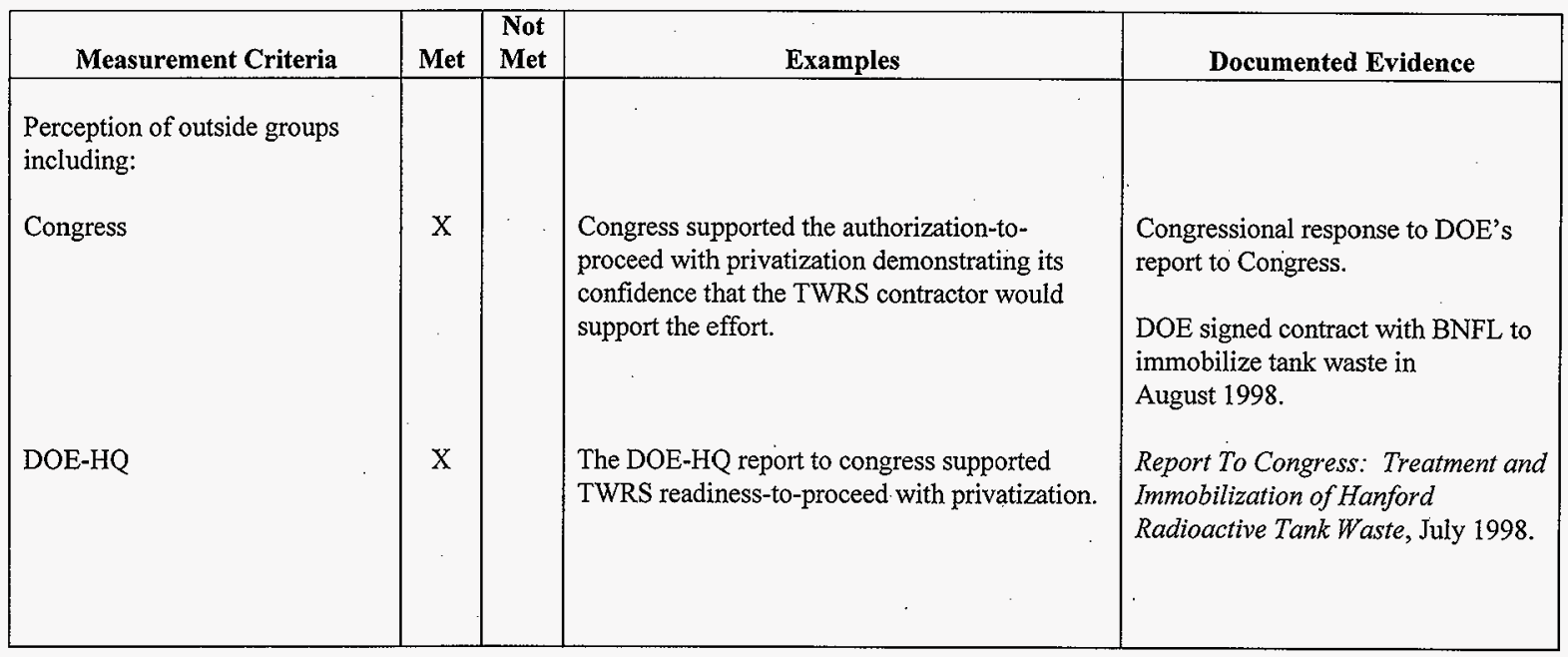


HNF-3314 REV 0

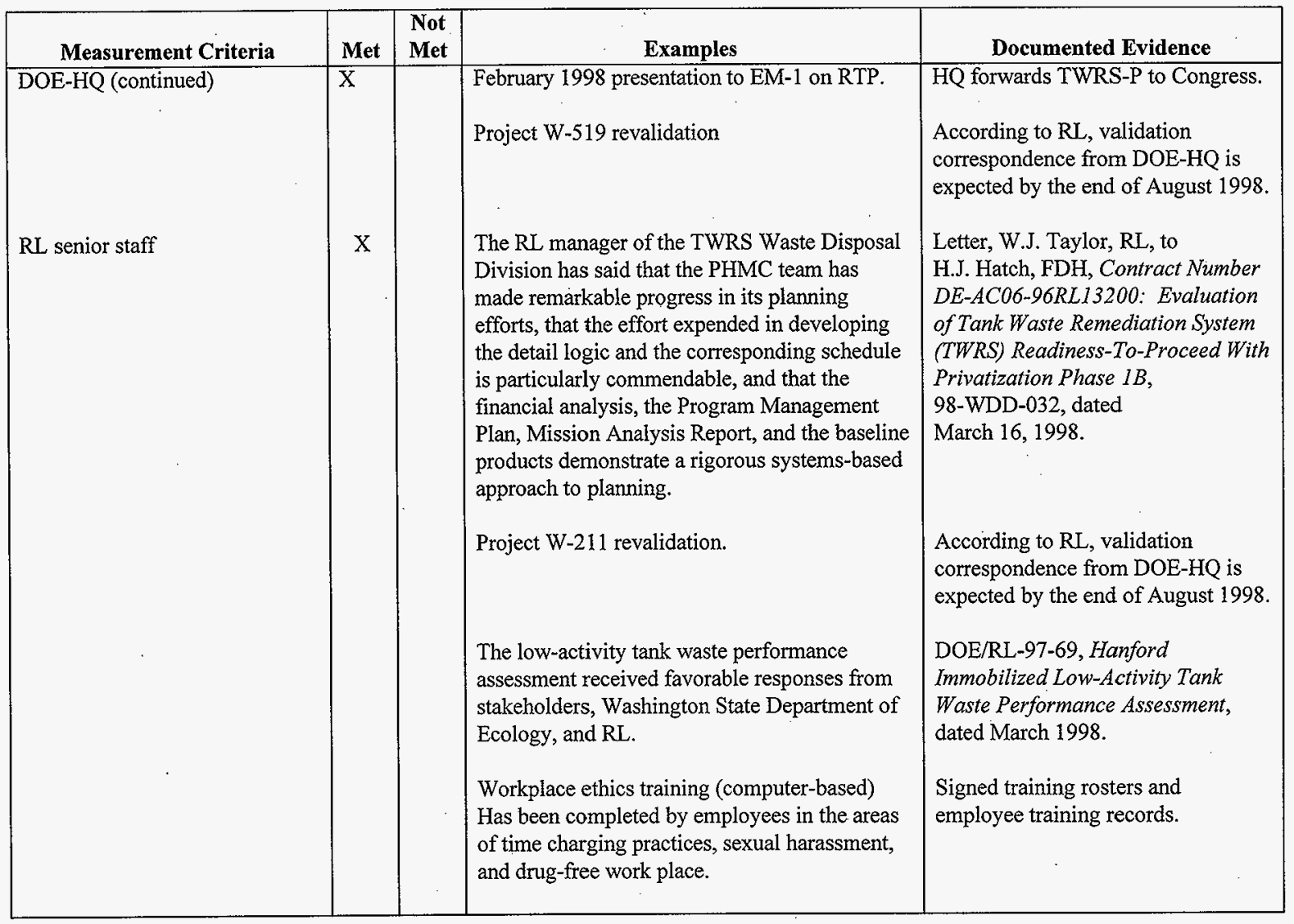


HNF-3314 REV 0

\begin{tabular}{|c|c|c|c|c|}
\hline Measurement Criteria & Met & $\begin{array}{l}\text { Not } \\
\text { Met }\end{array}$ & Examples & Documented Evidence \\
\hline RL senior staff (continued) & $\mathrm{X}$ & & $\begin{array}{l}\text { Hanford Data Integrator } 2000 \text { is being } \\
\text { proactively implemented as an improved } \\
\text { business tool. } \\
\text { Management Systems Project (MSP) has made } \\
\text { significant progress in instilling a system } \\
\text { engineering approach to planning (TBR } \\
\text { process), disciplined configuration management } \\
\text { plans, quality estimating, solid IPL } \\
\text { development, financial risk analysis to qualify } \\
\text { executability of plans, and drove } \\
\text { implementation of HANDI } 2000 \text { Business } \\
\text { Systems and Y2K critical system conversion. } \\
\text { Also developed defensible work management } \\
\text { business case. The DNFSB is also looking to } \\
\text { close } 92-4 \text { safety management findings. }\end{array}$ & $\begin{array}{l}\text { 1) Financial data, purchasing, and } \\
\text { human resources systems } \\
\text { replaced by commercial off-the- } \\
\text { shelf software } \\
\text { Peoplesoft/INDUS based on } \\
\text { systems October } 1,1998 \text {. } \\
\text { 2) Pentiums purchased to run } \\
\text { platform. } \\
\text { 3) Systems requirement } \\
\text { specifications documented. } \\
\text { 4) Power users trained by October. } \\
\text { 5) Procedure impacts analyzed. } \\
\text { 6) Source documents coded. } \\
\text { 7) Smooth fiscal year startup } \\
\text { accomplished. } \\
\text { TBR } 99 \text { planning. } \\
\text { Traceability of baseline changes. } \\
\text { IPL units of analysis. } \\
\text { RTP risk analysis. } \\
\text { Saltwell pumping risk analysis. }\end{array}$ \\
\hline
\end{tabular}


HNF-3314 REV 0

\begin{tabular}{|c|c|c|c|c|}
\hline Measurement Criteria & Met & $\begin{array}{l}\text { Not } \\
\text { Met }\end{array}$ & Examples & Documented Evidence \\
\hline $\begin{array}{l}\text { Washington Department of } \\
\text { Ecology }\end{array}$ & $\mathrm{X}$ & . & $\begin{array}{l}\text { Continued to support a successful partnering } \\
\text { team with the Washington State Department of } \\
\text { Ecology and with RL. } \\
\text { Successfully completed a state compliance } \\
\text { inspection on W-058; completed an operational } \\
\text { readiness review with no deficiencies. } \\
\text { The Washington State Department of Ecology } \\
\text { applauded DOE and its contractors for the } \\
\text { development of the TWRS program logic and } \\
\text { the disposal approach critical path. See } \\
\text { Figure } 4.10-1 \text {. Ecology viewed this logic as a } \\
\text { tremendous tool, and the critical path can see in } \\
\text { great detail what actions must occur to support } \\
\text { feed delivery and treatment plan, construction, } \\
\text { and operation. } \\
\text { Significant efforts were completed to assess the } \\
\text { chemicals within TWRS facilities following the } \\
\text { Plutonium Finishing Plant chemical occurrence. } \\
\text { All concerns were eliminated. }\end{array}$ & 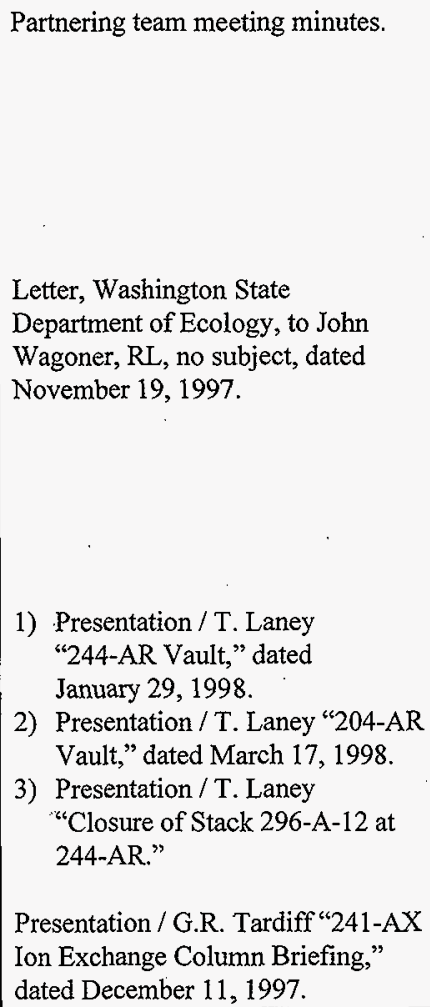 \\
\hline
\end{tabular}


Figure 4.10-1 Letter, WDOE to John Wagoner, RL, no subject, dated November 19, 1997

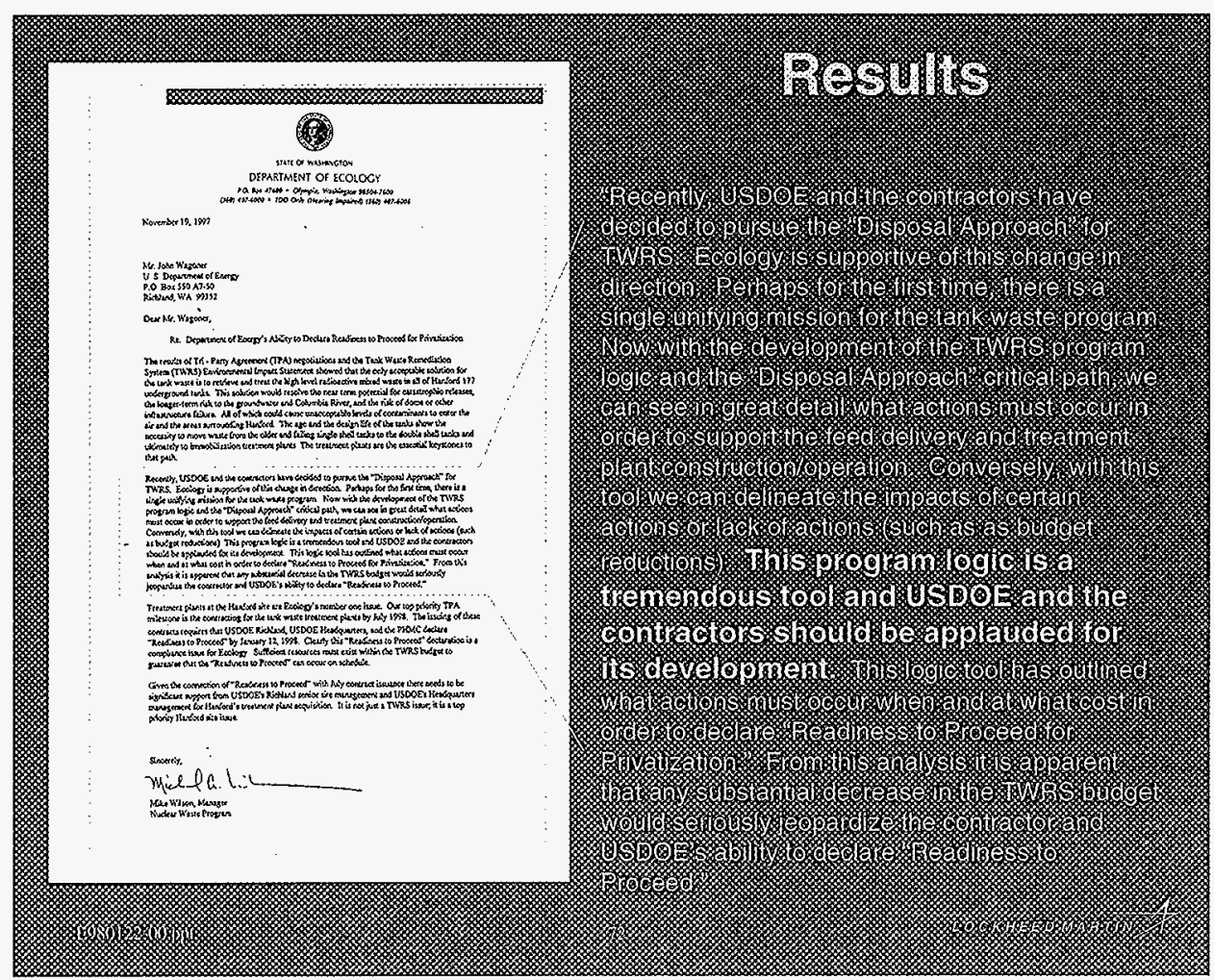


HNF-3314 REV 0

\begin{tabular}{|c|c|c|c|c|}
\hline Measurement Criteria & Met & $\begin{array}{l}\text { Not } \\
\text { Met }\end{array}$ & Examples & Documented Evidence \\
\hline $\begin{array}{l}\text { Washington Department of } \\
\text { Ecology (continued) }\end{array}$ & $\mathrm{X}$ & & $\begin{array}{l}\text { The ILAW and IHLW project management } \\
\text { plans were favorably received by the } \\
\text { Washington State Department of Ecology. } \\
\text { Participation in core team logic presentations. }\end{array}$ & $\begin{array}{l}\text { HNF-1751, TWRS Retrieval and } \\
\text { Disposal Mission, Immobilized } \\
\text { High-Level Waste Storage Plan, } \\
\text { Rev. 0, dated December } 1997 . \\
\text { HNF-1517, TWRS Retrieval and } \\
\text { Disposal Mission Immobilized Low- } \\
\text { Activity Waste Disposal Plan, } \\
\text { Rev. 0, dated December 1997. } \\
\text { Washington State Department of } \\
\text { Ecology letter on logic and } \\
\text { proceeding with retrieval path. }\end{array}$ \\
\hline Hanford Advisory Board & $\mathrm{X}$ & & $\begin{array}{l}\text { Support was provided for presentations to the } \\
\text { Hanford Advisory Board, Time Magazine, and } \\
\text { DNFSB to enhance the understanding of } \\
\text { TWRS. } \\
\text { Presented two-day briefing in March } 1998 \text { to } \\
\text { the Hanford Advisory Board on TWRS } \\
\text { operations and RTP, which was well received. } \\
\text { Similar presentation given to Oregon Waste } \\
\text { Board in April 1998. }\end{array}$ & $\begin{array}{l}\text { Hanford Advisory Board meetings } \\
\text { are supported on an "as needed" } \\
\text { basis. } \\
\text { Hanford Advisory Board } \\
\text { unanimously recommended to DOE } \\
\text { and Washington State Department } \\
\text { of Ecology to proceed with TWRS- } \\
\text { P based on Contractor performance } \\
\text { board letter on SE/Logic. }\end{array}$ \\
\hline DNFSB and stakeholders & $X$ & & $\begin{array}{l}\text { The DNFSB recognized the value of the TWRS } \\
\text { program logic and viewed this logic as } \\
\text { fundamental to the sound systems engineering }\end{array}$ & $\begin{array}{l}\text { Letter, J.T. Conway, DNFSB, to } \\
\text { F.F. Pena, DOE-HQ, no subject, } \\
\text { dated November } 12,1997 \text {. }\end{array}$ \\
\hline
\end{tabular}


HNF-3314 REV 0

\begin{tabular}{|c|c|c|c|c|}
\hline Measurement Criteria & Met & $\begin{array}{l}\text { Not } \\
\text { Met }\end{array}$ & Examples & Documented Evidence \\
\hline $\begin{array}{l}\text { DNFSB and stakeholders } \\
\text { (continued). }\end{array}$ & $X$ & & $\begin{array}{l}\text { management of the project. See Figure } 4.10-2 \text {. } \\
\text { DNFSB provided favorable comments to } \\
\text { W-465 as an example of the maturing of } \\
\text { systems engineering in TWRS. } \\
\text { DNFSB staff reviewed Project W-320, "Tank } \\
241-C-106 \text { Sluicing," in February } 1998 \text { and } \\
\text { July } 1998 \text { with no adverse findings. } \\
\text { Full board briefing in November } 1997 \text { on SE } \\
\text { and } 93-5-\text { well received. }\end{array}$ & $\begin{array}{l}\text { Letter, J. D. Wagoner, RL, to } \\
\text { J.T. Conway, DNFSB, DNFSB } \\
\text { Recommendation } 92-4 \\
\text { Implementation Plan, Revision } 2 N \text {, } \\
\text { Completion of Commitment } 5.2 .2(\mathrm{c}) \text {, } \\
\text { Evaluate } 1997 \text { Systems Engineering } \\
\text { Processes Existing on the TWRS } \\
\text { ILAW Interim Storage Project } \\
\text { (Project W-465), } 98 \text {-WDD-045, } \\
\text { dated April } 27,1998 \text {. } \\
\text { DNFSB internal meeting notes and } \\
\text { weekly reports. No formal } \\
\text { documentation. } \\
\text { SE/Logic presentation. }\end{array}$ \\
\hline
\end{tabular}









\section{PHMC - Tank Waste Remediation System \\ Performance Expectation Plan \\ Self-Evaluation - Fiscal Year 1998}

\subsection{Significant Evaluation Items}

4.11.1 Expectation: Issue a DOE reviewed and approved report on flammable gas issues in double-contained receiver tanks by June 23, 1998. This report is being prepared for the contractor by PNNL.

This report shall complete a technical basis document for the flammable gas issue related to DCRTs during saltwell pumping. It will include, for example, identification, understanding, validation, and quantification of gas carryover and release mechanisms for both dissolved and free gas; estimation of vapor-liquid equilibrium constants; identification, understanding, validation, and quantification of potential compatibility issues that could lead to gas generation; estimation of gas generation rates; simple dome space modeling to estimate resulting flammable gas concentrations; comparison to lower flammability limit estimates for mixtures of gases; and documentation sufficient to be a referenced document for safety issue resolution.

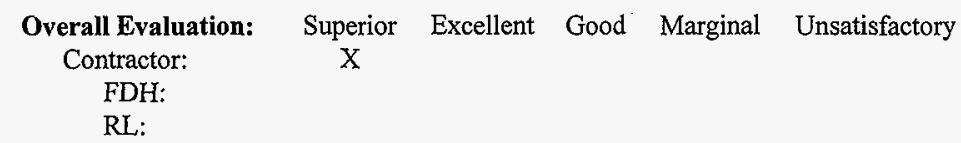

\begin{tabular}{|l|c|c|c|c|}
\hline \multicolumn{1}{|c|}{ Measurement Criteria } & Met & $\begin{array}{l}\text { Not } \\
\text { Met }\end{array}$ & \multicolumn{1}{c|}{ Examples } & Documented Evidence \\
\hline $\begin{array}{l}\text { Expectation will be met when a } \\
\text { final report, that has been } \\
\text { reviewed }\end{array}$ & $\mathrm{X}$ & & $\begin{array}{l}\text { The reviewed and finished report was submitted } \\
\text { on August 19, 1998. }\end{array}$ & $\begin{array}{l}\text { Due date moved to August 23, 1998 } \\
\text { by RL. Letter, M.N. Roske, RL, to } \\
\text { R.F. Green, FDH, Contract Number } \\
\text { DE }-A C 06-96 R L 13200-\text { Change in } \\
\text { Performance Evaluation Plan }\end{array}$ \\
\hline
\end{tabular}


HNF-3314 REV 0

\begin{tabular}{|c|c|c|c|c|}
\hline Measurement Criteria & Met & $\begin{array}{l}\text { Not } \\
\text { Met }\end{array}$ & Examples & Documented Evidence \\
\hline & & & & $\begin{array}{l}\text { Milestone Due Date for Flammable } \\
\text { Gas Issues in Double-Contained } \\
\text { Receiver Tanks, } 98-\text { SCD-079, } \\
9855413 \text {, dated June } 22,1998 \text {. }\end{array}$ \\
\hline Commented on by DOE & $\mathrm{X}$ & & Comments received $5 / 31 / 98$. & $\begin{array}{l}\text { Letter, C.L. Sohn, RL, to R.F. } \\
\text { Green, FDH, Contract Number } \\
\text { DE-AC06-96RL13200- Transmittal } \\
\text { of the U.S. Department of Energy, } \\
\text { Richland Operations Office (RL) } \\
\text { Review Comment Records on } \\
\text { Flammable Gas Issues in Double- } \\
\text { Contained Receiver Tanks, } 98-\mathrm{SCD}- \\
\text { 056, } 9854261 \mathrm{~A} \text {, dated May 13, } \\
\text { 1998. }\end{array}$ \\
\hline $\begin{array}{l}\text { Comments resolved, submitted } \\
\text { to DOE. } \\
\text { Time DOE will take to review } \\
\text { the document and method of } \\
\text { comment resolution shall be } \\
\text { agreed to by DOE and the } \\
\text { contractor }\end{array}$ & $\mathrm{X}$ & & & $\begin{array}{l}\text { Letter, A.M. Umek, FDH, to C.L. } \\
\text { Sohn, RL, Contract Number } \\
\text { DE-AC06-96RL13200-Tank Waste } \\
\text { Remediation System Performance } \\
\text { Expectation Plan, Significant } \\
\text { Evaluation Item (MEGA 4.11), } \\
\text { 'Issue a U.S. Department of Energy } \\
\text { Reviewed and Approved Report on } \\
\text { Flammable Gas Issues in Double- } \\
\text { Contained Receiver Tanks by June } \\
\text { 23, 1998', FDH 9856563A RL, } \\
\text { dated August 19, } 1998 .\end{array}$ \\
\hline
\end{tabular}




\section{PHMC - Tank Waste Remediation System \\ Performance Expectation Plan \\ Self-Evaluation - Fiscal Year 1998}

\subsection{Significant Evaluation Items}

4.11.2 Expectation: By July 1, 1998, provide U.S. Department of Energy (Richland Operations)-Tank Waste Remediation System with an interim stabilization program restructuring recommendation.

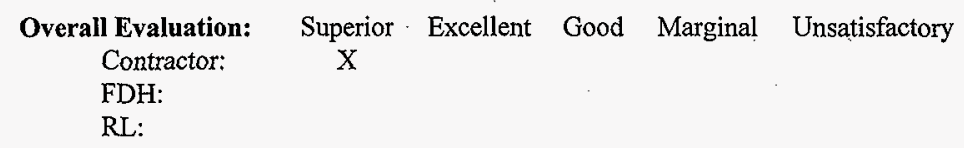

\begin{tabular}{|c|c|c|c|c|}
\hline Measurement Criteria & Met & $\begin{array}{l}\text { Not } \\
\text { Met }\end{array}$ & Examples & Documented Evidence \\
\hline $\begin{array}{l}\text { Enable completion of the } \\
\text { remaining TPA Milestone M-41 } \\
\text { scope of work } \\
\text { within the target total providec } \\
\text { or } \\
\text { within an optimized budget } \\
\text { and schedule profile that does } \\
\text { not exceed the baseline total, } \\
\text { commencing October } 1,1998 \text {. }\end{array}$ & $X$ & & $\begin{array}{l}\text { Single-Shell Tank Interim Stabilization Project } \\
\text { Plan, Rev. 1, issued May } 8,1998 \text {, presents a set } \\
\text { of assumptions and a funding scenario mutually } \\
\text { agreed to be the "most realistic and aggressive } \\
\text { plan for completing the stabilization program." }\end{array}$ & $\begin{array}{l}\text { Letter, D.I. Allen to A.M. Umek, } \\
\text { LHMC-9854008, dated May 14, } \\
1998 . \\
\text { Letter from FDH to RL. }\end{array}$ \\
\hline
\end{tabular}




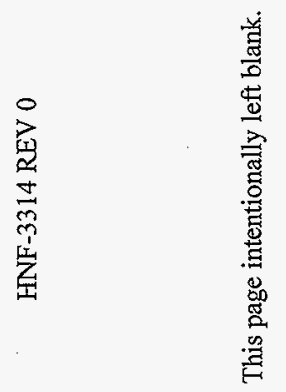




\section{PHMC - Tank Waste Remediation System \\ Performance Expectation Plan \\ Self-Evaluation - Fiscal Year 1998}

\subsection{Significant Evaluation Items}

\subsubsection{Expectation: By May 15, 1998, provide the proposed RL "Implementing Actions" list for RL approval.}

The interim stabilization program restructuring recommendation shall be supported by "Implementing Actions" lists for RL, the Contractor, and the Contractor subs, and a summary "Recommendation Basis" report that captures the operational constraints evaluated (for example, impacts on double-shell tank waste volumes) and provides the basis for the three implementing actions lists.

\section{Overall Evaluation: Superior Excellent Good Marginal Unsatisfactory \\ Contractor: \\ $\mathrm{X}$}

FDH:

RL:

\begin{tabular}{|l|c|c|l|l|}
\hline \multicolumn{1}{|c|}{ Measurement Criteria } & Met & $\begin{array}{l}\text { Not } \\
\text { Met }\end{array}$ & \multicolumn{1}{c|}{ Examples } & Documented Evidence \\
\hline $\begin{array}{l}\text { It is expected that the contractor } \\
\text { will perform a documented } \\
\text { analysis of the existing tank } \\
\text { farms practices used to interim } \\
\text { stabilize, and then isolate, } \\
\text { single-shell tanks that are } \\
\text { included within the scope of } \\
\begin{array}{l}\text { TPA Milestone M-41. } \\
\text { M. }\end{array}\end{array}$ & $\mathrm{X}$ & & $\begin{array}{l}\text { Single-Shell Tank Interim Stabilization Project } \\
\text { Plan, Rev, 1, issued on May 8, 1998. } \\
\text { Appendix B of Reference 2 of this project plan } \\
\text { lists the enabling assumptions, and } \\
\text { Attachment 2 of Reference 2 lists the critical } \\
\text { risk management list. This document provides } \\
\text { deliverables to this measurement criteria. }\end{array}$ & $\begin{array}{l}\text { Letter Allen to A.M. Umek, } \\
\text { LMHC-9854008, dated May 14, } \\
1998 .\end{array}$ \\
\hline
\end{tabular}


HNF-3314 REV 0

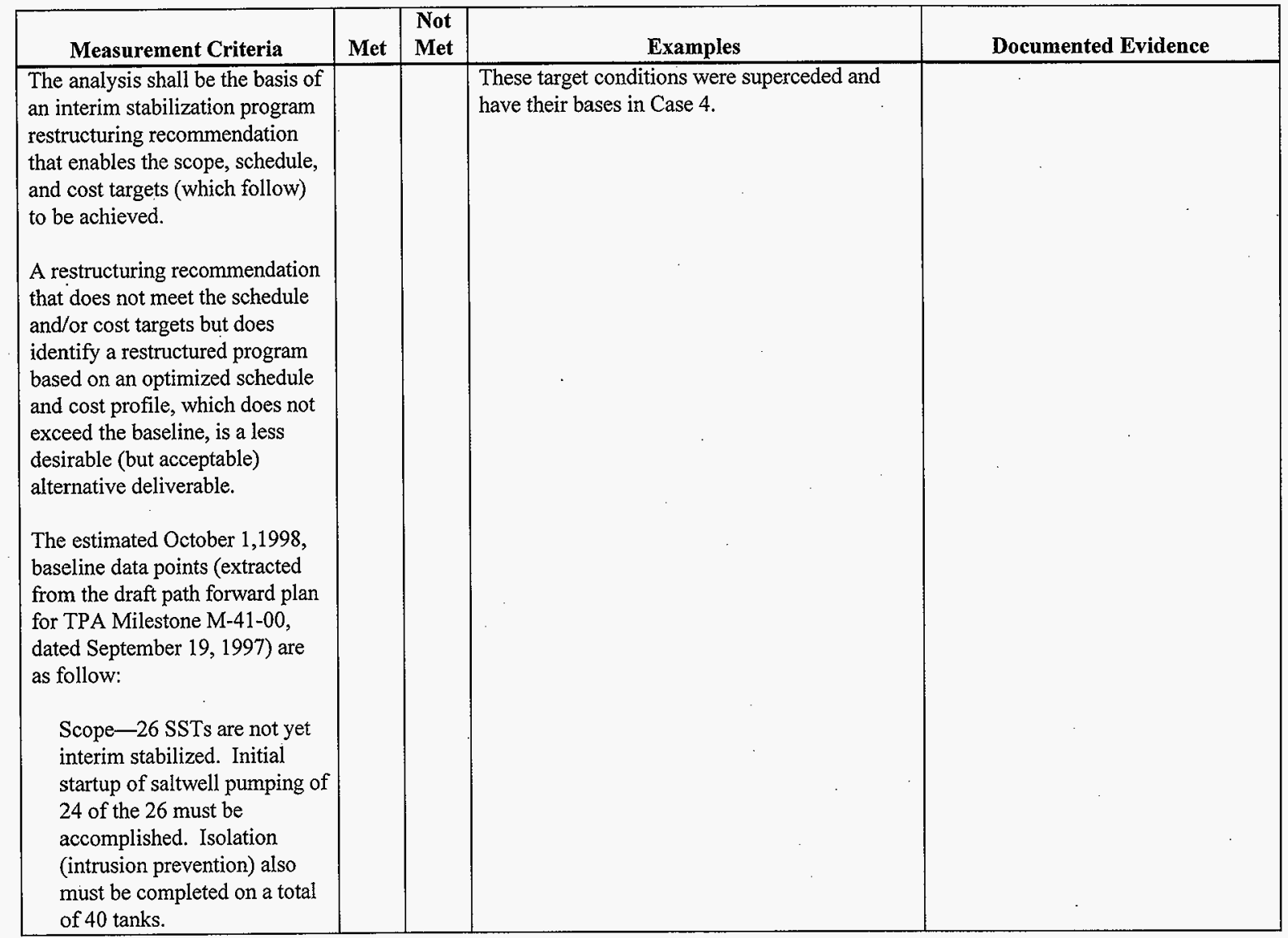




\begin{tabular}{|c|c|c|c|c|}
\hline Measurement Criteria & Met & $\begin{array}{l}\text { Not } \\
\text { Met }\end{array}$ & Examples & Documented Evidence \\
\hline $\begin{array}{l}\text { Schedule-Complete all of } \\
\text { the above scope (and the } \\
\text { FY } 98 \text { scope) by } \\
\text { September } 30,2003 \text {. }\end{array}$ & & & & \\
\hline $\begin{aligned} \text { Costs- } & \\
\text { FY-99 } & =10,692 \mathrm{~K} \\
\text { FY-00 } & =10,000 \mathrm{~K} \\
\text { FY-01 } & =10,000 \mathrm{~K} \\
\text { FY-02 } & =10,000 \mathrm{~K} \\
\text { FY-03 } & =5,000 \mathrm{~K}\end{aligned}$ & & & & \\
\hline $\begin{array}{l}\text { (10-1-98 Baseline) } \\
=45,692 \mathrm{~K}-4,692 \mathrm{~K} \\
\text { (reengineering efficiencies) } \\
\text { Baseline total = 41,000 K }\end{array}$ & & & & \\
\hline $\begin{array}{l}\text { Restructuring recommendation } \\
\text { target data (assuming } \\
\text { implementation on } \\
\text { October 1998) are as follow: }\end{array}$ & & & & \\
\hline $\begin{array}{l}\text { Scope-Identical to baseline } \\
\text { scope }\end{array}$ & & & & \\
\hline $\begin{array}{l}\text { Schedule-Identical to } \\
\text { baseline schedule }\end{array}$ & & & & \\
\hline $\begin{array}{l}\text { Costs-Not to exceed the per } \\
\text { year budgets in the baseline } \\
\text { and. }\end{array}$ & & & & \\
\hline
\end{tabular}


HNF-3314 REV 0

\begin{tabular}{|c|c|c|c|c|}
\hline Measurement Criteria & Met & $\begin{array}{l}\text { Not } \\
\text { Met }\end{array}$ & Examples & Documented Evidence \\
\hline $\begin{array}{l}\text { Initial startup }=700 \mathrm{~K} \\
\text { (average) } \times 24 \text { tanks } \\
=16,800 \mathrm{~K} \\
\text { Operate to completion } \\
=200 \mathrm{~K} \text { (average) } \times 26 \\
\text { tanks }=5,200 \mathrm{~K} \\
\text { Complete isolation }= \\
50 \mathrm{~K} \text { (average) } \times 40 \\
\text { tanks }=2,000 \mathrm{~K} \\
\text { All other costs }=250 \mathrm{~K} \\
\text { (average) } \times 40 \text { tanks }= \\
10,000 \mathrm{~K} \\
\text { Subtotal }=34,000 \mathrm{~K} \\
\text { Total additional capital } \\
\text { equipment not related to } \\
\text { construction = } 1,000 \mathrm{~K} \\
\text { (10-1-98 target total) }= \\
35,000 \mathrm{~K}\end{array}$ & . & & & . \\
\hline
\end{tabular}




\section{PHMC - Tank Waste Remediation System \\ Performance Expectation Plan \\ Self-Evaluation - Fiscal Year 1998}

\subsection{Significant Evaluation Items}

4.11.4 Expectation: By August 30, 1998, prepare and issue an annual operational waste volume projection report.

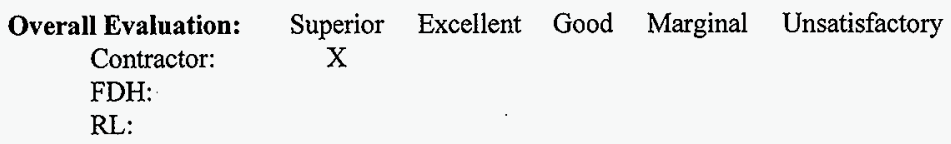

\begin{tabular}{|l|c|c|l|l|}
\hline \multicolumn{1}{|c|}{ Measurement Criteria } & Met & $\begin{array}{l}\text { Not } \\
\text { Met }\end{array}$ & \multicolumn{1}{|c|}{ Supporting Facts } & \multicolumn{1}{c|}{ Documented Evidence } \\
\hline $\begin{array}{l}\text { This report must be formally } \\
\text { submitted by FDH and received } \\
\text { by the appropriate RL TWRS } \\
\text { project manager by } \\
\text { August 30,1998. }\end{array}$ & $X$ & & $\begin{array}{l}\text { Report number HNF-IP-0842, Rev. 24, has } \\
\text { been completed. }\end{array}$ & $\begin{array}{l}\text { Report number HNF-IP-0842, } \\
\text { Rev. 24, issued in August 1998. }\end{array}$ \\
$\begin{array}{l}\text { Prior to formal submittal of the } \\
\text { report, all contractor reviews } \\
\text { shall have occurred and } \\
\text { comments shall have been } \\
\text { dispositioned. }\end{array}$ & $X$ & $\begin{array}{l}\text { Report was reviewed by all appropriate } \\
\text { contractor personnel and all comments were } \\
\text { dispositioned by July 31, 1998. }\end{array}$ & \\
\hline
\end{tabular}


HNF-3314 REV 0

\begin{tabular}{|c|c|c|c|c|}
\hline Measurement Criteria & Met & $\begin{array}{l}\text { Not } \\
\text { Met }\end{array}$ & Supporting Facts & Documented Evidence \\
\hline $\begin{array}{l}\text { Format and scope of the report } \\
\text { shall be similar to past OWVP } \\
\text { reports and shall include a } \\
\text { summary recommendation } \\
\text { regarding the construction of any } \\
\text { new double-shell storage tanks } \\
\text { and any appropriate measures to } \\
\text { take in the efficient management } \\
\text { of double-shell tank waste } \\
\text { volumes. }\end{array}$ & $X$ & & Format is the same as previous reports. & $\begin{array}{l}\text { Report number HNF-IP-0842, } \\
\text { Rev. 24, issued in August } 1998 .\end{array}$ \\
\hline $\begin{array}{l}\text { In addition, a special case shall } \\
\text { be provided in the report that } \\
\text { will identify the maximum } \\
\text { amount of single-shell tank } \\
\text { saltwell pumping activity that } \\
\text { can be conducted to ensure that } \\
\text { new tank capacity will not be } \\
\text { needed before FY } 2002 \text {. }\end{array}$ & $\mathrm{X}$ & & $\begin{array}{l}\text { Revision } 24 \text { of this report includes the base case } \\
\text { for the single-shell tank saltwell pumping } \\
\text { schedule. }\end{array}$ & $\begin{array}{l}\text { Report number HNF-IP-0842, } \\
\text { Rev. 24, issued in August } 1998 .\end{array}$ \\
\hline
\end{tabular}




\section{PHMC - Tank Waste Remediation System \\ Pexformance Expectation Plan \\ Fiscal Year 1998 \\ Self-Evaluation}

\subsection{Significant Evaluation Items}

\subsubsection{Expectation: By February 17, 1998, award tank C-106 heel removal contract.}

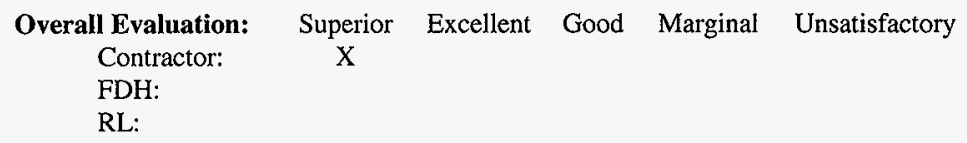

\begin{tabular}{|l|c|c|l|l|}
\hline \multicolumn{1}{|c|}{ Measurement Criteria } & Met & $\begin{array}{l}\text { Not } \\
\text { Met }\end{array}$ & \multicolumn{1}{c|}{ Supporting Facts } & \multicolumn{1}{c|}{ Documented Evidence } \\
\hline $\begin{array}{l}\text { Successfully complete all } \\
\text { activities necessary for } \\
\text { developing and issuing the } \\
\text { request-for-proposal package. }\end{array}$ & $\mathrm{X}$ & & $\begin{array}{l}\text { RFP issued on the Internet on August 6, 1997: } \\
\text { Solicitation No. WA31512. }\end{array}$ & $\begin{array}{l}\text { http://www.hanford.gov/tanks/ } \\
\text { hti/business/c106rfp/updates.htm }\end{array}$ \\
$\begin{array}{l}\text { Receive contractor bids } \\
\begin{array}{l}\text { Revicw and rank bids according } \\
\text { to established, technically } \\
\text { objective, metric criteria }\end{array}\end{array}$ & $\mathrm{X}$ & $\begin{array}{l}\text { Contractor bids received on October 8, 1997. } \\
\text { ranked the bids in accordance with the } \\
\text { established procurement procedure. }\end{array}$ & $\begin{array}{l}\text { Copies of the bids are not publicly } \\
\text { available. } \\
\text { Selection evaluation board } \\
\text { information is not publicly } \\
\text { available. }\end{array}$ \\
\hline
\end{tabular}


HNF-3314 REV 0

\begin{tabular}{|c|c|c|c|c|}
\hline Measurement Criteria & Met & $\begin{array}{l}\text { Not } \\
\text { Met }\end{array}$ & Supporting Facts & Documented Evidence \\
\hline $\begin{array}{l}\text { Award the contract to remove } \\
\text { tank } 241-\mathrm{C}-106 \text { residue wastes } \\
\text { that are expected to remain after } \\
\text { sluicing }\end{array}$ & $\mathrm{X}$ & & $\begin{array}{l}\text { Two contracts were awarded: } \\
\text { Foster Wheeler Environmental Inc. } \\
\text { Los Alamos Technical Associates }\end{array}$ & $\begin{array}{l}\text { Contract No. MSG-SBD-A42135 } \\
\text { Contract No. MSG-SBD-A42163 }\end{array}$ \\
\hline $\begin{array}{l}\text { Contractor shall provide RL } \\
\text { with a copy of official } \\
\text { documentation stating, at a } \\
\text { minimum, the award date and } \\
\text { the name of the contractor } \\
\text { receiving the award no later than } \\
\text { close of business Thursday, } \\
\text { February } 19,1998 \text {. }\end{array}$ & $\mathrm{X}$ & & $\begin{array}{l}\text { PHMC notified RL that the contracts were } \\
\text { awarded on February } 13,1998 .\end{array}$ & $\begin{array}{l}\text { Letter, A.M. Umek, FDH, to } \\
\text { W.J. Taylor, RL, Contract Number } \\
\text { DE-AC06-96RL13200; Tank Waste } \\
\text { Remediation System Performance } \\
\text { Expectation Plan Section 4.11, } \\
\text { Significant Objective Evaluation } \\
\text { Item (MEGA411**), By } \\
\text { February 17, } 1998 \text { Award Tank } \\
\text { C-106 Heel Removal Contract,' } \\
\text { Hanford Tanks Initiative, Milestone } \\
\text { Control Number T04-98-513, } \\
\text { FDH-9850892, dated February 18, } \\
\text { 1998. }\end{array}$ \\
\hline $\begin{array}{l}\text { Special note: If award exceeds } \\
\$ 10 M \text {, current contract precludes } \\
\text { FDH award of contract; in this } \\
\text { case, FDH shall recommend to } \\
\text { RL awardee by February } 17 \text {, } \\
1998 \text {. }\end{array}$ & & & & \\
\hline
\end{tabular}




\section{PHMC - Tank Waste Remediation System \\ Performance Expectation Plan \\ Self-Evaluation - Fiscal Year 1998}

\subsection{Significant Evaluation Items}

4.11.6 Expectation: By September 30, 1998, demonstrate 30-day single-shell tank emergency pumping preparation capability.

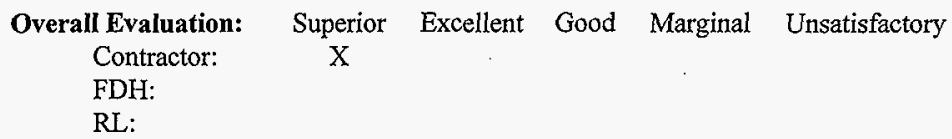

TW03 Operations

\begin{tabular}{|l|c|c|l|l|}
\hline \multicolumn{1}{|c|}{ Measurement Criteria } & Met & $\begin{array}{l}\text { Not } \\
\text { Met }\end{array}$ & Examples & Documented Evidence \\
\hline $\begin{array}{l}\text { Issue update to the Single-Shell } \\
\text { Tank Emergency Pumping } \\
\text { Guide by May 31, 1998 }\end{array}$ & $\mathrm{X}$ & & $\begin{array}{l}\text { The updated saltwell pumping guide was } \\
\text { released on May 20, 1998. }\end{array}$ & $\begin{array}{l}\text { Letter, D.I. Allen to A.M. Umek, } \\
\text { LMHC-9854430, dated May 28, } \\
1998 .\end{array}$ \\
$\begin{array}{l}\text { Complete a readiness assessment } \\
\text { confirming readiness for } \\
\text { pumping. }\end{array}$ & $\mathrm{X}$ & $\cdot$ & $\begin{array}{l}\text { Readiness assessment confirmed readiness to } \\
\text { emergency pump. }\end{array}$ & $\begin{array}{l}\text { Letter from fom } \\
\text { Letter from FDH to RL. }\end{array}$ \\
\hline
\end{tabular}




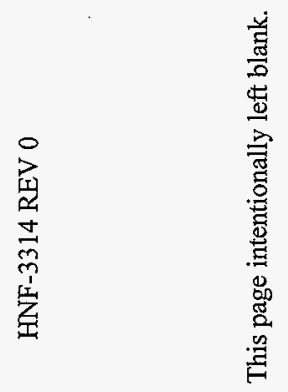




\section{PHMC - Tank Waste Remediation System \\ Performance Expectation Plan \\ Self-Evaluation - Fiscal Year 1998}

\subsection{Significant Evaluation Items}

4.11.7 Expectation: By August 30, 1998, complete installation and signal acquisition of Tank Monitoring and Control Systems on five tanks in AW Tank Farm (AW-102, AW-103, AW-104, AW-105, and AW-106).

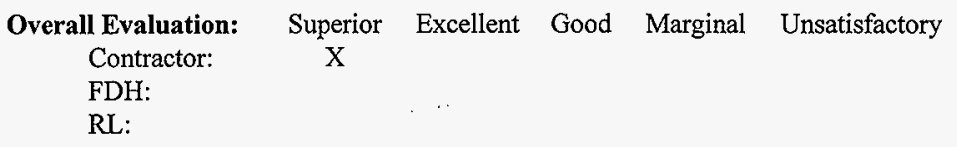

\begin{tabular}{|l|c|c|c|c|}
\hline \multicolumn{1}{|c|}{ Measurement Criteria } & Met & $\begin{array}{l}\text { Not } \\
\text { Met }\end{array}$ & \multicolumn{1}{c|}{ Supporting Facts } & Documented Evidence \\
\hline $\begin{array}{l}\text { AW-102 TMACS installation } \\
\text { and signal acquisition }\end{array}$ & $\mathrm{X}$ & & $\begin{array}{l}\text { Installed software on July 22, 1998, to receive } \\
\text { the signal. The ATPs for the installations in the } \\
\text { Measurement Criteria column will be } \\
\text { completed in August 1998. The expectation } \\
\text { will be met in September. } \\
\text { and signal acquisition }\end{array}$ & $\begin{array}{l}\text { Signals are being received in } \\
\text { TMACS control room. } \\
\text { A.M. Umek, FDH. } \\
\text { AW-104 TMACS installation } \\
\text { and signal acquisition }\end{array}$ \\
$\begin{array}{l}\text { AW-105 TMACS installation } \\
\text { and signal acquisition }\end{array}$ & & & & \\
\hline
\end{tabular}




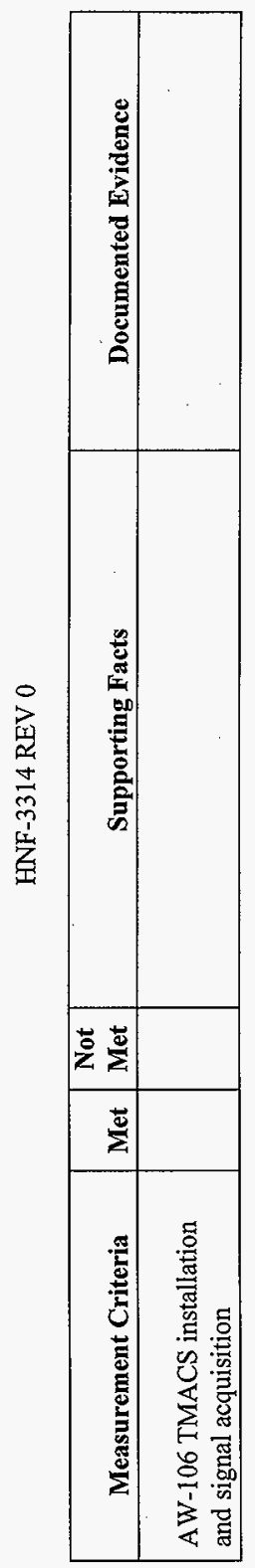

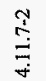

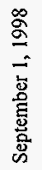


DISTRIBUTION SHEET

\begin{tabular}{|c|c|c|c|c|c|}
\hline To & \multirow{2}{*}{$\begin{array}{l}\text { From } \\
\text { TWRS CFO }\end{array}$} & & & \multicolumn{2}{|l|}{ Page 1 of 1} \\
\hline TWRS FDS Project Office & & & & \multicolumn{2}{|c|}{ Date $9 / 1 / 98$} \\
\hline \multirow{2}{*}{\multicolumn{4}{|c|}{$\begin{array}{l}\text { Project Title/Work Order } \\
\text { Tank Waste Remediation System }(H N F-3314)\end{array}$}} & \multicolumn{2}{|c|}{ EDT NNo. 625595} \\
\hline & & & & \multicolumn{2}{|l|}{ ECN No. } \\
\hline Name & MSIN & $\begin{array}{c}\text { Text } \\
\text { With Al1 } \\
\text { Attach. }\end{array}$ & $\begin{array}{l}\text { Text } \\
\text { On1y }\end{array}$ & \begin{tabular}{|} 
Attach. \\
$/$ \\
Appendi \\
$x$ \\
Only
\end{tabular} & $\begin{array}{l}\text { EDT/ECN } \\
\text { Only }\end{array}$ \\
\hline
\end{tabular}

L. E. HaTl

D. I. Allen

P. R. Angelier

H. L. Boston

M. P. Delozier

A. C. Etheridge

E. E. Mayer

S. J. Montgomery

M. A. Payne

P. E. Ray

A. M. Umek

R. F. Wood

M. D. Ebben

S. D. Brinkley

L. R. Dunbar

D. M. McDaniel

D. A. Raap

Central Files
H7- 07

R2. 50

57.82

R2. 53

R2.58

H7. 07

R2-50

S7. 81

R2-58

S7.80

$57 \cdot 40$

H7. 07

H7:07

H7- 07

H7.07

H7-06

S7-40

B1-07

$x$
$x$
$x$
$x$
$x$
$x$
$x$
$x$
$x$
$x$
$x$
$x$
$x$
$x$
$x$
$x$
$x$
$x$

